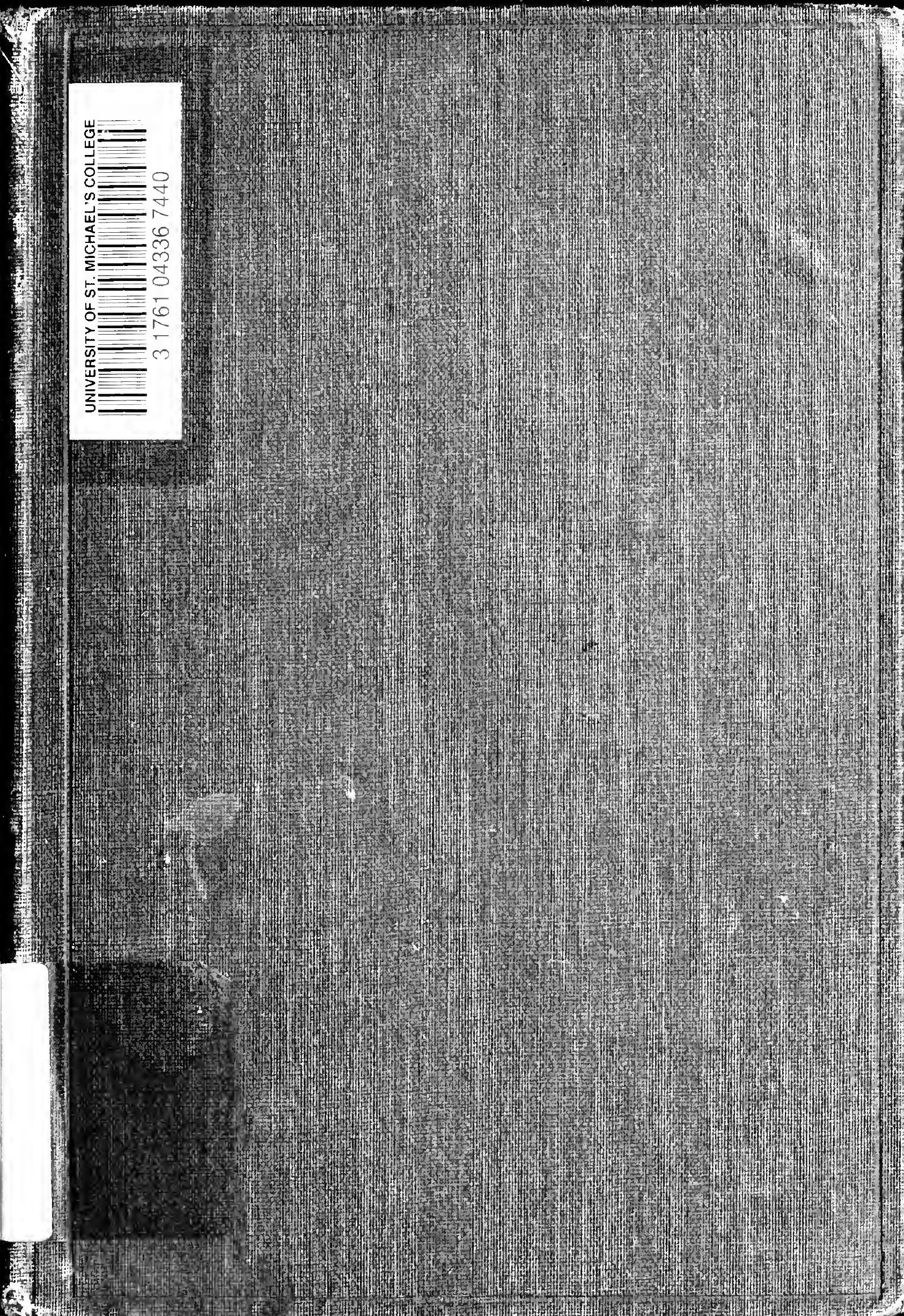


7.P / tarion. 
... 
Digitized by the Internet Archive in 2008 with funding from Microsoft Corporation 


\section{AN INTRODUCTION TO ECCLESIASTICAL LATIN}


Sola Scripturarum ars est, quam sibi passim vindicant:

Scribimus indocti doctique poemata passim.

Hanc garrula anus, hanc delirus senex, hanc sophista verbosus, hanc universi praesumunt, lacerant, docent, antequam discant. Alii, adducto supercilio, grandia verba trutinantes, inter mulierculas de sacris literis philosophantur.... Taceo de mei similibus, qui, si forte ad Scripturas sanctas post saeculares literas venerint, et sermone composito aurem populi mulserint, quidquid dixerint hoc legem Dei putant, nec scire dignantur quid prophetae, quid apostoli senserint: sed ad sensum sulım incongrua aptant testimonia....

Puerilia sunt haec et circulatorum ludo similia, docere quod ignores, imo, ut cum stomacho loquar, ne hoc quidem scire quod nescias.

Noli offendaris in Scripturis sanctis simplicitate et quasi vilitate verborum, quae vel vitio interpretum, vel de industria sic prolata sunt, ut rusticam concionem facilius instruerent, et in una eademque sententia aliter doctus, aliter audiret indoctus. Jerome, Ep. 53. * $\quad * \quad * \quad * \quad * \quad * \quad *$

Saepe et verba non latina dico ut intelligatis.

Angustine in Ps. 123.

* $\quad * \quad * \quad * \quad * \quad * \quad *$

Melius est reprehendant nos grammatici, quam non intelligant pop11li. Augustine in Ps. I.38. 


\section{AN INTRODUCTION}

\section{TO}

\section{ECCLESIASTICAL LATIN}

BY

Rev. H. P. V. NUNN, M.A.

ST JOHN'S COLLEGE, CAMBRIDGE

Author of The Elements of Nerv Testament Greek, A Short Syntax of New Testament Greek

Disce quod doceas. Jerome, Ep. ad Nepontiantm

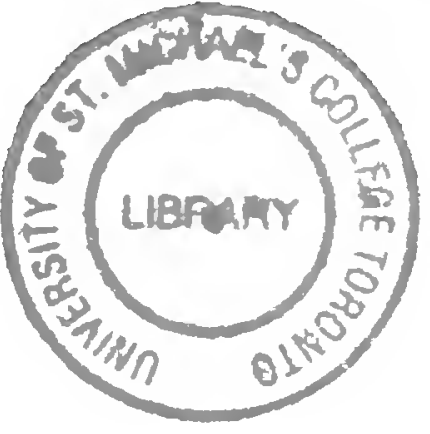

CAMBRIDGE

AT THE UNIVERSITY PRESS

I 922 
CAMBRIDGE. UNIVERSITY PRESS

C. F. CLAY, Manager

LONDON : FETTER LANE, E.C. +

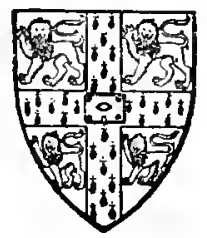

NEW YORK : THE MACMI LLAN CO. BOM BAY

$\left.\begin{array}{l}\text { CALCUTTA } \\ \text { MADRAS }\end{array}\right\}$ MACMILLAN AND CO., LTD.

'TORONTO : THE MACMILI,AN CO. OF CANADA, LTD.

TOKYO : MARUZEN-KABUSHIKI-KAISHA 


\section{MEMORIAE \\ MATRIS DILECTISSIMAE \\ IN CHRISTO DORMIENTIS}

DEDICATUM 


\section{CONTENTS}

THE ORIGIN AND CHARACTER OF ECCLESIASTICAL LATIN

\section{SYNTAX}

SENTENCES

NOUNS

PRONOUNS

VERBS

MOOD

TENSE

VOICE

THE IMPERATIVE MOOD: THE SUBJUNCTIVE MOOD IN PRINCIPAL CLAUSES . . . . 43

NOUN CLAUSES: . . . . . . . . . . . 46

THE DISTINCTION BETWEEN DIFFERENT SENSES OF THE

SAME WORD . . . . . . . . . . 46

The Infinitive Mood and its equivalents . • • 48

ThE INFINITIVE OR ITS EQUivalents USED AS THE SUB-

JECT OR COMPLEMENT OF A VERB • • • 54

The INFINITIVE OR ITS EQUIVALENTS USED TO COM-

PLETE THE MEANING OF CERTAIN VERBS • • 59

The Infinitive or its EQUIVAlents USED AS THE OB-

JECT OF A VERE . . . . . . . . 60

DePENDENT STATEMENTS . . . . . . 6 I

DEPENDENT COMMANDS . . . . . . . . 66

DEPENDENT QUESTIONS . . . . . . . .

NOUN CLAUSES IN APPOSITION TO A NOUN OR PRONOUN 69

ADJECTIVAL CLAUSES . . . . . . . 7 I

ADVERBIAL CLAUSES . . . . . . . . 74

Clauses of time $\quad . \quad$.

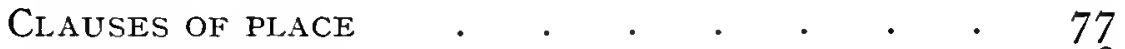

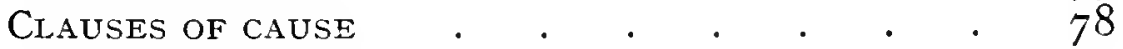

Clauses of PURPOSE 
ADVERBIAL CLAUSES (cont.)

Clauses of consequence . . . . . . . . 8 I

Clauses of CONCESsion . . . . . . . . 82

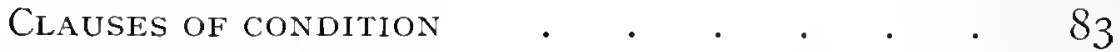

CLAUSES OF COMPARISON • .

PARTICIPLES . • . . . . . . . . . . 88

GERUND, GERUNDIVE AND SUPINE • • • • 92

QUESTIONS • • • . . . . . . . . . . . 97

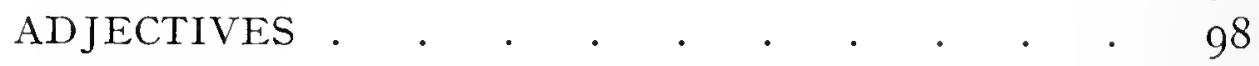

PREPOSITIONS . . . . . . . . . . IOO

EXTRACTS FROM ECCLESIASTICAL WRITERS

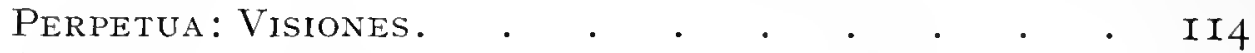

Cyprian: Jesus Christus patientiae exemplar • • It7

Quid est voluntas Dei? . . . . . . I I9

Quare Justus cun Christo esse Desiderat . II 9

DE DEFECTU FIDEI IN TRIBULATIONE • • I 20

Quod filit Dei Patri similes esse debent • I $2 \mathrm{I}$

Ambrose: De judicio Domini in Arianos . . . I 23

Jerome: Sominim Hieronymi . . . . . . I 26

DE VITA CLERICORUMI • • • • • • • . I 27

Augustine: De miserits Augustini in pueritia . . 132

Oratio pro Monnica matre sua . . . I34

Bede: Devita Beati Papae Gregorit . . . I36

De adventu Augustini ad praedicandum

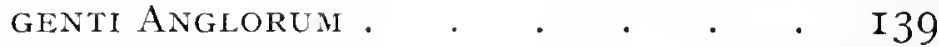

De colloguio Augustini cui episcopis Brittonum . . . . . . . . $\quad$ I 42

Adamnan: De vita et transitu ad Dominum Sancti Columbae . $\cdot$.

Thomas Aguinas: De bono fidei . • . . . $\quad$ I 49

DE FRUCTIBUS INCARNATIONIS . . I 52

QUARE ORARE DEBEMUS UT FIAT VOLUNTAS DEI . . . .

Thomas a Kempis: Qualiter homo desolatus se debet

IN MANUS DEI OFFERRE • . . 154

INDEX OF TEXTS QUOTED • • • • • • 157 


\section{PREFACE}

7 His book is written to meet the needs of a special class of 1 students, namely of those that desire to study Ecclesiastical Latin.

Ecclesiastical Latin may be defined as the form which the Latin language assumed in the hands of the Fathers of the Western Church and of their successors up to the time of the revival of learning.

The book is divided into two parts: first, a summary of such syntactical rules as are necessary for the understanding of the works of these writers, with an explanation of the points in which Ecclesiastical Latin differs from Classical Latin: secondly, a selection of passages taken from the works of some of the principal authors of the period with notes drawing the attention of the student to the appropriate sections of the syntax.

The syntax has been treated on broad lines, and no attempt has been made to trace all the peculiarities of the countless writers of Ecclesiastical Latin who represent so many different countries and degrees of culture.

The examples are taken as far as possible from the Vulgate New Testamert, because this is the most readily accessible book belonging to the period.

It must not be assumed from the fact that the examples are taken from this source that the Vulgate is to be regarded as typical of Ecclesiastical Latin.

It is a translation, and often a very literal translation, of a Hebrew or Greek original. The Vulgate is not a Latin Classic in the sense that the Authorised Version of the Bible is an English Classic.

It will however be found that most of the constructions that commonly occur in Ecclesiastical Latin are to be found in the Vulgate, and, generally spealing, examples have been given of these constructions only. A very slight attempt has been made to deal with the great variety of curious distortions of Latin which the translators made use of in the attempt to represent literally obscure passages in the Hebrew. 
Those who intend to use this book should possess at the least a knowledge of the conjugations of Latin verbs and the declensions of Latin nouns such as may be got from any primer ${ }^{1}$.

They should begin with the Vulgate New Testament which can be procured in the revised text of Wordsworth and White from the Bible Society. A brief dictionary of the Vulgate New Testament by Dr Harden has recently been published by the S.P.C.K.

From this they may pass on to the study of the easier Fathers, such as Cyprian, or to the Latin Hymns.

Unfortunately there are not many editions of the Latin Fathers readily accessible to English readers. The only collection of cheap texts is found in the series "Opuscula SS. Patrum," edited by H. Hurter at Innsbruck. The S.P.C.K. "Texts for Students" series contain some Latin texts.

The author intends shortly to publish a collection of Latin Hymns. At present the only one available is the "Hymni Latini," published by Clowes.

It is hoped that the book may be of use to ordination candidates; but there is also another class of student that the author had in mind when writing it, namely those who either begin the study of Latin after they leave school, or who wish to continue their study for the purpose of improving their education.

It is to be feared that not many persons carry away enough Latin with them from school to enable them to read the Classical authors with any readiness; to such persons who wish to improve their knowledge of the language by private study the author offers the following suggestions.

John Locke stated that in his opinion the best way for an adult to learn Latin was by reading the Latin Bible, and so great a linguistic genius as Lord Macaulay did not disdain to learn German from a German Bible. The author feels confident from experience that those who begin with the Latin Bible and the easier Ecclesiastical authors will be able to go on to the study of the Classics, if they desire to do so, with far more intelligence and profit than if they had tried to approach them without some previous preparation. He believes that, in the general absence of any opportunity of hearing spoken Latin and speaking the language oneself,

1 For beginners the author recommends Latin for Beginners, by Benjamin L. Dooge. Ginn and Co. Gradatim, by Heatley and Kingdon, is also useful. 
the next best course is to read as much as possible of such authors as are most easily understood $\mathbf{1}$.

The Gospels in the Vulgate are very simple and easy to understand, and the same simplicity of style is also found in some of the early Ecclesiastical writers and in many mediaeval writers, especially in the Hymns and Liturgies.

Speaking generally there is a directness and absence of artificiality about the Ecclesiastical writers which makes their works more easily intelligible than most of those of the Classical writers, except Caesar, and they have the advantage over his works in that they contain no long passages in "Oratio Obliqua."

Much of Classical Latin is highly artificial, not to say unnatural, in its modes of expression. The authors whose works are most generally read wrote for a fastidious and highly cultivated society of littérateurs who, in most cases, thought far more of style than of matter. Their subject matter was often borrowed from the Greek; they wrote rather to please than to instruct; and, especially under the early Empire, they wrote with a view to reading their works to admiring circles of friends, whose applatuse they hoped to arouse by some novel or far-fetched tirin of expression. All Classical Latin literature, except the very best, is vitiated by rhetoric, and by the desire to say old things in a new way.

The Christian authors, on the other hand, although most of them had been trained in the rhetorical schools, and although their writings show many traces of their training, were at least men in

1 The author is pleased to find that his opinion in this matter is confirmed by the high authority of the late Dr J. H. Moulton in the parallel case of an adult who wishes to learn Greek.

Dr Moulton considers that this study may be most easily approached by the way of N.T. and Hellenistic Greek, which, in Latin, is paralleled by the Vulgate and the Ecclesiastical writers.

Dr Moulton's words are as follows:

"Men who have had no educational advantages, called to the work (of the ministry) after many years away from school-how shall we best train them for service in which experience shows they may be surpassingly useful? . . Perliaps the writer may contribute his experience of some years. Hellenistic Greek proves a far shorter road than the Classical grammar which the writer used in his schoolmaster days. A short and simple grammar and reader in New Testament Greek, written for the purpose, supplies the forms and syntax needed for intelligent reading of the sacred text; and with this basis it is found that students with an aptitude for languages can go on to Classical Greek when they have becone proficient in the far easier Hellenistic." J. H. Moulton in Camb. Biblical Essays. 
deadly earnest. They did not write to amuse the leisure of their friends: those of the first three centuries wrote with the fear of death always hanging over them to men who needed help and guidance in the face of the same terror: those belonging to the age after the triumph of the Church wrote of things which they held to be of eternal and sovereign importance both to themselves and to those who should read their books. This, generally speaking, gives their writings a simplicity and directness which greatly facilitates the progress of the learner.

Even the Latin of the middle ages, although it is certainly not Ciceronian, and would not have passed current even with Jerome, yet is a wonderfully forcible and pregnant form of speech at its best.

It is foolish to condemn and neglect a whole period of literature, because the style in which it is written does not come up to a purely artificial and arbitrary literary standard.

It is not necessary to deny the great excellence of the Latin of the Augustan age, and of Cicero in particular, in order to see merits in the Latin of other periods. We may heartily agree that the Latin of the Golden Age is supreme and unapproachable. We may all wish to write like Cicero and do our best to imitate him; but this is no reason why we should refuse to see any merit in writers who, carried on by the natural development of the language, and.by the strange and novel ideas which they were constrained to express, wrote in a different style, and with a different vocabulary.

There is no more reason for setting up the writers of the Augustan age as models of style, and labelling all that does not conform to their standard as decadent or barbarous, than there would be for setting up Dryden, Pope and Johnson as the only correct writers of English. No language in which it is still possible for an author to express his thoughts with precision and clearness can justly be called decadent or barbarous, even though it does not conform to a given standard; and it is by this test, rather than by approximation to any "Classical" style, that the later authors should be judged.

Although, as has been said, much of the work of the earlier Ecclesiastical authors is vitiated by the rhetorical devices common to the period in which they lived, and although many of the later authors are barbarous enough; yet, with few exceptions, all the 


\section{Preface}

best known writings of Ecclesiastical authors of the first rank are worth studying in the original.

There are very few books accessible on this subject. The following have been consulted:

Goelzer. La Latinité de St Jérôme (deals with Jerome's writings other than the $\mathrm{Vg}$.).

REgnier. La Latinité des sermons de St Augustin.

Kaulen. Sprachliches Handbuch zur Biblischen Vulgata. (New edition, Freiburg im Breisgau r904.)

Roensch. Itala und Vulgata.

Dalpane. Nuovo Lessico della Bibbia Volgata (Firenze I9I I).

Peultier, Etienne, Gantois. Concordantiarum universae Scripturae Sanctae Thesaurus. Paris.

None of these books except the first and the last are very helpful.

The author wishes to thank Dr H. J. White, Dean of Christ Church, for kind advice and encouragement.

$$
\text { H.P.V.N. }
$$

THORNCLIFFE,

Clifton Road,

Heaton Moor, Stockport

November I $92 \mathrm{I}$ 



\section{THE ORIGIN AND CHARACTER OF ECCLESIASTICAL LATIN}

$\mathrm{T}$ HE basis, and much of the content, of Ecclesiastical Latin is to be found in the vernacular speech of the Roman people of which but little survives in literature.

The form of Latin which is most commonly studied is that which is to be found in the writings of the great authors who lived in the century before the commencement of the Christian era. To this form of the langnage the name 'Classical' has been given, and it is often referred to as the Latin of the Golden Age.

All the books of this period that have come down to us were the work of highly trained literary men who were thoroughly acquainted with Greek literature and who imitated of set purpose not only its form, but also its content.

Vos exemplaria Graeca

Nocturna versate manu, versate diurna,

was the maxim which all of them followed.

The consequence of this is that 'Classical Latin' is, speaking generally, a very artificial form of language. It may be said of it, as has been said of Attic Greek (as portrayed in the literature of Athens), that it is an artistic language which nobody ever spoke, but which everybody understood.

This form of the langtuage, however, was regarded in ancient, no less than in modern times, as an example to be followed, as far as possible. 'The writings of Cicero, Vergil, Horace and Ovid were studied in the schools of the Roman Empire in Africa, Gaul and Spain, no less than in Italy, as models of style and vocabulary, and left an ineffaceable mark on the language. They continued to be studied, though with less zeal and intelligence, throughout many periods in the middle ages and at the Renaissance they came in for more than their own.

To write like Cicero or Vergil became the passionate desire of all scholars and the chief end of education : the direction then given to literary study has influenced the course of teaching almost to the present day. 
In spite of the protests of Erasmus, style was set up as the end after which the scliolar must strive, and that a style not his own, but a style initated from great writers who lived nearly two thousand years ago under quite a different civilization, and in another sphere of thought. The skill most commended was that which caught some trick of phrase and adapted it to the translation of contemporary forms of expression. It was this 'Ciceronianism,' as it has been called, that did so mnch to kill Latin as a living language, because it checked all spontaneity and preferred to galvanize a corpse rather than to encourage the growth of a living organism.

During the time when the Classical literature was growing into perfection and passing into the stage of imitation and decay the Vernacular Latin also continued to grow and, like all growing organisms, to absorb many elements from its surroundings.

Those who spoke it were not deterred by any fear of the schoolmaster or the audiences in the recitation rooms from adding new words when they were required to express new ideas.

The genins of the old Latin language, like that of the old Roman people, expressed itself in action and was rich only in verbs and in concrete terms. Abstract ideas were quite foreign to native Latin thought, and, when the introduction of Greek philosophy rendered it necessary to express such ideas in speech, recourse was had either to a periphrasis or to new-coined or adopted words.

Substantives ending in io, $i a$ and tas began to increase in number and also adjectives in is; but the Classical writers avoided these new methods of expression as far as possible, or introdnced them with an apology. It was not until the old Latin families liad been killed off in the civil wars, until Greek became the language of all educated men in Rome and the most celebrated Latin authors began to arise, not in Italy, but in Spain and Africa, that the boundaries of the old Latin speech were gradually broken down, and a flood of new words and constructions, mostly borrowed from Greek, or suggested by it, mingled with the stately current of the ancient diction. Such words as essentia, substantia, personalis, possibilis then came into 11se, all, be it noted, words that have passed into English. The Latin language ceased to be the language of a nation and became the language of an empire.

It was just about this period that Ecclesiastical Latin came into existence. 


\section{of Ecclesiastical Latin}

The language in which the Christian writers first wrote was, of course, Greek. Greek, thanks to the conquests of Alexander, was the lingua franca of the East where Christianity took its origin.

When St Paul wished to write to the Church in Rome, he wrote in Greek. When St Clement (a Roman Bishop) wrote to Corinth he also wrote in Greek. Nany of the earliest inscriptions in the Catacombs are in Greek. Latin does not seem to have been commonly used in the Roman Church until the end of the second century $\mathbf{1}^{\mathbf{c}}$.

It was not for Rome that a Latin translation of the Bible was needed, but for Africa, Gaul and Spain, and perhaps for the country congregations of Italy.

The first Christian writing in Latin of which we have any knowledge is this Latin version of the Bible. It is commonly known as the Old Latin version and will be referred to here by the abbreviation O.L. It is not known with any certainty by whom or when this translation was made. It seems to have been a composite work made by several hands, perhaps at different periods. It had one marked peculiarity: it was an extremely literal translation.

"We have already said," writes Gaston Boissier, "that the first persons who translated the Holy Scriptures into Latin were not professional authors, but only scrupulous Christians who desired no other merit except that of being faithful interpreters. Preoccupied before all things with the object of basing their version on the text, they created new words, invented strange expressions, and tortured the ancient language without pity, to make it fit the genius of a foreign idiom. Can anyone imagine what an admirer of Vergil or a pupil of Cicero must have had to suffer when thrown into the middle of this barbarism 2 ?"

At the beginning of the third century we find that a generally received translation of the Bible was coming into use at Carthage, and by the middle of the century it was quite established.

This translation underwent many revisions. A rather smoother version circulated in Italy and Gaul: another, still more refined, was used by St Angustine in the fourth and fifth century, and this is sometimes called the Itala.

The first of these versions is found in the writings of Cyprian and in the Codex Bobbiensis. The second is found in the Codex

1 See Sanday and Headlam, Romans, p. lii.

2 La Fin de Paganisme, vol. 1, p. 35I. 
Veronensis. The third is found in the writings of Augustine and in the Codex Brixianus.

In these versions the translation of the O.T. was made from the Greek version known as the Septuagint (commonly called the IXX) which was accepted by the early Church as quite as authoritative as the Hebrew original which few Christians could read. This LXX version was also a very literal translation of the Hebrew, literal to the verge of unintelligibility in many places, especially in the poetical and prophetic books.

Thus the O.L. version of the O.T. was the literal translation of a literal Greek translation of a Hebrew original, and it is not wonderful if not only the beauty, but also the sense, of the original often disappeared under such handling.

The O.L. version of the N.T. was made from the Greek original. Anyone who wishes to see how literal it is may compare the Latin version of the Epistle to the Ephesians with the Greek original and then with Beza's version.

The most potent influences in the formation of early Ecclesiastical Latin were (I) the Vernacular Latin of the period, by which the Fathers allowed themselves to be influenced in order that they might be understood by half-educated people, (2) the O.L. version of the Bible with its many Graecisms and Hebraisms, (3) the Classical Latin as taught in the schools, of which all the Fathers were pupils, or even teachers.

We might perhaps add a fourth source of influence to the above, namely the writings of Tertullian, who was an author of a very original and independent type of genius and who had great influence on all his Christian successors, especially on Cyprian.

The O.L. version of the Bible did not however influence later Ecclesiastical Latin directly.

The text got into such a bad condition at the end of the fourth century that Pope Damasus commissioned the most famous scholar of the day to re-edit it.

This man Eusebius Hieronymus, or Jerome, as he is commonly called, had studied Latin in Rome under Donatus, was well acquainted with Greek and had some knowledge of Hebrew. When he set to work on the task imposed on him by Pope Damasus he found that the translation of the O.T. was so incorrect and corrupt that nothing but a complete retranslation of the whole from the Hebrew could produce a satisfactory result. He therefore set him- 


\section{of Ecclesiastical Latin}

self to improve his knowledge of Hebrew and, in the face of great opposition and much prejudice, he retranslated the whole of the O.T. from the Hebrew original. But in so doing he seems to have kept as near as he could to the version which he was trying to supersede, and not to have made any attempt to translate it into such Latin as he wrote himself in his letters and commentaries. Perhaps he found it was impossible to bring about any nearer approximation of the languages, or perhaps he feared the storm of obloquy that any such attempt would have aroused; in any case his version is a revision of the O.L. with the help of direct reference to the Hebrew, and not a new translation, such as might have been expected from a man of Jerome's literary powers. It is not in any sense a Latin Classic as the English Bible is an English Classic, and Cardinal Bembo was not altogether without excuse when he warned a brother Cardinal not to read the Vulgate-as Jerome's Latin version is called-lest he should spoil his Latin style.

The popular prejudice against Jerome's version was such that it was found impossible ever to induce the people to accept his version of the Psalms- the part of the O.T. most familiar to them from its use in public worship. To this day in the official edition of the Vulgate the version of the Psalms is not the one that Jerome made from the Hebrew, but a revision of the Old Latin version that he made in the early part of his life with the help of the Greek of the LXX only.

Those who wish to get some idea of what the O.L. version of the O.T. must have been will get a good idea by reading the Psalter in the Vulgate.

Jerome did not think it necessary to make a new translation of the New Testament. He revised the Gospels carefully and the rest of the N.T. in a cursory manner.

He did not set much store by the books of the Apocrypha and therefore only retranslated Tobit and Judith, and did not even revise the others. The result of his labours is thus a conposite work which after a time won universal acceptance and was declared by the Council of Trent to be 'authentic.' This version, as has been said, is called the Vulgate, or commonly received version. An authoritative text was edited by order of Popes Sixtus V and Clement VII and can be procured in many editions ${ }^{1}$. Of late years

1 An edition in good type and convenient form is that of Hetzenauer, published by Pustet. 
a new edition of the N.T. has been undertaken by the late Dr Wordsworth, Bishop of Salisbury, and Dr H. J. White, now Dean of Christ Church, Oxford.

This is being published in its full form by the Oxford Press, and a small edition is published by the Oxford Press and by the Bible Society.

It was this Vulgate version that had supreme influence in the middle ages when Greek and Hebrew were unknown to all but a very few scholars. The revival of Greek and Hebrew studies at the Renaissance was looked upon with grave suspicion by the scholars of the old learning as leading to heresy.

The old version had such a hold that even Erasmus, when he published a new Latin version in parallel columns with his edition of the Greek text, contented himself with copying the Vulgate version with the correction of a few of the most glaring solecisms. Beza put out a new version in Latin in the seventeenth century which is still published by the Bible Society. It is interesting to an advanced student to compare this version with the Vulgate ${ }^{1}$.

The points in which Ecc. I. differs from Cl. L. are principally the following:

The use of a great number of abstract and compound nouns and of nouns denoting an agent and ending in or.

The use of diminutives. The use of words transliterated from Greek.

The extended use of prepositions where in Cl. L. a simple case of the noun would have sufficed.

The disappearance of long and elaborate sentences with many dependent clauses. Clauses are often connected simply by et, or no conjunction is used at all.

The disappearance to a great extent of the Oratio Obliqua and the Accusative with Infinitive construction.

The substitution therefor of a new construction imitated from the Greek and introduced by quod, quia, or quoniam.

The gradual extension of this construction even in clauses where ut would be used in Cl. L. especially in noun clauses.

- For further information see articles on Latin Versions and Vulgate in Hastings' Dictionary of the Bible and Sir Frederick Kenyon's nur Bille and the Ancient Mamuscripts. 


\section{of Ecclesiastical Latin}

The Infinitive used to express purpose or result, as in Greek, and also to express dependent commands.

The Subjunctive is used where it would not be used in Cl. L. and vice versa.

The use of periphrastic forms of verbs, especially forms made up with esse or habeve.

In a word we see the process at work which turned the Latin of the Empire into the modern Romance languages. 


\section{SYNTAX}

\section{SENTENCES.}

1. Syntax deals with the methods by which words are combined to form sentences.

A sentence is a group of words expressing a statement, a question, or a desire. (Under the term desive commands, entreaties and wishes are to be included.)

2. Every sentence must consist of at least two parts, either expressed or understood:

(I) The Subject-the word or group of words denoting the person or thing of which the predicate is said.

(2) The Predicate-the word or group of words denoting all that is said about the subject; or the word or group of words which expresses the assertion that is made, the question that is asked, or the desire that is expressed about the subject. The predicate is not necessarily identical with the verb. It includes the complements and extensions of the verb and also the object.

If a verb is transitive it must have an object.

The Object is the word or group of words denoting the person or thing towards which the action of the verb is directed.

The verb agrees with its subject in number and person.

3. Verbs which require a complement to complete their meaning are called Copulative verbs. The most important copulative verb is the verb to be.

Verbs which signify to become, to appear, to be chosen, to be named, and the like are also copulative.

If the complement of a copulative verb is a noun, it agrees with the subject of the verb in number and case; if it is an adjective, it agrees with the subject of the verb in number, gender and case.

This rule is sometimes put in the following form:

The verb 'to be' takes the same case after it as before it.

Examples:

Caesar imperator est. Caesar is general.

Metelli facti sunt consules. The Metelli have been made consuls. Rex magnus est. The king is great. 


\section{Sentences}

Regina magna est. The queen is great.

Reges magni sunt. The kings are great.

Regnum magnum fit. The kingdom becomes great.

Felices appellamur. We are called happy.

4. A Simple sentence is a sentence which contains a single subject and a single predicate.

Multiple and Complex sentences are sentences which contain more than one subject and predicate.

In dealing with sentences it will be found convenient to keep carefully to the following terminology:

The name scntence should be applied only to a complete statement, command, or question occurring between two full stops.

Groups of words forming part of a multiple or complex sentence, and having a subject and predicate of their own should be called clatsses.

Groups of words forming an equivalent to some part of speech, and not having a subject and predicate of their own, should be called phrases.

5. A Multiple sentence is a sentence which consists of two or more clauses none of which depends on any of the others, but which all make equally important and independent statements. These clauses are said to be combined by co-ordination.

In the Heb. language such co-ordinated clanses are very common, and this peculiarity is faithfully reflected in the Vg. O.T., and, to a certain extent, in the N.T. In Latin, uninfluenced by Heb., clauses are more generally combined into complex sentences.

Example:

Et egressus est rursus ad mare: omnisque turba veniebat ad eum, et docebat eos. And he went out again to the sea, and all the crowd came to him, and he tanght them. Mk. ii, I3.

6. A Complex sentence is a sentence which consists of a principal or main clause and one or more subordinate clauses depending on it, or on one another as noun, adjective, or adverb equivalents. These clauses are said to be combined by subordination.

Example:

Si quis voluerit voluntatem ejus facere, cognoscet de doctrina, utrum ex Deo sit, an ego a meipso loquar. If any man willeth to do his wilt, he shall know of the teaching, whether it is of God, or whether I speak of myself.

Jn. vii, I 7 . 
7. Subordinate clanses are divided into three classes:
(I) Noun or Substantival clauses that take the place of a nonn.
(2) Adjectival clauses that take the place of an adjective.
(3) Adverbial clauses that take the place of an adverb.

\section{NOUNS.}

8. Cases and their meanings. Inflection is a change made in the form of a word to denote a modification of its meaning, or to show the relationship of the word to some other word in the sentence.

Examples: bird becomes birds in the Pl. and man becomes men.

The pronoun he is used when it is the subject of a sentence:

but it is changed into him when it is the object. There are

however few inflections left in English.

Latin nouns, pronouns and adjectives have inflections to show number and case; adjectives and some pronouns have inflections to show gender as well.

To give a list of these inflections is called giving a declension, or declining a word, because the cases other than the Nominative were considered by the old grammarians to fall away (declinave) from the form of the Nominative. For the same reason cases other than the Nominative are sometimes called Oblique cases.

Hence also the origin of the name Case from the Latin casus = falling.

The cases actually in use are seven in number. verb.

(I) The Nominative, used to express the subject of a finite

(2) The Vocative, used in addressing a person or thing.

(3) The Accusative, nsed to denote motion towards and to express the object of a transitive verb.

(4) The Genitive, used to limit the meaning of another noun like an adjective and to denote various relations most of which are expressed in Eng. by the nse of the preposition of or by the possessive case.

(5) The Dative, used to express that to or for which anything is done. This includes the dative of the indirect object after transitive verbs.

(6) The Ablative, used to express separation or motion from and in many other senses. 


\section{Nominative, Vocative, Accusative Cases}

(7) The Locative, which is not given in the tables of declensions in grammars, used to denote the place at which anything happens in certain expressions.

9. The Nominative Case is the case of the Subject of a sentence or clause iu all sentences or clauses in which the verb is not in the Infinitive mood.

Tunc discipuli ejus, relinquentes eum, omnes fugerunt.

Then all his disciples forsook him and fled. Mk. xiv, $5^{\circ}$.

10. The Vocative Case is used in addressing a person or a personified thing.

Bone Pastor, Panis vere, Good Shepherd, true Brcad,

Jesu, nostri miserere. Jesus, have mercy on us.

11. The Accusative Case denotes motion towards or extension.

It is therefore the case of the Direct Object, because the object is the name of that towards which the action of the verb goes forth.

So the Acc. is used with or withont a preposition to denote motion towards.

The Acc. denotes the time during which anything happens and also extent of space.

12. The Acc.is used to express the direct object of a transitiveverb.

Qui videt me, videt enm qui misit me. Ho that seeth me, seeth him that sent me. Jn. xii, 45 .

The same verbs are not necessarily transitive in Latin as in Eng., hence many verbs which are followed by an Acc. in Eng. are followed by a Gen., Dat., or Abl. in Latin.

13. Motion towards is generally expressed by a preposition such as $a d$ or $i n$ followed by a noun iu the Acc. case.

The preposition is omitted in Cl.L. before the names of towns and small islands and before certain words such as domum, rus, foras.

In the $\mathrm{Vg}$. a preposition is generally used before domum, and it is also found before the names of towns.

Non relinquam vos orphanos: veniam ad vos. I will not leave you orphans: I will come to you. Jn. xiv, I8.

Sed cum Romam venisset, sollicite me quaesivit. But when he came to Rome, he sought me out diligently. II Tim. i, I7.

Venit ergo iterum in Cana Galilaeae.... He came therefore again to Cana of Galilee....

Jn. iv, 46 . 
14. The Acc. may denote extent of time or space, but in Ecc. L. the Abl. is often used for extent of time. See section 55.

Et mansit ibi duos dies. And he remained there two day's. Jn. iv, 40 .

15. Cognate Accusative. Any verb whose meaning permits it may take after it an Acc. of cognate or kindred meaning.

Bonum certamen certavi. I have fought a good fight.

II Tim. iv, 7 .

Nolite judicare secundum faciem, sed justum judicium judicate. Do not judge after the appearance, but judge a righteous judgment.

Jn. vii, 24 .

See also Lk. ii, 8; I Tim. vi, I2; I Pet. iii, I4.

16. Certain verbs meaning to teach, to ask, to conceal are followed by two Accusatives, one of the person and another of the thing.

If a verb of this kind is used in the Passive voice the object noun denoting the thing is retained in the Acc. case.

Ille vos docebit omnia. He shall teach you all things.

Jn. xiv, 26 .

Aut quis est ex vobis homo, quem, si petierit filius suus panem, numquid lapidem porriget ei? Or what man is there of you whom, if his son ask him for a loaf, will he give him a stone?

Mt. vii, 9 .

Hic erat edoctus viam Domini. He was instructed in the way of the Lord.

Acts xviii, 25.

17. Two Object Accusatives are rarely used, in imitation of Gk., after verbs meaning to put on.

This is not $\mathrm{Cl}$. The $\mathrm{Cl}$. construction is to use the Acc. of the person and the Abl. of the thing put on.

Calcia te caligas tuas. Put on thy sandals.

Acts xii, 8.

Induite vos armaturam Dei. Put on yourselves the armour of God.

Induti loricam fidei. Clad with the breastplate of faith.

Eph. vi, I I.

So in onc instance with a verb meaning to put off:

I Thess. v, 8.

Expoliantes vos veterem hominem. Putting off from yourselves the old man.

Col. iii, 9. 
18. The Acc. is sometimes used after Passive verbs to denote an action done to oneself. This seems to be an imitation of the Greek Middle voice. This construction is rare in prose, but common in Latin poetry, where it is used with great freedom.

State ergo succincti lumbos vestros in veritate: et induti loricam justitiae, et calciati pedes in praeparatione evangelii pacis. Stand therefore with your loins givt about with truth, and having put on the breastplate of righteousness, and with y'our feet shod with the preparation of the gospel of peace.

Eph. vi, It.

Abluti corpus aqua munda. With our body washed with pure water. Heb. $x, 22$.

19. The Genitive Case is an adjectival or descriptive case. A noun in the Gen. case is generally connected with another noun which it qualifies very much in the same way as an adjective.

The Gen. case can generally be translated into Eng. by the use of the prepasition of or by the Possessive case.

The name Genitive case means the case of kind or origin; but the case is most frequently used to denote possession.

20. Possessive Genitive denoting possession.

Justorum autem animae in manu Dei sunt. But the souls of the righteous are in the hand of God. Wisdom iii, I.

21. The Gen. may express authorship, source, or material, or almost any relationship that can exist between two persons or things.

Inter natos mulierum. Among those born of women.

Mt. xi, I I.

Periculis fluminum, periculis latronum. In perils of vivers, in perils of robbers... (i.e. arising from rivers or robbers).

II Cor. xi, 26.

Ergo evacuatum est scandalum crucis. Thevefore the reproach of the cross has ceased.

Prae gaudio illius. For joy thereof.

Gal. v, I I .

Mt. xiii, 44 .

So the Gen. is used to denote personal relationship such as that of son and father, mother and son, or even husband and wife

Dicebat autem Judam Simonis Iscariotem. But he spake of Judas the son of Simon the Iscariot.

Jn. vi, $7 \mathbf{I}$.

Stabant autem juxta crucem Jesu... Maria Cleophae et Maria Magdalene. But Mary the wife of Cleophas and Mary Magdalene were standing by the cross of Jesus. Jn. xix, 25. 
22. The Partitive Genitive expresses the whole after words denoting a part.

Magister bone, quid boni faciam, ut habeam vitam aeternam? Good Master, what good thing shall I do that I may have eternal life?

Mt. xix, I6.

See also Mt. xxv, I9; Acts v, I5; Rom. xv, 26; Acts xxiv, 21 .

23. The Subjective Genitive. The Gen. is said to be used subjectively when the noun which is in the Gen. case is the name of the subject of the action denoted by the noun with which it is connected.

Quis nos separabit a caritate Christi? Who shall separate us from the love of Christ? (i.e. from the love that Chvist feels for us). Rom. viii, 35 .

Propter quod tradidit illos Deus in desideria cordis eorum. Wherefore God gave them up to the desives of their own heart.

See also II Cor. v, I 4 ; I Tim. iv, I.

Rom. i, 24.

The Subjective Gen. is also found in the $\mathrm{Vg}$. after adjectives and participles in imitation of the Gk.

Et erunt omnes docibiles Dei. And they shall all be taught of God. Jn. vi, 45 .

Quae et loquimur non in doctis humanae sapientiaeverbis.... Which also we spcak, not in words taught by hman wisdom....

I Cor. ii, I3.

24. The Objective Genitive. The Gen. is said to be used objectively when the noun which is in the Gen. case is the name of the object of the action denoted by the nown with which it is connected.

The objective Gen. is used much more freely in the $\mathrm{Vg}$. than in Cl. L., in initation of the Gk. It is often used with nouns which express the action of an intransitive verb.

Dedit illis potestatem spirituum imniundorum. He gave them power (to cast out) muclean spirits.

Mt. $\mathrm{x}, \mathrm{I}$.

Sicut dedisti ei potestaten omnis carnis. As thou hast given him power over all flesh.

Jn. xvii, 2.

Et erat pernoctans in oratione Dei. And he was spending all the night in proyer to God.

Lk. vi, I 2.

Si nos hodie judicamur in benefacto hominis infirmi... If we are judged to-day for a good deed done to an impotent man....

Acts iv, 9. 


\section{Genitive Case}

Quidam autem conscientia usque nunc idoli, quasi idolothytum manducant.... For some men with the consciousness even now of the idol eat it as a thing offered to an idol....

I Cor. viii, 7 .

Spiritus autem blasphemia non remittetur. But blasfhemy against the Spirit shall not be forgiven.

Mt. xii, 31 .

See also Mk. xi, 22; Jn. ii, I 7 ; Rom. x, 2, xv, 8; II Cor. x, 5 ; Col. ii, I2; I Tin. iii, 5.

25. The Possessive Pronoun may be used in the sense of an objective Gen.

Hoc facite in mcam commemorationem. Do this in remembrance of me.

Lk. xxii, 19.

Quaecumque enim scripta sunt, ad nostram doctrinam scripta sunt. For whatsoever things were written were written for our learning-(i.e. to teach us).

Rom. xv, 4 .

Neque veni Hierosolymam ad antecessores meos apostolos. Nor did I go to Jerusalem to the apostles who were before me.

Gal. i, I 7 .

Ita et isti non crediderunt in vestram misericordiam. So they atso did not believe that mercy might be shown to you.

Rom. xi, 3I.

Quotidie morior per vestram gloriam, fratres, quam habeo in Christo Jesu Domino nostro. I die daily, brethren, I protest by the glorying in you which I have in Christ Jesus our Lord.

I Cor. Xv, $3 \mathrm{I}$.

The question whether a Gen. is subjective or objective can only be decided by the context. Sometimes the decision is not easy.

26. The Descriptive Genitive is used to give a description or explanation of the noun with which it is connected.

In Cl. L. a descriptive Gen. is always qualified by an adjective; but this is not always the case in Ecc. L.

In the Vg. the use of this Gen. is widely extended in imitation of the Construct state in Heb. There are few adjectives in Heb., and a noun in the Construct state is connected with another noun where an adjective would be used in Latin or Gk.

Et facti estis judices cogitationum iniquarum. And ye become judges with evil thoughts (i.e. unfair judges). Jas. ii, 4. Quia propter te mortificamur: tota die aestimati sumus ut 
oves occisionis. Because we are put to death for thy sake: all the day we are counted as sheep for the slaughter.

Rom. viii, 36, quoted from Ps. xliii, 22.

In odorem suavitatis. For a sweet smelling savour.

Eph. v, 2.

Annorum enim erat amplius quadraginta homo, in quo factum erat signum istud sanitatis. For the man was more than forty years old on whom this sign of healing was done.

Acts iv, 22.

See also Mt. viii, 26; Mk. i, 4; Lk. ii, I4; Jn. v, 29, vii, 35; Rom. xv, 5; Phil. iii, 2 I.

27. The descriptive Gen. may also be used predicatively.

Nescitis cujus spiritus estis. Ye know not of what spirit ye are.

Lk. ix, 55 .

Nam ut impudentis est clamoribus strepere, ita congruit verecundo modestis precibus orare. For as it is the mark of a shameless person to make a disturbance with his cries, so it befits a modest person to pray with vestraint.

Cyprian, De Oratione Dominica.

28. The Genitive of price or value. The Gen. of some neuter adjectives such as magni, parvi, tanti, quanti, is used to denote the price at which a thing is valued, bought or sold.

Dixit autem ei Petrus: Dic mihi, mulier, si tanti agrum vendidistis? But Peter said to her: "Tell me, woman, if you sold the ficld for so much?"

Acts v, 8; Lk. xii, 24.

29. The Gen. is used after certain verbs which are not transitive in Latin as they are in Eng.

Most verbs meaning to pity, to remember, to forget, are followed by a Gen. case in Cl. L.

In the Vg. the usage varies. A Dat. is found after misercor and sometimes super with an Acc.

Ps. cii, x 3 ; Prov. xxi, ro; Mt. ix, 36; Mk. viii, 2. Recordor is very rarely followed by an Acc.

Memini is also rarely followed by an Acc.

Hos. vii, 2; Ez. xxiii, I9. Is. xlvi, 8; I Macc. vii, 38 .

Obliviscor is followed by an Acc.

Ps. ix. I8, xlix, 22; Heb. xiii, 2. The following are examples of the normal use. 


\section{Uses of Genitive Case in Ecc. Latin}

Misertus autem dominus servi illius, dimisit eum. But the lord taking pity on that slave, forgave him.

Mt. xviii, 27.

Omnia ostendi vobis, quoniam sic laborantes oportet suscipere infirmos, ac meminisse verbi Domini Jesu, quoniam ipse dixit: Beatius est magis dare quam accipere. I have shown you all things, that so labouring ye ought to support the weak, and to remember the word of the Lord Jesus, how he said: "It is more blessed to give than to receive."

Acts $\mathrm{xx}, 35$.

Non enim injustus Deus, ut obliviscatur operis vestri.... For God is not unjust that he should forget your work....

Heb. vi, Io.

30. The following uses of the Gen. which are not found in Cl. L., but which are found in the Vg., in imitation of Gk., should be noted.

Verbs meaning to rule and to fill are followed by a Gen. and also the adj. plentts, full.

Reges gentium dominantur eorum. The kings of the nations rule over them.

Lk. xxii, 25.

Et impletae sunt nuptiae discumbentium. And the wedding was filled with guests.

Mt. xxii, Io.

See also Acts xix, I6; Rom. xiv, 9.

\section{The Genitive Absolute is found}

Qui ostendunt opus legis scriptum in cordibus suis, testimonium reddente illis conscientia ipsorum, et inter se invicem cogitationum accusantium, aut etiam defendentium. Who show the work of the law written in their hearts, their ozen conscience bearing testimony to them, and their thoughts accusing them, or even defending them to themselves.

Rom. ii, 15.

This is the reading of Wordsworth and White. The SC text reads cogitationibus accusantibus, etc.

See also Acts i, 8; II Cor. x, I 5 .

At first sight it might seem that these passages might be explained differently, more in accordance with Latin usage; but the original Gk. shows that the construction is meant for the Gen. Absolute.

32. The Gen. is used after the comparative of an adjective.

Qui credit in me, opera quae ego facio et ipse faciet: et majora horum faciet.... He that believes in me, the works that I do he shall do also: and greater than these shall he do....

Jn. xiv, I 2 .

See also Mk. xii, 3I; Acts xvii, I I; Heb. iii, 3, vi, I6; III Jn. 4.

33. The Gen. may be used to express space within which.

Et videtis, et auditis, quia non solum Ephesi, sed paene totius Asiae, Paulus hic suadens avertit multam turbam.... And y'e see and hear that not only at Ephesus, but throughout almost all Asia, this Paul persuades and turns away much people.

Acts xix, 26. 
34. The Dative Case denotes that to or for which anything is done. It is generally translated into Eng. by the use of the prepositions to or for.

N.B. The Dat. does not denote motion to.

35. The Dat. of the Indirect Object is used after many verbs which are also followed by a direct object in the Acc. case.

Pecuniam copiosam dederunt militibus.... They gave large money to the soldiers...

Mt. Xxviii, I 2.

36. When verbs which are followed by an indirect object in the Dat. as well as by a direct object in the Acc. are used in the Passive voice, the direct object becomes the subject of the sentence and the Dat. remains.

Auferetur a vobis regnum Dei, et dabitur genti facienti fructum ejus. The kingdom of God shall be taken from you and given to a nation bringing forth the fruit thereof. MIt. xxi, 43 .

37. The Dat. is used after many verbs which are not transitive in Latin as they are in Eng.

The most important of these verbs are:

imperare, to command.

ignoscere, to pardon.

remittere, to pardon.

parcere, to spare.

credere, to believe.

obedire, to obey.

suadere, to persuade. servire, to serve.

placere, to please.

displicere, to displease.

nocere, to injuve.

res istere, to resist.

confiteri, to confess, give honour to.

evangelizare, to preach the gospel.

Some verbs that are followed by a Dat. in Cl. L. are followed by an Acc. in Ecc. L.

Credere is often followed by in with the Acc., benedicere and maledicere are followed either by the Dat. or the Acc.

Many verbs compounded with a preposition are followed by a Dat., especially compounds of esse.

Etenim Christus non sibi placuit. For even Christ pleased not himself.

Rom. xv, 3 .

Hujuscemodi enim Christo Domino nostro non serviunt, sed suo ventri. For men of this kind do not serve Christ our Lord, but their oren belly.

Rom. xvi, I 8.

Et obtulerunt ei omnes male habentes. And they brought to him all that were siet.

Mt. iv, 24. 
Quid milni prodest, si mortui non resurgunt? What doth it profit we if the dead rise not?

I Cor. xv, 32.

38. If a verb which is followed by the Dat. as its sole object is used in the Passive voice, it is always used impersonally.

Si enim aliquis diceret aliquid de aliqua terra remota, et ipse non fuisset ibi, non crederetur ei sicut si ibi fuisset. For if anyone should say anything about some distant land, and he himself had not been there, he would not be believed, as he would be, if he had been there.

Thomas Aquinas.

39. The Dat. may denote the person in whose interest, or against whose interest anything takes place.

Et ecce aperti sunt ei caeli.... And behold the heavens were opened for him....

Mt. iii, I6.

Quomodo aperti sunt tibi oculi? How were thine eyes opened for thee?

Jn. ix, 10 .

Tibi soli peccavi, et malum coram te feci. Against thee only have I sinned, and done evil in thy sight.

See also Mt. xxi, 2, 5, xxvii, 2 I .

40. The Dat. is used with esse to denote possession.

Quod tibi nomen est? What is thy name? Lk. viii, 30. Argentum et aurum non est mihi. Silver and gold have I none.

Acts iii, 6 .

41. The Dat. of certain nouns (in Ecc. L. these are generally nouns denoting emotions) is used, especially with esse to denote result or purpose. This Dat. is generally accompanied by another noun or pronoun in the Dat. denoting the person interested.

Et eritis odio omnibus gentibus propter nomen meum. And ye shall be hated of all nations for my name's sake. Mt. xxiv, 9.

Et nihil eorum Gallioni curae erat. And Gallio cared for none of these things.

Acts xviii, 17 .

See also Col. iv, I I I Thess. ii, 7.

42. The Dat. is regularly used to express the Agent after a gerundive participle and rarely after a perfect participle.

Audistis quia dictum est antiquis... Ye have heard that it was said by them of old time...

Mt. $v, 2 \mathrm{I}$.

Novissime autem omnium tanquam abortivo, visus est et 
mihi. And last of all he was seen by me also, as by one born out of due time.

I Cor. xv, 8.

Et ecce nihil dignum morte actum est ei. And behold nothing zorthy of death has been done by him.

Lk. xxiii, I 5 .

43. A quite exceptional instance of the Dat. being used to express motion towards is found in Rev. i, I r.

Et mitte septem ecclesiis. And send it to the seven churches.

This is, as usual, an exact translation of the Gk.

44. The Ablative Case may be described as an adverbial case, because a noun in the Abl. case generally qualifies a verb, adjective or adverb in the same way as an adverb.

The name Ablative case means the taking away case. It is a very unsuitable name, as it covers only a small number of the uses of the case.

The meanings of the Abl. case, as we find it in Latin, are derived from the meanings of three different cases which existed in the primitive form of the language:

I. A true Ablative case, denoting separation, or the place from which anything is taken.

2. An Instrumental, or Sociative case, denoting the instrument by means of which anything is done, or the accompanying circumstances of the action.

3. A Locative case, denoting the place where, or the time when anything happens.

The particular kind of meaning denoted by a noun standing in the Abl. case depends partly on the meaning of the noun itself and partly on the meaning of the word with which it is connected.

Thus in the sentence Roma abiit, He went from Rome, Roma is obviously used in the proper Abl. signification of separation from.

In the sentence Baculo puevum percussit, He struck the boy with a stick, Baculo is Instrumental.

In the sentence Proximo amno rediit, He returned next year, anno is Locative.

The student must always consider the context in which a word in the Abl. case is found before attempting to translate it.

The meanings of the case are so various, that it is not well to attach too definite a meaning to it in the mind. 


\section{Ablative Case}

In many instances, especially in late Latin, a preposition is placed before a noun in the Abl. case to make its meaning more precise.

45. The Ablative of Separation, generally translated 'from.' In $\mathrm{Cl}$. L. the Abl. is used without a preposition to denote motion from a place when the place spoken of is a town or small island.

The Abl. of certain words such as domo is used in the same way.

In Ecc. L. a preposition may be used with nouns of this kind; with all other nouns a preposition is used to denote motion from.

Et alia die cum exirent a Bethania, esuriit. And on another day when they came out from Bethany he was hungry.

See also Acts xviii, I, xxv, I.

Mk. xi, I2.

46. The Abl. is used with verbs and adjectives denoting separation, deprivation, release or want and also with words denoting descent or origin.

In Ecc. L. a preposition is often used after such words.

Qui veritate privati sunt. Who are deprived of truth.

I Tim. vi, 5 .

47. The Instrumental Ablative and the Ablative of Attendant Circumstances, generally translated 'with.'

The Ablative of the Instrument. The word that denotes the means by which anything is done is put in the Abl. without a preposition.

Occidit autem Jacobum fratrem Johannis gladio. But he killed James the brother of John with a sword. Acts xii, 2.

In the Vg. the prepositions $a$ or in are sometimes found before a word denoting the Instrument in imitation of Heb., or of Gk. influenced by Heb.

Et commota sunt superliminaria cardinum a voce clamantis. And the posts of the door were moved by the voice of him that cried.

Isa. vi, 4 .

Ego baptizo in aqua.... I baptize with water.... Jn. i, 26.

Domine, si percutimus in gladio? Lord, are we to strike with the sword?

Lk. xxii, 50 .

See also James iii, 4.

48. The Ablative of Manner. The word which denotes the manner in which anything takes place is put in the Abl., without a preposi- 
tion if it is qualified by an adjective: if it is not qualified by an adjective, the preposition $\mathrm{cum}$ is used before it.

At illi instabant vocibus magnis postulantes ut crucifigeretur. But they were urgent with loud voices demanding that he should be crucified.

Lk. xxiii, 23.

Qui autem supra petrosa seminatus est, hic est qui verbum audit, et continuo cum gaudio accipit illud. But he that was sown on the stony places, this is he who hears the word, and immediatcly with joy receives it.

Mt. xiii, 20.

The preposition is used in Ecc. L. even when the noun denoting manner is qualified by an adjective.

Qui susceperunt verbum cum omni aviditate... For they received the word with all eagemess....

Acts xvii, II.

49. Verbs and adjectives denoting filling or equipping may be followed by a word in the Abl. denoting that with which the filling or equipping is done.

In the Vg. such verbs and adjectives may be followed by a word in the Gen. in initation of Gk.

O plene omni dolo, et omni fallacia.... O full of all guile and all deceit.... Acts xiii, Io.

Et impletae sunt nuptiae discumbentium. And the wedding was fumished with guests.

Mt. xxii, Io.

Plenum gratiae et veritatis. Full of grace and truth. Jn. i, I 4 .

50. The Ablative of Price. The word which denotes the price at which anything is bought, sold or hired, is put in the Abl. case.

Quare hoc unguentum non veniit trecentis denariis? Why was not this unguent sold for three hundred pence? Jn. xii, 5 .

See also Mk. vi, 37; Acts xxii, 28.

51. The Ablative Absolute. A noun or pronoun in the Abl. case with a predicative participle, or adjective, or even another noun agreeing with it, is used to denote an incident that accompanies or explains the action of the verb on which it depends like an adverbial clause. This construction is very common in Latin, and is called the Ablative Absolute, because it is independent of, or loosed from (absolutus), the main structure of the sentence.

The Abl. in this construction is an Abl. of accompanying circumstances. A phrase of this kind is generally best translated into Eng. by an Adverbial clause. The kind of Adverbial clause most 
suitable for the translation of any particular instance of this construction is determined by the context; generally speaking it will be either a clause of Time, a clause of Cause, or a clause of Concession. See sections I 53, I 56, I 66 .

The noun in the Ablative Absolute construction should not denote the same person or thing as the subject or object of the clause on which it depends.

This rule is however frequently violated in Ecc. L.

In Eng. there is a similar construction which is called the Nominative Absolute.

It is seen in the following sentence:

This done, he went home.

In Latin this sentence would be:

Hoc facto domm abiit.

A closer parallel is seen in the colloquial use of a phrase beginning with with:

"With things being so dear I shall never be able to manage it."

Examples of the Ablative Absolute:

I. Equivalent to a clause of Time.

Et ejecto daemone, locutus est mutus. And when the devil was driven out, the dumb man spake. Mt. ix, 33.

Et cum haec dixisset, videntibus illis, elevatus est. And when he had said this, as they were looking on, he was taken up. Acts i, 9 .

2. Equivalent to a clause of Cause.

In quo admirantur non concurrentibus vobis in eandem Iuxuriae confusionem. In which they wonder, because you do not vun with them into the same slough of debauchery. I Pet.iv, 4.

The following are examples of the ungrammatical use of the Abl. Absolute, where the noun in the Abl. refers to the same person as the object of the clause with which the Abl. Absolute is connected.

Et ascendente eo in naviculum, secuti sunt eum discipuli ejus. And when he went up into a ship, his disciples followed him.

Mt. viii, 23.

Paulo autem volente intrare in populum, non permiserunt discipuli. But when Paul wished to go in to the people, the disciples suffered him not.

Acts xix, 30 .

See also Mt. viii, 3t, ix, 27; Acts vii, 21, x, 19, xx, 1. 


\section{Ablative of Place}

Rarely a participle stands in the Abl. by itself in this sense:

Videntes autem Petri constantiam et Johannis, comperto quod homines essent sine litteris et idiotae.... But seeing the boldness of Peter and John, and finding ont that they weve unlettered and ordinary men....

Acts iv, I3.

The following is a very harsh example of an Abl. Absolute used to translate a Gk. active participle agreeing with the subject of the main clanse.

Quo statim cognito Jesus spiritu suo quia sic cogitarent intra se.

This is untranslatable as it stands. It is meant to translate

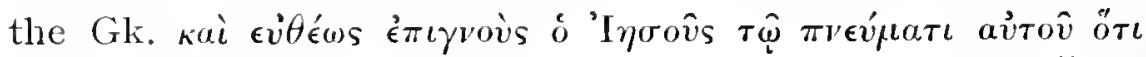

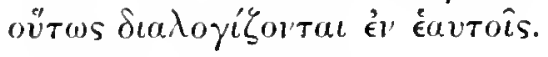

Mk. ii, 8 .

52. Locative Ablative, or Ablative of Place or Time, generally translated 'in' or 'at.'

Ablative of Place. The Abl. case is used to denote the place in which, or the time at which anything happens.

In Ece. L. it is often preceded by a preposition where one would not be user in $\mathrm{Cl}$. L.

The way in which the place at which anything happens is expressed in $\mathrm{Cl}$. L. is somewhat peculiar.

Generally speaking the preposition in is used followed by a noun in the Abl. case; but if the place spoken of is a town or small island the name of the town or small island is put in the so-called Locative case. This ends in ae in singular nouns of the rst declension and in $i$ in singular nouns of the 2 d d declension. In the plural of these declensions, and in the 3 rd declension, the ending of the Loc. case is the same as the ending of the Abl.

Examples:

Romae, At Rome. Corinthi, At Corinth. Athenis, At Athens.

The Loc. case is also found in the words domi at home: ruve in the country: foris out of doors.

In Ecc. L. the Loc. is sometimes found in the names of towns: sometimes in with the Abl. is used.

Erat autem quidam discipulus Damasci... But there was a certain disciple at Damascus....

Acts ix, Io.

Paulus autem, cum Athenis eos expectaret.... But Paul, when he was wating for them at Athens.... Acts xvii, I6.

Et erat vir in Lystris infirmus pedibus.... And there was a man in Lystra lame in his feet...

Acts xiv, 7 . 


\section{Ablative of Time}

53. A kind of Loc. Abl. is used to express the thing in respect of which a statement is made, especially in words denoting a part of the body or mind. This is sometimes called the Abl. of Respect.

Vir infirmus pedibus.... A man lame in his feet....

Beati pauperes spiritu. Blessed are the poor in spirit.

Acts xiv, 7 .

Mt. $v, 3$.

Fratres, nolite pueri effici sensibus: sed malitia parvuli estote. Brethren, do not become children in sense: but in malice be ye babes.

I Cor. xiv, 20.

Sed ad sua desideria coacervabunt sibi magistros, prurientes auribus. But at their desire they will heap up to themselves teachers: itching in the ears.

II Tim. iv, 3 .

Mattheum nomine. Matthew by name.

See also Acts vii, 5 I.

54. Ablative of Time. The time at which anything happens is denoted by the Abl. when the noun denotes a period of time.

In Ecc. L. a preposition may be used.

Quinta autem vigilia noctis venit ad eos, ambulans supra mare. But in the fifth watch of the night he came to them, walking on the sea.

Mt. xiv, 25.

In diebus autem illis venit Johannes Baptista, praedicans in deserto Judaeae. But in those days John the Baptist came preaching in the desert of Judea.

IIt. iii, I.

55. The Abl. of nouns denoting a period of time may be used to denote the time within which anything happens.

This use is widely extended in the $\mathrm{Vg}$. to denote the time during which anything takes place, which is denoted in $\mathrm{Cl}$. L. by the Acc. case.

Quadraginta et sex annis aedificatum est templum hoc, et tu tribus diebus excitabis illud? Forty and six years was this temple in building, and wilt thou raise it up in three days?

Jn. ii, 20 .

Tanto tempore vobiscum sum? Have I been so long with you?

Quid hic statis tota die otiosi? Why stand ye here all the day idle?

Mt. $\mathrm{xx}, 6$.

Et erat tribus diebus non videns. And he was three day's without sight.

Acts ix, 9. 
56. The Adjectival Ablative or Ablative of Description describes a person or thing. The noun in the Abl. generally denotes a feature of the body or mind and is always qualified by an adjective.

Patres, nolite ad indignationem provocare filios vestros, ut non pusillo animo fiant. Fathers, do not provoke your children to wrath, that they may not become of feeble mind. Col. iii, 2 I.

Beati mundo corde. Blessed are the pure in heart. Mt. v, 8.

57. Ablatives used with verbs. The Abl. is used after certain verbs which are not transitive in Latin as they are in Eng.

The commonest of these verbs are:

$$
\begin{array}{ll}
\text { utor, I use. } & \text { potior, I get possession of. } \\
\text { fruor, I enjoy. } & \text { careo, I am without. } \\
\text { fungor, I perform. } & \text { egeo, indigeo, I need. }
\end{array}
$$

Ego autem nullo horum usus sum. But I have used none of these things.

I Cor. ix, I 5 .

Pro Christo ergo legatione fungimur. We therefore perform the office of ambassador on behalf of Christ. II Cor. v, 20.

Et civitas non eget sole neque luna, ut luceant in ea. And the city needs not the sun or moon to shine in it.

Rev. xxi, 23.

Egeo is used with a Gen. in imitation of Gk. in Rev. iii, I 7 .

58. The adjectives dignus and indigmus are generally followed by a noun in the Abl.

In the $\mathrm{Vg}$. they are sometimes followed by a noun in the Gen. in imitation of Gk.

Dignus est operarius cibo suo. The workman is worthy of his food.

Mt. $\mathrm{x}, \mathrm{IO}$.

Amplioris enim gloriae iste prae Mose dignus habitus est. For he was thought worthy of move glory than Moses.

Heb. iii, 3 .

\section{PRONOUNS.}

59. A Pronoun is a word used instead of a noun to point out or enumerate persons or things without naming them.

Many words classed as pronouns can be used as adjectives to define or point out nouns. 


\section{Pronouns-Personal}

Personal and Reflexive pronouns can only be used in place of nouns. Possessive, Demonstrative, Relative, Interrogative and Indefinite pronouns can be used either in place of nouns or adjectivally.

When a pronoun can be used adjectivally it should be called an Adjectival Pronoun.

As a rule pronouns agree in gender and number with the noun in placè of which they are used, but sometimes they agree only in sense with the noun and not with its grammatical number and gender.

Thus a plural pronoun may be used with reference to a collective noun, a neuter plural pronoun may be used with reference to two feminine nouns denoting things without life, a plural pronoun may be used with reference to a country because the thought is directed rather towards its inhabitants.

Euntes ergo docete omnes gentes, baptizantes eos.... Go therefore and teach all nations, baptizing them.... IIt. xxviii, I9.

Possessiones et substantias vendebant, et dividebant illa omnibus.... They sold their possessions and goods and divided them all....

Acts ii, 45 .

Et circumibat Jesus totan Galilaeam, docens in synagogis eorum. Jesus went about all Galilee, teaching in their synagogges.

IIt. iv, 23.

Sed habes pauca nomina in Sardis, qui non inquinaverunt vestimenta sua. But thou hast a few names in Sardis, who have not defiled their garments.

Rev. iii, 4.

See also Rom. ix, 24.

60. Personal Pronouns. As the ending of a Latin verb shows what person and number its subject is, the Nominative of personal pronouns is seldom used, except when special emphasis is desired.

Nos audivimus ex lege quia Christus manet in aeternum; et quomodo tu dicis: Oportet exaltari filium hominis? We have heard out of the law that Christ abideth for ever; and how sayest thou: "The Son of man must be lifted "tp"? Jn. xii, 34 .

Ille erat lucerna ardens et lucens. Vos autem voluistis ad horam exultare in luce ejus. He was a buming and a shining light. But you were willing for a season to rejoice in his light.

Jn. v, 35 .

There are no personal pronouns of the third person in Latin except the Reflexive se. Demonstrative and Relative pronouns are used to take the place of the missing personal pronom. 
Ille, ipse, iste and hic are all used as personal pronouns of the third person in the $\mathrm{Vg}$. quite commonly, as well as is.

See Jn. ix, 8, I2, I8, 2I, 36; Lk. ix, 9.

61. Reflexive Pronouns may be treated as a branch of personal pronouns. They are used when the subject of the verb is described as acting on himself, or in his own interest, or as saying or thinking something about himself.

In the first and second persons reflexive pronouns are identical in form with the oblique cases of the personal pronouns: in the third person both singular and plural the forms se, sui, sibi, se are used.

Nihil feceris tibi mali. Do thyself no harm. Acts xvi, 28.

Et abiens laqueo se suspendit. And going away, he hanged himself.

Mt. xxvii, 5 .

When reflexive pronouns are used in a subordinate clause they sometimes refer to the person denoted by the subject of the main clause. This is seldom the case where any ambiguity is likely to be caused.

The use of reflexive pronouns is rather loose in Ecc. $\mathrm{L}$.

Et cadens in terra audivit vocem dicentem sibi... And falling to the earth he heard a voice saying to him....

Acts ix, 4 .

Dispersit superbos mente cordis sui. He hath scattered the proud in the imagination of their hearts.

See also Acts xxviii, I6; Mt. vii, Ir.

Lk. i, $5^{\mathrm{I}}$.

Rarely a demonstrative pronoun is used in the $\mathrm{Vg}$. where a reflexive pronoun would have been more correct.

Exinde coepit Jesus ostendere discipulis suis, quia oporteret eum ire Hierosolymam... From that time Jesus began to show to his disciples that he must go to Jerusatem.

See also Mk. x, 32; Rom. iii, 26.

62. Possessive Pronouns are used adjectivally and are equivalent to the Gen. case of the personal or reflexive pronoun.

In the first and second persons the Gen. of the personal prononn is rarely found in the sense of a possessive pronoun. Phil. ii, I2.

In the third person sums is used reflexively, that is when the person or thing to which it refers is the subject of the sentence or clause in which it stands.

Propterea ergo magis quaerebant eum Judaei interficere: 


\section{Pronouns-Demonstrative}

quia non solum solvebat Sabbatum, sed et Patrem suum dicebat Deum. On this account therefore the Jews songht the more to kill him, because he was not only breaking the Sabbath,

but also because he said that God was his Father.... Jn. v, I 8 .

When the person or thing referred to by the pronoun is not the subject of the sentence or clause in which it stands, the Gen. of a demonstrative pronoun (generally ejus or eorum etc.) is used as the possessive pronoun of the third person.

Princeps autem sacerdotum Ananias praecepit adstantibus sibi percutere os ejus. But the chief of the priests Ananias commanded those that stood by him to smite his mouth (i.e. Paul's mouth).

Acts xxiii, 2.

Sometimes where no ambiguity is likely to be caused sums is used in a subordinate clause when the person or thing to which it refers is denoted by the subject of the main clause.

Idem cum Johanne ad nonam horam ad templum adibat, ubi paralyticum sanitati reformavit suae. He went with John to the temple at the ninth hour, where he restored the paralytic to his health.

Tert. de Oratione xxv.

N.B. In Latin, as in French, the gender of a possessive pronoun does not depend on the gender of the word denoting the possessor; but possessive pronouns agree with the nouns which they qualify in gender, number and case, like adjectives.

Sua mater, His mother. Suus pater, Her father.

63. Demonstrative Pronouns are used to point out some person or thing.

In Cl. L. hic, haec, hoc denotes that which is near to the speaker and is generally translated this.

Ille, illa, illud denotes that which is more remote, and is generally translated that.

Iste, ista, istud denotes that which belongs to the person spoken to; it is sometimes used contemptuously and translated that of yours.

$I s, e a, i d$ is an unemphatic word, generally used as a personal pronoun of the third person and translated he, she, it.

Ipse, ipsa, ipsum is emphatic, and may be translated himself, herself, itself.

It is often used in speaking of a famous person, and so it is often used of God and Christ in the Vg.: it is used with other pronouns 
to give emphasis and also to show that they are reflexive. See examples below.

Idem, eadem, idem means the same.

64. In Ecc. $\mathbf{L}$. the demonstrative pronouns are not strictly used in the senses given above: iste is often used where hic or ille would be used in Cl. L.

Ipsi scitis: quoniam ad ea quae mihi opus erant, et his qui mecum sunt, ministraverunt manus istae. Ye yourselves know that these hands have ministered to those things that were needful for me and for those that were with me.

Acts $\mathrm{xx}, 34$.

Omnes vos scandalum patiemini in me in ista nocte. All y'e shall be caused to stumble because of me this night. Mt. xxvi, $3 \mathrm{I}$. For an example of hic and iste used in exactly parallel senses:

Vos ascendite ad diem festum hunc: ego non ascendo ad diem festum istum. Go ye up to this feast: I go not up to this feast.

Jn. vii, 8 .

See also Rom. xi, 30, 3I.

Hic and ille are sometimes used to translate the Greek definite article. Sce Jn. ix, 3o: respondit ille homo ( $\dot{\alpha} a \nu \theta \rho \omega \pi o s)$. Ps. cxii, 2 : ex hoc nunc (ả Tò $\tau o \hat{v} \nu \hat{v} v)$.

The following are examples of the use of $i p s e$.

Emphatic use.

Omnia per ipsum facta sunt. All things were made throngh him.

Jn. i, 3 .

Johannes testimonium perhibet de ipso. John bears witness about him.

Jn. i, I 5 .

Deus ipse Dominus; ipse fecit nos, et non ipsi nos. God Himself is the Lord; He has made us, and not we ourselves.

Ps. xcix, 3.

Ego scio eum, quia ab ipso sum, et ipse misit me. I know him, because I am from him, and he sent me. Jn. vii, 29.

\section{Reflexive use.}

Tu de te ipso testimonium perhibes. Thou bearest witness of thyself. Jn. viii, I 3, 28; Rom. xii, I6.

Ipse is also used in the sense of the same:

Ex ipso ore procedit benedictio et maledictio. Out of the same mouth proceedeth blessing and cursing. Jas. iii, IO.

See also Heb. xiii, 8 . 


\section{Pronouns-Relative}

Idipsum is used in the sense of the same to translate Gk. rò airb.

Idipsum autem latrones improperaverunt ei. But the robbers cast the same reproach at him. Mt. xxvii, 44; I Cor. i, 10; Heb. iv, 1 I. In idipsum is used in the sense of together to translate Gk. ėi io aíto.

Dominus autem augebat, qui salvi fierent quotidie in idipsum. But the Lord increased daily those who should be saved into one body.

Acts ii, 47 .

Et iterum revertimini in idipsum. And come together again.

I Cor. vii, 5 .

Magnificate Dominum mecum: et exaltemus nomen ejus in idipsum. O magnify the Lord with me: and let us exalt his name together.

Ps. xxxiii, 4 .

Hierusalem quae aedificatur ut civitas, cujus participatio ejus in idipsum. Jerusalem rehich is built as a city that is at unity in itself.

See also Pss. 1xi, 10, lxxiii, 6.

Ps. cxxi, 3 .

65. The Relative Pronoun is used like a conjunction to connect two clauses in a sentence: the second of the two connected clauses may be either subordinate to, or co-ordinate with the first.

The relative pronoun always refers back to some noun or pronoun (expressed or implied) in the clause which it connects to the clause in which it stands. This noun or pronoun is called its Antecedent. In Latin, relative pronouns agree with their antecedent in gender, number and person, but not in case.

The case of a relative pronoun depends on the function which it performs in the clause in which it stands.

The relative pronoun can never be omitted in Latin as it often is in Eng.

Examples:

Accepistis illud... sicut verbum Dei, qui operatur in vobis, qui credidistis. You received it. . as the word of God who works in you who believe.

I Thess. ii, I3.

Discedite a me, qui operamini iniquitatem. Depart from me ye that work iniquity.

Mt. vii, 23.

66. A relative pronoun often stands at the beginning of a sentence and must then be 'translated into English by and followed by a personal pronoun ${ }^{1}$.

It is often used in the $\mathrm{Vg}$. to translate the Gk. $\dot{\delta} \delta \dot{\epsilon}$.

1 An unsuccessful attempt to introduce this construction into English is to be noted in several places in the A.V., especially in Acts. See Acts xiv, I4. 
Qui cum recedissent, ecce angelus Domini apparuit in somnis Joseph...qui consurgens accepit puerum. And when they had departed, behold an angel of the Lord appeared to Joseph in a dream... and he arose and took the child. Matt. ii, r3.

Quorum fidem ut videt, dixit.... And when he saw their faith, he said...

Lk. $v, 20$.

A very harsh example is found in Acts xvii, I I :

Hi autem erant nobiliores eorum qui sunt Thessalonicae, qui susceperunt verbum cum omni aviditate... But these were more noble than those who are at Thessalonica, for they received the word with all eagerness....

See also Mt. xv, 23; Jn. i, 38; Acts vii, 2.

67. Attraction of the Antecedent. The antecedent may be attracted into the case of the relative and at the same time be placed in the relative clause. When this happens a personal pronoun in the right case may take the place of the antecedent in the clause to which it properly belongs.

Quem ego decollavi Johannem, hic a mortuis resurrexit. John whom I beheaded is risen from the dead.

Mk. vi, $\mathbf{1} 6$.

Omne verbum otiosum quod locuti fuerint homines, reddent rationem de eo in die judicii. Every idle word that men shall speak, they shall give account thereof in the day of judgment. MIt. xii, 36 .

See also Mt. xxi, 42; Danl. iv, I 7 .

An example of inverse attraction, that is of the relative being attracted into the case of the antecedent, is found in Ps. ix, 23: Comprehenduntur in consiliis quibus cogitant.

68. A Demonstrative Pronoun in the same number, gender and case as the relative pronoun may be inserted in a relative clause in imitation of the Heb. The Heb. relative $2 \times-i$ is invariable in form and has a personal pronoun in apposition to it to show its relationship to the sentence.

Beatus vir, cujus est nomen Domini spes ejus.... Blessed is the man whose hope is in the name of the Lord....

Ps. xxxix, 5.

Quem Dominus Jesus interficiet spiritu oris sui, et destruet illustratione adventus sui eum. 1Whom the Lord Jesus will slay with the breath of his mouth, and destroy with the brightmess of his coming.

See also Pss. xviii, 4, xxxii, I 2, 1xxiii, 2, cxlv, 5 .

II Thess. ii, 8.

69. The Interrogative Pronoun quis may take the place of either a noun or an adjective.

When it is a true pronoun it has the form quis (qui), quae, quid. 


\section{Pronouns-Indefinite, Reciprocal}

When it is a pronominal adjective it has the form qui (quis), quae, quod.

In the Vg. it may be used in place of the Interrogative uter= which of two.

Quem vultis vobis de duobus demitti? Which of the two do ye wish to be veleased for you?

Mt. xxvii, 2 I.

See also Mt. ix, 5, xxi, 3I ; I Cor. iv, 2I; Lucan, Pharsalia

i, I26. Quid may be used like the Gk. $\tau i$ to ask a question.

Quid hic statis tota die otiosi? Why do ye stand heve idle all the day?

Mt. $\mathrm{xx}, 6$.

Ut quid is used to translate the Gk. "ina $\tau i$ or $\epsilon i s \tau i$.

Ut quid enim libertas mea judicatur ab aliena conscientia? For why is my liberty judged of another man's conscience?

See also Mt. ix, 4, xxvi, 8.

I Cor. $\mathrm{x}, 29$.

69a. The Indefinite Pronoun quis, quae or qua, quid may be used to take the place of either a noun or an adjective.

It is used by itself in the Vg. to translate the Gk. ris.

Infirmatur quis in vobis? Is any among you sick? Jas. $\mathrm{v}, \mathrm{I}_{4}$.

See also Acts x, 47, xxvi, 3I; Rom. v, 7; I Cor. iv, 2.

The Relative pronoun is used instead of the Indefinite quisquis in imitation of Gk. ôs $\stackrel{*}{u}$.

Qui ergo solverit unum de mandatis istis minimis, et docuerit sic homines, minimus vocabitur in regno caelorum. Whosoever shall break one of these least commandments and shall teach men so, shall be called least in the kingdom of heaven.

Mt. v, I9.

Ne alicui is used in Lk. viii, 56 instead of the usual ut nutli.

70. The Reciprocal Pronoun which is expressed in Eng. by one another, and in $\mathrm{Cl}$. L. by alints alium, alter alterum, inter se is generally expressed in the Vg. by invicem which is treated as an indeclinable pronoun.

It may also be expressed by altevutrum.

Estote autem invicem benigni, misericordes, donantes invicem. But be ye kind to one another, pitiful, forgiving one another.

Eph. iv, 32.

Nolite murmurare in invicen1. Do not mumur one to another.

Orate pro invicem. Pray for one another. Jn. vi, 43 . Jas. v, I6. 
Non ergo amplius invicem judicemus. Let us not therefore judge one another any longer.

Rom. xiv, I3.

See also Jn. xiii, 35, xv, 17; Acts, xv, 39; Rom. xii, I6, xvi, I6.

Confitemini ergo alterutrum peccata vestra. Confess your sins one to another. Jas. v, I6.

Dicebant ad alterutrum. They weve saying one to another.

Mlk. iv, 40.

Id ipsum sapere in alterutrum. To thinh the same thing one with another.

Rom. xv, 5 .

Sec also Mk. iv, 40; Acts vii, 26.

71. Hujusmodi and ejusmodi are used in the Vg. with an ellipse of the noun which they should qualify, which makes them almost equivalent to a pronoun.

Hujnsmodi enim Christo Domino nostro non serviunt. For such men do not serve Christ ouv Lord. Rom. xvi, I8.

Pro hujusmodi gloriabor.... For such a one will I glovy....

II Cor. xii, 5 .

Adversus hujusmodi non est lex. Against such theve is no law.

Gal. v, 23.

Sec also Jn. viii, 5 ; Acts xxii, 22; Rom.xvi, I 8; I Cor. vii, 28.

\section{Verbs.}

MOOD.

72. Moods are forms which verbs assume to show the way in which the action or state denoted by the verb is to be regarded, i.e., if it is to be regarded as a statement, a command, a desire, or a thought.

The Indicative Mood (generally) makes a statement or asks a direct question.

The Imperative Mood gives a command, or expresses a wish.

The Subjunctive Mood expresses a thonght rather than a fact. It is used to give a command or express a wish directly in the third person and is often used in prolibitions and in hesitating or polite statements or wishes.

It is generally used in indirect commands and questions and in many kinds of subordinate clauses, especially those that express purpose or result.

The uses of the Subj. are so various and its use in Latin is often 


\section{Verbs-Tense}

so different from its use in English, that it is inadvisable to learn any English equivalent for it such as I may love, or I might love.

Very often it is translated by the Eng. Ind. The student must learn to translate it by observing its use in Latin.

The Infinitive Mood is really the dative or locative case of a verbal notn. It gets its name, which means "un-bounded," from the fact that it is not bounded like other parts of the verb by number and person.

The Participle is a verbal adjective.

The Gerund and Supine are verbal nouns.

\section{TENSE.}

73. The action denoted by a verb may be defined both as regards its time and as regards its state or progress.

Its time may be defined as past, present, or future.

Its state or progress may be regarded as

$\begin{array}{ll}\text { continuous or incomplete, } \\ \text { perfect } & \text { or complete, } \\ \text { simple } & \text { or indefinite. }\end{array}$

The combination of these ideas of time and state should produce nine different tenses.

Past $\left\{\begin{array}{ll}\text { continuous I was loving. } \\ \text { perfect } & \text { I had loved. } \\ \text { simple } & \text { I loved. }\end{array} \quad\right.$ Present $\left\{\begin{array}{l}\text { continuous I am loving. } \\ \text { perfect I have loved. } \\ \text { simple I love. }\end{array}\right.$

$$
\text { Future } \begin{cases}\text { continuous I shall be loving. } \\ \text { perfect } & \text { I shall have loved. } \\ \text { simple } & \text { I shall love. }\end{cases}
$$

Different forms to express all these combinations exist in Eng., but not in Latin.

The Latin tenses are arranged below in the same order as the Eng. tenses in the table above. The names commonly given to them in grammars are printed in capitals.

$\begin{array}{llc}\text { IMPERFECT } & \text { amabam. } & \text { (missing) } \\ \text { PLUPERFECT } & \text { amaveram. } & \text { PERFECT amavi. } \\ \text { PERFECT } & \text { amavi. } & \text { PRESENT amo. }\end{array}$

(missing)

FUTURE PERFECT amavero.

FUTURE amabo.

It should be noticed that the tense called the Perfect in Latin 
has to do the work of two dissimilar tenses:- the Past Simple and the Present Perfect.

If continuous action in present or future time has to be expressed in Cl. L. the Simple Present or Future must be used.

In Ecc. L. we see the development of tenses formed by a participle and part of the verb esse which are very similar in meaning and form to the Eng. Present Continuous and Future Continuous. See section 90.

74. The Present tense denotes either an action or state in progress in present time, or customary or repeated action in present time.

Filius hominis traditur in manus peccatorum. The Son of man is being betrayed into the hands of sinners. Mt. xxvi, 45 .

Domine, salva nos, perimus. Lord, save us, we are perishing. Mt. viii, 25.

Lampades nostrae extinguuntur. Our lamps are going out. Mt. $x x v, 8$.

Corrumpunt mores bonos conloquia mala. Evil communications cormpt good manners.

I Cor. xv, 33 .

Omnis arbor, quae non facit fructum bonum, exciditur et in ignem mittitur. Every tree that bringeth not forth good fruit is hewn down and cast into the fire.

Mt. vii, I9.

See also Mt. ix, I7.

75. Conative Present. As the Present tense denotes action in progress which is not necessarily complete, it may be used to denote action which is attempted or desired, but not performed.

Multa bona opera ostendi vobis ex Patre meo: propter quod eorum opus me lapidatis? I have shown you many good works from my Father: because of which of these do ye desire to stone me?

Jn. $x, 32$.

Evacuati estis a Christo, qui in lege justificamini; a gratia excidistis. Ye are separated from Christ, ye who desive to be justified by the law: ye have fallen from grace.

See also I Cor. vii, 28.

76. Historic Present. The Present tense is used in narrative to denote events in past time for the sake of vividness.

Et veniunt rursus Hierosolyma. And they come again to Jerusalem.

Mk. xi, 27.

77. The Present used for the Future. The Present is sometimes used colloquially in a Future sense. 


\section{Imperfect Tense}

Tempus meum prope est: apud te facio Pascha cum discipulis meis. My time is at hand: I will eat the Passover at thy house with my disciples.

IIt. xxvi, I8.

Descendat nunc de cruce, et credimus ei. Let him now come down from the cross, and we will believe him.

See also Lk. xix, 8; Jn. xxi, 23.

78. The Present of $t^{\prime} \rho \chi \epsilon \sigma \theta a$ which is used in a Future sense in the N.T. with reference to the Messiah, especially in the participle, is sometimes translated by the Future in the $\mathrm{Vg}$. or even by the Perfect. It may also be translated by a Present.

See Mt. xi, 3; Jn. vi, I4, xi, 27, xiv, 3 .

A very curious use of the Present among several Futures is found in Acts xxviii, 6. There is nothing to suggest it in the Gk.

79. The Imperfect tense denotes an action or state in progress in past time, or customary or repeated action in past time.

The Imperfect is a descriptive tense and denotes an action in progress or a state of things actually observed. Hence in many instances it does not differ in meaning from the Perfect. This is especially the case with the verb esse:

Dux erat and Dux fuit may mean practically the same thing, the former describes the condition, the latter only states it.

Et multi divites jactabant multa. And many rich men were casting in much.

Mk. xii, $4 \mathrm{I}$.

Ecce quomodo amabat eum. Behold how much he loved him. Jn. xi, 36 .

Petrus autem et Johannes ascendebant in templum ad horam orationis nonam. But Peter and John used to go up to the temple at the hour of prayer, the ninth hour. Acts iii, I. In Acts xii, 4-7 there are several examples of the use of the Imperfect tense and the contrasted use of the Perfect tense.

See also Mt. viii, 2 ; Lk. iii, Io, xv, I6; Eph. iv, 28.

80. Conative Imperfect. The Imperfect is sometimes used to denote an action in past time which was attempted or desired, but not periormed.

Et vocabant eum nomine patris ejus Zachariam. And they wished to call him by' the name of his father Zacharias.

See Acts vii, 26, xxvi, I I.

81. The Imperfect is also used to express a polite or hesitating wish which the speaker does not like to express directly.

Volebam et ipse hominem audire. I should like to hear the man my'self.

Acts Xxv, 22. 


\section{Future Tense}

Optabam enim ipse ego anathemra esse a Christo pro fratribus meis. I could wish myself accursed from Christ for the sake of my brethren.

Rom. ix, 3.

82. The Future tense denotes an action or state which is expected to take place in future time.

The context decides whether the action denoted by the verb is simple or continuous.

Pariet autem filium: et vocabis nomen ejus Jesum. For she shall bring forth a son: and thou shalt call his name Jesus.

Mt. i, 2 I.

Et in hoc gaudeo, sed et gaudebo. And in this I rejoice, yea $I$ will continue to rejoice.

Phil. i, I8.

83. The Future may have the force of an Imperative.

Relinque ibi munus tuum ante altare, et vade, prius reconciliare fratri tuo: et tunc veniens offeres munus tuum. Leave there thy gift before the altar, and go first and be reconciled to thy brother, and then come and offer thy gift.

Mt. v, 24 .

Et cum oratis, non eritis sicut hypocritae. And when ye pray, be not as the hypocrites.

See also Mk. xii, $3 I$.

84. The Perfect tense in Latin performs the functions of two tenses which are quite distinct in Eng. and Gk. These are the tenses which are commonly called the Past Simple (or Preterite) and the Perfect (or Present Perfect) in Eng., and the Aorist and Perfect in Gk.

The translation of the tenses in the $\mathrm{Vg}$. is generally very careful: the Imperfect represents the Gk. Imperfect and the Perfect the Gk. Aorist or Perfect in the Ind. mood.

The Aorist is used in Gk. far more frequently than the Perfect. The Perfect in Gk. denotes completed action. The Aorist Indicative generally denotes action in past time, but must often be translated into English by the form which is called the Perfect (the tense form made with the auxiliary verb have).

It would be impossible and confusing to go into the reasons for this here. Those who wish for further information on the point will find it in the author's Syntax of N.T. Greek.

The point to be remembered by the Latin student is that the Latin Perfect may be translated by either the English Past Simple or by the Perfect. 


\section{Perfect Tense}

The most suitable form to use is decided by the context in all cases. The Gk. original is not a safe guide.

Example of the Latin Perfect denoting simple action in past time.

Et veniens ad discipulos suos, vidit turbam magnam circa eos. And when he came to his disciples he saw a great crowd round them.

IIk. ix, I 4 .

Examples of the Latin Perfect denoting that the action of the verb is regarded as complete ${ }^{1}$ at the time of speaking, and that its results are regarded as still existing.

Bontum certamen certavi, cursum consummavi, fidem servavi. I have fought the good fight, I have finished the course, I have kept the faith.

II Tim. iv, 7 .

Sed potius ite ad oves quae perierunt donus Israel. But rather go to the sheep that have perished (or the lost sheep) of the house of Israel.

Mt. $x, 6$.

Omnium autem finis appropinquavit. But the end of all things is at hand.

I Pet. iv, 7 .

85. The Perfect is used to translate the Greek Timeless Aorist and expresses a general truth, an habitual action, or action at a time not defined. When so used it must be translated by the Present tense in English.

Exortus est enim sol cum ardore, et arefecit faenum, et flos ejus decidit, et decor vultus ejus deperiit. For the sum arises with its burning heat, and dries up the grass, and its flower falls, and the beauty of its shape perishes.

Jas. i, I I.

See also I Pet. i, 24 and the curious imitation of the Gk. in Wordsworth and White's text in Jn. xv, 6 .

Tu es filius meus dilectus, in te complacui. Thon art my beloved son, in thee I am well pleased.

MIk. i, II.

Calendas vestras, et sollemnitates vestras, odivit anima mea: facta sunt mihi molesta, laboravi sustinens. Your festivals and feasts my soul hateth: they are a trouble to me, I am weary to bear them.

Isa. i, I 4 .

1 When it is said that the action is regarded as complete this does not mean that it is regarded as ended, but only that it is regarded as brought to its apprepriate conclusion in such a way that its effects still remain in action. The tense when used in this sense has as much to do with present as with past time, as it describes the present result of a past action. It may sometimes be translated by an Eng. Present. 
86. The Pluperfect tense denotes an action or state completed in past time, or an action which took place before some point in past time referred to in the context, or which the speaker has in mind.

Et descendit pluvia, et venerunt flumina, et flaverunt venti, et irruerunt in domum illam, et non cecidit: fundata enim erat super petram. And the rain descended, and the floods came, and the winds blew, and they fell upon that house, and it fell not: for it had been founded upon a rock.

Mt. vii, 25.

Venit enim filius hominis salvare quod perierat. For the Son of man came to save that which had been lost. Mt. xviii, I I.

The force of the Perfect, Pluperfect and Imperfect tenses is seen in the following example:

Et vidit duas naves stantes secus stagnum: piscatores autem descenderant, et lavabant retia. And he saw two ships standing by the lake: for the fishermen had come down out of them, and were washing their nets.

Lk. v, 2.

87. The Future Perfect tense denotes an action or state which is regarded as completed at some point in future time which the speaker has in mind or which is referred to in the context.

It is used very frequently in Latin where in Eng. we use a Simple Future, a Present, or a Perfect.

His autem expletis, proposuit Paulus in Spiritu, transita Macedonia et Achaia, ire Hierosolymam, dicens: Quoniam postquam fuero ibi, oportet me et Romam videre. When this was ended Paul purposed in the Spivit, after he had passed through Macedonia and Achaia, to go to Jerisalem, saying: "After I have been there I must also see Rome." Acts xix, 2 I.

Nisi abundaverit justitia vestra plus quam Scribarum et Pharisaeorum, non intrabitis in regnum caelorum. Unless your righteousness exceed that of the Scribes and Phavisees, ye shall not enter into the kingdom of heaven.

Mt. $\mathrm{v}, 20$.

Si fuerint alicui centum oves, et erraverit una ex eis, nonne relinquet nonaginta novem in montibus...? If any man has a hundred sheep and one of them goes astray, does he not leave the ninety and nine in the mountains...?

Mt. xviii, I2.

88. It is used in indefinite relative clauses and in indefinite clauses of time and place, referring to future time. See sections I 54, I 5.5 . 


\section{Periphrastic Forms of Tenses}

Et in quamcumque domum intraveritis, ibi manete, et inde ne exeatis. And into whatever house ye enter, there remain, and go not forth from thence. Lk. ix, 4.

Qui enim voluerit animam suam salvam facere, perdet illam: nam qui perdiderit animam suam propter me, salvam faciet illam. For whoso wishes to save his soul shall lose it: but whoso shall lose his soul for my sake shall save it. Lk. ix, 24 .

Et beatus est qui non fuerit scandalizatus in me. And blessed is he who is not offended in me. Mt. xi, 6 .

See also Mt. xxvi, r3; Rom. xv, 24.

89. It is also used like the Future with the force of an Imperative.

Nihil tuleritis in via. Take nothing for the way.

Lk. ix. 3 .

See also Mt. xxvii, 4; Acts xviii, I 5 .

90. Periphrastic forms of tenses are formed in Ecc. L. as in Eng., by joining the appropriate tense of esse to the present participle.

Periphrastic Present formed from the Present tense of esse and the Present Participle.

Non enim sumus sicut plurimi adulterantes verbum Dei. For we are not as many adulterating the word of God.

II Cor. ii, I 7 .

Esto consentiens adversario tuo cito dum es in via cum eo. Agree with thine adversary quickly while thou art in the way with him.

Mt. v, 25 .

Periphrastic Imperfect.

Et erat plebs expectans Zachariam. And the people was expecting Zacharias.

Lk. i, $2 \mathbf{I}$.

Et erat tribus diebus non videns, et non manducavit neque bibit., And he was three days without sight, and did neither eat nor drink.

Acts ix, 9 .

Periphrastic Future.

Noli timere: ex hoc jam homines eris capiens. Fear not: from henceforth thou shalt be catching men. Lk. v, Io.

91. A Future tense is also formed from the Future Participle of esse with a clause introduced by $u t$ as its subject.

Futurum est enim ut Herodes quaerat puerum ad perdendum eum. For Herod will seek the young child to destroy him.

IIt. ii, I3. 
A Future Subj. is formed from the Future Participle and the Present Subj. of esse.

Nolite putare quia ego accusaturus sim vos apud Patrem. Do not think that I shall accuse you to the Father. Jn. v, 45 .

92. Periphrastic tenses formed with habeve and faceve.

The beginning of the periphrastic formation of tenses which resulted in the forms now used for the Future tenses in French and Italian is to be discerned in Ecc. L.

The use began in the employment of the verb habeve in its ordinary sense with an explanatory Inf. This is found in the Classics.

Adhuc multa habeo vobis dicere. I have yet many things to say to yout.

Jn. xvi, I2.

Quia non habent retribuere tibi. Because they have not (anything) whence to pay you back.

Hence arises a sense of futme necessity:

Baptismo autem habeo baptizari. But I have a baptism with which I must be baptised.

Lk. xii, 5 o.

Habes, homo, imprimis aetatem venerare aquarum, quod antiqua substantia. First, O man, you must venerate the age of water; because it is an ancient substance. Tert. de Bapt. iii.

Aquas video quas videbam quotidie: istae me habent mundare in quas saepe descendi, et nunquam sanatus sum. I see water which I was used to see every day: it has got to cleanse me, though I have often gone down into it, and I have never been cleansed.

Ambrose, de Mysteriis, iv, I9.

93. Habeve is also found as an auxiliary verb with a past participle-a construction which became the normal way of expressing the pluperfect tense in Italian and French ${ }^{1}$.

Tantum autem auditum habebant... Only they had heard....

Gal. i, 23.

94. The Infinitive is used with the verb faceve in the sense of causation.

Et adduxerunt asinam et pullum, et imposuerunt super eos vestimenta sua, et eum desuper sedere fecerunt. And they brought the ass and the colt and put on them their clothes, and they made him sit thereon.

Mt. xxi, 7 .

"Compare "De numero eorum omnia se habere explorata," Caesar, B.G., II. 4. I. 


\section{Sequence of 'Tenses-Voice}

95. The sequence of tenses. The Present, Future, Future Perfect and Perfect (when translated by the English Perfect formed with the auxiliary have) are called Primary tenses.

The Imperfect, Pluperfect and Perfect (when translated by the English Past) are called Secondary tenses.

When the verb in a principal clause is in a Primary tense, a verb in the Subj. mood in a subordinate clause is in a Primary tense in certain kinds of clauses.

When the verb in a principal clause is in a Secondary tense, a verb in the Subj. mood in a subordinate clause is in a Secondary tense in certain kinds of clauses. This rule is not strictly observed in Ecc. L.

\section{VOICE.}

96. The Active voice is used when the subject of the verb is spoken of as acting or doing something.

The Passive voice is used when the subject of the verb is spolien of as suffering or being acted upon. Only Transitive verbs can have a passive voice.

There are certain verbs such as to fall and to die which do not speak of the subject as acting, but which are regarded as being in the active voice because they are Intransitive.

97. Certain verbs in Latin are passive in form, but active in meaning. These are called Deponent verbs because the old grammarians thought that they had laid aside a passive and assumed an active meaning.

A few verbs such as gaudeo, -ere, gavisus sum have the deponent form only in the Perfect, Pluperfect and Future Perfect tenses. These are called Semi-deponent verbs.

\section{THE USE OF THE IMPERATIVE MOOD. THE SUB- JUNCTIVE MOOD IN PRINCIPAL CLAUSES.}

98. The Imperative Mood is used to express commands and entreaties in the second person singular or plural, and has forms which may be used to express a command given in the third person.

Sed, si quid potes, adjuva nos. But, if thou canst do anything, help us.

Mk. ix, 22.

Dixit ergo Jesus: Facite homines discumbere. Thevefore Jesus said: Make the men sit down.

Jn. vi, ro. 
In Ecc. L. the second person of the Present Subj. is used to express a command or entreaty.

Nec doleas, quod talem amiseris, sed gaudeas, quod talem habueris. Do not grieve because you have lost such a man, but rejoice because you had him.

Jerome, Ep. 60.

The Present Subjunctive is generally used to express a command or entreaty in the first or third person. This use of the Subj. is called the Jussive Subjunctive.

Nam Dens dixit: Honora patrem et matrem; et: Qui maledixerit patri vel matri morte moriatur. For God said: Honour thy father and mother; and: If any curse his father or his mother, let him surely die.

Sometimes sine or sinite = allow is prefixed to the Subj.

Sine ejiciam festucam de oculo tuo. Let me cast out the mote out of thine eye.

Mt. vii, 4 .

99. Prohibitions are negative commands or entreaties. The Imperative is not used in prohibitions, except in poetry.

Prohibitions are expressed in prose:

(I) By noli or nolite followed by an Inf.

(2) By ne (or non in Ecc. L.) followed by the Perfect Subj.

(3) By ne or non followed by the Present Subj. Subj.

(4) By vide followed by a negative and the Present or Perfect

The first two methods are regularly used in $\mathrm{Cl}$. prose. The last two are often found in Ecc. L.

(I) Noli vexare illum. Trouble him not.

Lk. viii, 49.

Nolite dare sanctum canibus, neque mittatis margaritas vestras ante porcos. Do not give that which is holy to the dogs, and do not cast your pearls before swine. Mt. vii, 6 .

(2) In viam gentium ne abieritis, et in civitates Samaritanorum ne intraveritis. Go not into the way of the Gentiles, and into the cities of the Samaritans enter ye not. Mt. $\mathrm{x}, 5$. Nihil feceris tibi mali. Do thyself no harm. Acts xvi, 28.

(3) Nec vocemini magistri. Be not ye called masters.

Mt. xxiii, ro.

Non mireris quia dixi tibi: Oportet vos nasci denuo. Marvel not that I said to thee: Ye must be borm again. 


\section{In principal Clauses}

Qui furabatur, jam non furetur, magis autem laboret. Let him that stole steal no more, but vather let him labour.

Eph. iv, 28.

(4) Videte ne contemnatis unum ex his pusillis. See that ye despise not one of these little ones.

Mt. xviii, ro.

Vide nemini dixeris. See thou tell no man. Mt. viii, 4.

100. An emphatic and absolute prohibition may be expressed by omnis and a verb in the Present Subj. negatived by non in imitation of Heb.

Omnis sermo malus ex ore vestro non procedat. Let no corrupt speech proceed out of your mouth. $\quad$ Eph. iv, 29.

101. Hortatory Subjunctive. Besides expressing commands the Subj. may express an exhortation or a wish.

Transeamus usque Bethleem, et videamus hoc verbum quod factum est. Let us go to Bethlehem and see this thing which has come to pass.

Lk. ii, I5.

In expressing a wish the Present Subj. denotes that the wish is still possible, the Imperfect Subj. or Pluperfect Subj. that it is unaccomplished in present time, or in certain cases that it is impossible. Utinam is often used before the Past tenses of the Subj. when they express an unaccomplished wish.

Sanctificetur nomen tuum: adveniat regnum tuım. Hallowed be thy name: thy kingdom come. Mt. vi, 9.

Utinam fuisset dominus meus ad prophetam, qui est in Samaria. Would that my master weve with the prophet who is in Samaria. II Kings v, 2.

Utinam frigidus esses aut calidus. Would that thou wert cold or hot. Rev. iii, I5; I Cor. iv, 8.

102. Deliberative Subjunctive. In Cl. L. the Subj. is used in deliberative questions when a person asks himself or another what he is to do.

In Ecc. L. the Future or the Present Ind. is also often used in this sense.

Subj. Euntes emamus denariis ducentis panes? Ave we to go and buy two hundred pennyworth of bvead?

Mk. vi, 37 . Fut. Quid faciemus et nos? What shall we do? Lk. iii, I4. Pres. Ind. Tu es qui venturus es, an alium expectamus? Avt thou he that should come, or are we to look for another? Mt. xi, 3 . 


\section{Infinitive Mood}

103. Potential Subjunctive. The Subj. is used to express an action which is not regarded as actual, but only as possible or conceivable. Expressions of this kind may be regarded as the apodoses ${ }^{1}$ of conditional sentences where the condition is not expressed. The Subj. is rarely used in this sense in the Vg.

Profecto curasset eum a lepra, quam habet. Surely he would cure him of the leprosy which he has. II Kings v, 2.

Vix enim pro justo quis moritur: nam pro bono forsitan quis audeat mori. For scarcely for a just man does one die, but perhaps for a good wan one would dare to die. Rom. v, 7 .

Vellem autem esse apud vos modo, et mutare vocem meam. But I should like to be among you now and to change my tone.

See also Mt. xxv, 27.

Gal. iv, 20.

The above uses of the Subj. are the only ones which occur in independent sentences and principal clauses.

\section{NOUN CLAUSES.}

The iMPORTANCE OF DISTINGUISHING BETWEen DIFFERENT SENSES OF THE SAME WORD.

104. Many of the difficulties that beginners find in mastering a foreign language arise from the fact that they do not consider the meaning of some of the words that most frequently occur, but look only at their form.

Some of these words which are in common use are employed in several totally different senses.

Take for example the Eng. word that. It may be

(I) A Demonstrative Pronoun or Adjective trans. by the Latin ille, etc.

Give me that. Da mini illud.

I sce that woman. Illam mulierem video.

(2) A Relative Pronoun trans. by Latin qui, etc.

I have the book that you bought. Librum, quem emisti, habeo.

I see the man that sent for me. Virum, qui me arcessivit, video. Latin $u t$.

(3) A Conjunction introducing a clause of purpose trans. by

I came that I might see you. Ut te viderem, veni.

(4) A Conjunction introducing a clause of consequence trans. by Latin $u t$ or ita $u t$.

1 See section 167. 


\section{Various Senses of the Same Word}

The storm was so great that the ship was wrecked. Tanta erat procella, ut navis demergeretur.

(5) A Conjunction introducing a noun clause which is trans. either by the Acc. and Inf. construction, or by a clause introduced by $u t$, or in Ecc. L. by quod, quia or quoniam.

He said that my brother had come. Fratrem meum venisse dixit.

It is expedient that I slould do this. Expedit ut hoc faciam.

He prayed that the Lord would send labourers into the harvest. Rogavit ut Dominus operarios in messem ejiceret.

We know that you speak the truth. Scimus quia vera dicis.

The constructions mentioned in sub-section 5 are explained in the following pages. The object of the above paragraph is to warn the student not to confuse the noun clauses, now to be described, with the adverbial clauses described in sections $157-165$.

As the Eng. word that is used in so many entirely distinct senses, it is obviously most essential to be certain of its meaning before trying to translate it into Latin.

Take for example the sentences:

I know that that that that man says is true. Vera esse scio ea, quae ille dicat.

He told me that he went to Rome that he might see Caesar. Dixit mihi se Romam adivisse, ut Caesarem videret.

The great difference between Eng. and Latin is obvious from these examples.

105. While this question of words with similar forms having widely different meanings is being discussed, it will be well to refer to the Latin words which present a similar difficulty.

These are $u t, c u m$, quod.

$U t$ when it introduces a clause with the verb in the Indicative mood means either as, when or where according to the context.

The clause that it introduces is either a clause of comparison, a 3 clause of time, or a clause of place. See sections $153-155$, I 75 .

When $u t$ introduces a clause with the verb in the Subjunctive mood the clause may be:

(I) A clause of purpose. See sections I $_{57},{ }_{5} 8$.

(2) A clause of consequence. See section 163 .

(3) A noun clause. See sections I I6-I 27, I 42, I 45.

In all these cases $u t$ is translated by that in Eng. 


\section{Various Senses of the Same Word}

Example:

Et factum est ut discesserunt ab eis angeli in caelum, pastores loquebantur ad invicem.... And it came to pass when the angels were gone away from them into heaven, the shepherds were saying one to another...

Lk. ii, I 5 .

In the following example $u t$ is first used to introduce a clause of purpose and secondly a clause of comparison.

Non ut confundam vos haec scribo, sed ut filios meos carissimos moneo. I do not write these things that I may confound you, but as my beloved sons I warn you. I Cor. iv, I4.

In the following example $u t$ is used first to introduce a noun clause, in the second place to introduce a clause of consequence, in the third place to introduce a clause of comparison.

Orantes simul et pro nobis, ut Deus aperiat nobis ostium sermonis ad loquendum mysterium Christi, propter quod etiam vinctus sum, ut manifestem illud ita ut oportet me loqui. Praying at the same time for us also, that God would open to us a door of utterance to speak the mystery of Christ, for which also I am bound, that I may make it manifest as I ought to speak. Col. iv, 3 .

Cum may be either a preposition meaning together with or a conjunction introducing a clause of time, a clause of cause, or a clause of concession and trans. when, since, although. See sections I 53, I 54, I 56, I 66,2 IO.

In old Latin books cum when used as a conjunction is generally spelt quum. In books recently printed it is spelt cum or quom.

Quod may be either the neuter singular of the relative pronoun or a conjunction introducing a clause of cause and trans. because, or (in Ecc. and late Latin only) a conjunction introducing a noun clause. See section I56. A careful study of the context is often needed to find out whether quod is a relative pronoun or a conjunction.

The Infinitive Mood and its equivalents.

106. The so-called Infinitive Mood had its origin in the Dat. or Loc. case of a verbal noun. Habere meant originally for having or in having. In early Latin the Dat. sense of the Inf. was still obvious, for it was used to express purpose. 


\section{The Infinitive Mood}

Reddere hoc, non perdere, erus me misit. My master sent me to veturn (for returning) this, not to lose it. Plautus, Ps. 642.

Nec dulces occurrent oscula nati

Praeripere. Nor will your sweet children vun to you to snatch your kisses.

Lucretius, iii, 895 .

This usage apparently held its ground in vernacular Latin, and appears occasionally in the Augustan poets who would be encouraged to use it by the analogy of the use of the Inf. in Gk. to express purpose.

Nos numerus sumus, et fruges consumere nati. We are a mere collection of nonentities, born to devour the fritits of the earth.

This use of the Infinitive never occurs in Classical Latin prose. Its place is taken by a clause introduced by $u t$, or by one of the other const. mentioned in sections $157-162$.

In Ecc. L. the Inf. is frequently used to express purpose.

107. In Cl. L. the Inf. is treated as the Nom. or Acc. case of a verbal noun. Its Dat. sense is generally ignored.

In the same way, although the Eng. Inf. is generally found with the preposition to in front of $i t$, this preposition is no part of the Inf., and is omitted after certain verbs such as may, can, shall, bid, let, make.

Examples: I can do this. Let me go. Make him stay. I will say what I like. I bid you come here.

Contrast these with: I am able to do this. Allow me to go. Force him to stay. I intend to say what I like. I command you to come here.

The omission or insertion of the preposition to before the Inf. is quite arbitrary: it contributes nothing to the meaning of the phrase.

In such a sentence as: To err is human, to forgive divine, the Infs. are treated exactly as if they were verbal nouns standing as the subjects of the clauses: the preposition to is absolutely without meaning.

The preposition only has its proper force when the Inf. is used to express purpose or result, or is used in an explanatory sense. Examples: I came here to fish. I am tall enough to look over your head. It is time to go home. Even in this use the force of the preposition is so little felt that another preposition may be inserted in front of it. Example: What went ye out for to see?

N.E.L. 
108. The Infinitive partakes of the nature both of a verb and a noun.

As a verb it has a subject, expressed or understood; if it is the infinitive of a transitive verb, it has an object: it governs the same case as the verb from which it is derived; it is qualified by adverbs: it has tense and voice.

As a noun it can be used as the subject or object of a sentence, , or it may stand in apposition to another noun: but in Latin it cannot be governed by a preposition.

The subject of an Inf. is in the Accusative Case. The reason for this will be explained later.

The fact that the Inf. is a verbal noun caused it to be used in noun clauses.

109. In Cl. L. the Inf. with its subject in the Acc. (called the Accusative and Infinitive Construction) is regularly used in object clauses standing as objects of verbs denoting saying and thinking.

There are however two other constructions that are in some sense equivalent to the Acc. Inf. construction in noun clauses.

These are

(I) A clause introduced by wt with the verb in the Subj. (called ut with the Subjunctive construction).

(2) A clause introduced by quod, quia, quoniam with the verb in the Ind. or Subj. (called quod, quia, quoniam construction).

This latter construction only occurs in Ecc. L. with very few exceptions mentioned below.

The use of these constructions is described in the following sections. A few words may be said here about their origin.

110. The ut with the Subjunctive construction is most frequently found in object clauses depending on verbs meaning to command. to request, to bring about, etc.

Examples:

Ut hoc facias tibi impero.

Te rogo ut milhi subvenias.

Effecit ut ex urbe exirent.

It is easy to see that there is something of a sense of purpose or desired result in the clauses introduced by $u t$.

The meaning of these sentences might be expressed as follows:

I give a command to you in order that you may do this. 


\section{Ut with Subjunctive and "quod" Constructions 5I}

I make a request to you in order that you may help me.

He brought it about with the result that they went out of the city.

As is explained in sections $\mathrm{I}_{57}, \mathrm{I} 63$ clauses introduced by $u t$ with a verb in the Subj. mood denote both purpose and result.

111. The ut with the Subjunctive construction is however found in other noun clauses, especially in clauses which are the subjects of impersonal verbs or of the verb to be.

In some of these no sense of purpose or result can be discovered. It seems as if this construction were used as a substitute for the Inf., just as the "wa with a Subjunctive construction is used in later Gk.

Example:

Expedit vobis ut ego vadam. It is expedient for you that I go away.

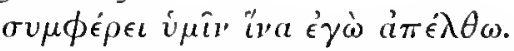

J11. xvi, 7 .

This construction is quite $\mathrm{Cl}$, and goes back to the beginning of the language, as far as we know it.

112. The quod, quia, quoniam construction however is not $\mathrm{Cl}$. It seems to have taken its rise during the decadence of the language, and it is quite certain that its prevalence is due to slavish imitation of the Gk. original on the part of those who translated the Septuagint and the N.T. into Latin.

It is so common in Ecc. L., and so characteristic of it, that its origin must be treated at length.

113. Clauses introduced by the neuter relative quod referring to a noun or pronoun (expressed or understood) in the main clause, are used in $\mathrm{Cl}$. I. in a sense approximating to that of a noun clause in apposition. Although these clauses serve to explain the signification of the noun or pronoun to which they refer, just like a noun in apposition, they do not necessarily agree with it in case or gender.

Haec res mihi curae est, quidnam hoc sit negoti, quod filia repente expetit ex me, ut ad se irem. This is what worries me, what can be the reason that my daughter suddenly asks me to go to her.

Plaut. Men. 762 .

Accidit perincommode, quod eum nusquam vidisti. It happens most awkwardly that you have never seen him.

Cic. Ep. ad Att. i, 17. 


\section{Origin of "quod" Construction}

Hoc scio quod scribit nulla puella tibi. This I do know that no givl writes to you.

Mart. xi, 64.

Hoc uno praestamus vel maxime feris, quod exprimere dicendo sensa possumus. In this one thing we surpass the beasts most of all, namely that we can express our thoughts in speech.

Cic. Or. i, 8.

There are two examples in early Latin where a clause introduced by quod stands as the object of a verb of saying or feeling. The verb is in the Subj.

Equidem scio jam filius quod amet meus istanc meretricem.

Truly I know now that my son loves that harlot. Plaut. As. $5^{2}$. The other example is in Cato the Elder.

This construction also occurs in the book on the Spanish war, written by a follower of Caesar in an uncultivated style, in Suetonius, Apuleius and Tacitus, but only very rarely.

In later writers it becomes more and more common.

Examples:

Renuntiaverunt quod Pompeium in potestate haberent. They announced that they had Pompey in their power.

Bell. Hisp. 36 .

Titus, recordatus quondam super cenam quod nihil cuiquam toto die praestitisset.... Titus, remembering once during supper that he had given nothing to anyone during the whole day....

Suetonius, Titus.

Qui puellae nuntiaret quod eam juvenis vocaret ad se... Jho was to tell the ginl that the young man called her to him....

Apuleius $\mathrm{x}$.

See also Tacitus, Ann. xiv, 6 .

The usual opinion about this construction is that it is a vernacular idiom, ignored by the $\mathrm{Cl}$. writers, which came into common use during the decay of the language.

Madvig however thinks that, if this had been a vernacular idiom, it would have occurred more frequently in Plautus. He prefers to connect it with the use of quod in apposition mentioned above, and regards the passages in Plautus and Cato as possibly corrupt.

114. However this may be, the use of this construction received a great extension in the Old Latin version of the Bible and is quite common there as well as in the Ecclesiastical writers, who were 


\section{Origin of "quod" Construction}

naturally much influenced in their style by the version of the Bible which they used.

In the Bible and in these writers both the Ind. and Subj. moods are used indifferently in this construction.

The reason why the translators of the Bible made so much use of this construction is that there is in $\mathrm{Gk}$. an alternative construction to the Acc. and Inf. construction used after verbs of saying or thinking. This consists of a clause introduced by ör८ with the verb in the Ind. mood. In certain of its uses ot $\iota$ corresponds to the Latin quod, and the translators, who strove to translate the Gk. as literally as possible, eagerly seized upon the construction with quod which was coming into use in Latin to translate clauses introduced by $\tilde{\tau} \tau$.

They also kept the mood of the Gk. original in some cases, although this was quite contrary to Latin usage.

They did even more than this. ¿̈r also means becanse in Gk., and there are two Latin words that can be used to translate it literally in this sense, namely quia and quoniam.

These words were therefore used to translate ot $t$ when introducing an object clause after a verb of saying or thinking exactly as quod was used.

There seems to be a certain approximation to this use in the lines of Catullus:

Id gratumst mihi, me quoniam tibi dicis amicum,

Muneraque et Musarum hinc petis et Veneris.

This is pleasing to me, that you call me your friend and seek the gifts of Venus and the Muses from me.

lxviii, 8 . where quoniam picks up and explains $i d$ just as quod did in the examples in section I I 3 .

Some usage of this kind in familiar speech may have served to help the introduction of this form of expression; but it must have made the early versions of the Bible sound very strangely to educated ears.

However this usage spread from these versions to all Ecclesiastical writers, even to Tertullian and Cyprian, although they employ it sparingly. Generally speaking this construction is employed by the early Fathers in those parts of their writings which were intended for partly educated people, or which deal directly with the Bible.

Jerome retained it in his revised version of the Bible, which we 
call the Vulgate, even in the O.T. which he translated anew from the Hebrew, although he modified some of the extreme literalness of the old versions.

115. The use of clauses introduced by quod was widely extended in later Latin to cover most of the senses that had been expressed in Cl. L., and even in the early Fathers, by an Acc. Inf. or a clause introduced by $u t$.

From these uses descend the many uses of que in French and che in Italian.

It should be noticed how much nearer the general construction of Eng. is to the style of Ecc. L. than to that of Cl. L.

Eng. is not derived from Latin except in respect of a great part of its vocabulary; but there is no doubt that the general structure of Eng. has been largely modified by the style of the English Bible of I6rI, the style of which was in its turn influenced by the Vg.

Examples of noun clauses introduced by quod, quia, quoniam are given in section 135 .

\section{The InfINITIVE OR ITS EQUIVALENTS USED AS THE SUBJECT OR COMPLEMENT OF A VERB.}

116. The Simple Inf., an Acc. and Inf., a clause introduced by ut, or (in Ecc. L. only) a clause introduced by quod, quia, quoniam is used as the subject of impersonal verbs and in many expressions containing the verb esse.

The usage varies with different periods of the language and with different writers; the student must learn the construction of the various verbs by experience.

In Eng. the syntax of sentences of this kind is confused by the fact that they are written in the following forms:

It is more blessed to give than to receive.

It is expedient that one man should die for the people.

The real subject of the first of these sentences is to give than to receive.

The real subject of the second sentence is that one man should die for the people.

The word it in each sentence is the Preparatory Subject, and the sentences are written in this way in Eng., because, in that language, the subject is nearly always put first in the sentence. 


\section{Infinitive etc. as Subject}

Indeed, this is the only way in which the subject can be distinguished from the object in Eng. owing to the absence of case endings. The Preparatory Subject serves to give notice that the real subject is coming afterwards.

In many Latin grammars impersonal verbs are said to take an Infinitive, or a clause with ut and the Subj. after them.

This confuses the student who may think that these clauses come after the verbs as objects, whereas they are really subjects.

117. A Simple Inf. may be used in Latin, as in Eng., as the subject of a verb, especially of the verb to be.

As Subject:

Beatius est magis dare quam accipere. It is move blessed to give than to receive.

Acts $\mathrm{xx}, 35$.

Mihi vivere Christus est, et mori lucrum. To me to live is Christ, and to die is gain.

Phil. i, 2 I.

117a. A Simple Inf. may be used in Latin as in Eng. as the complement of a verb, especially of the verb to be.

Hoc est praeceptum Dei facere, hoc est voluntatem Patris adimplere. This is to perform the commandment of God: this is to fulfil the will of the Father.

Cyprian.

See the whole selection Quid est voluntas Dei in the Appendix, p. II9, for examples of the use of the Simple Inf.

118. The verb oportet generally has an Acc. and Inf. as its subject.

Illum oportet crescere, me autem minui. He must increase, but I'must decrease.

Jn. iii, 30 .

Oportet Deo obedire magis quam hominibus. It is necessary for us to obey God, vather than men.

Acts v, 29.

But it may take a clause introduced by quod in Ecc. L.

Oportet quod verbum Dei in nobis manens continue meditemur. We onght continually to meditate on the word of God which abides in us.

T. Aq. de Symb. Ap.

119. We may here notice a peculiar idiom which is also found in Cl. L., namely to use a Past tense of the verb oportere with a Present Inf. 
as its subject to express an unfulfilled duty. This is expressed in Eng. by the use of a Past Inf.

Haec oportuit facere, et illa non omittere. These ye ought to have done, and not to have left the other undone.

Mt. xxiii, 23.

Oportuit ergo te mittere pecuniam meam nummulariis, et veniens ego recepissem utique quod meum est cum usura. Thou oughtest to have put my money to the bankers, and then at my coming I should have received my own with usury.

Mt. xxv, 27.

See Acts xxiv, 20.

A Past tense of oportere may have however simply a past sense without any idea of unfulfilled duty.

Oportebat autem eum transire per Samariam. But he had to go through Samaria.

Jn. iv, 4; Lk. xv, 32.

120. Other impersonal verbs may have either a clause introduced by $\imath t$ or an Acc. Inf. for subject. In some cases $u t$ is omitted and a Simple Subj. with its subject, etc. forms the noun clause. The use of Ecc. writers varies much from that of $\mathrm{Cl}$. writers and no exact rule can be laid down.

121. The expression factum est to represent the Gk. é $\gamma \dot{v} \nu \in \tau o$, which in its turn represents the Heb. "? is very frequent in the $\mathrm{Vg}$. and is generally translated it came to pass. It is not $\mathrm{Cl}$.

It generally has for its subject a clause introduced by $u t$, but it may have an Acc. and Inf. or even a clanse with the verb in the Ind. and no connecting particle.

Factum est autem et in alio Sabbato, ut intraret in synagogam, et doceret. And it came to pass on another Sabbath that he entered into a synagogne and taught.

Lk. vi, 6.

Factum est autem revertenti mihi in Hierusalem, et oranti in templo, fieri me in stupore mentis. And it came to pass that when I had returned to Jerusalem and was praying in the temple, $I$ was in a trance.

Acts xxii, I 7 .

See Acts xvi, I6.

Factum est autem in illis diebus, exiit in montem orare. And it came to pass in those days that he went out into a mountain to pray.

Lk. vi, I2.

122. Accidit, contigit, expedit, pertinet. In $\mathrm{Cl}$. L. the subject clause is constructed with $u t$.

The Acc. and Inf. constr. is found in the Vg., or the Subj. with ut omitted, or quia with Ind. 


\section{Infinitive etc. as Subject}

Accidit autem ut sacerdos quidam descenderet eadem via. But it happened that a certain priest was going down by the same way.

Lk. $x, 3 I$.

Et cum iter faceret contingit ut adpropinquaret Damasco. And when he was travelling it happened that he drew near to Damascus.

Acts ix, 3 .

Expedit vobis ut ego vadam. It is expedient for you that $I$ go away.

Jn. xvi, 7 .

Contigit autem patrem Publii...jacere. But it happened that the father of Publius lay sick.

Acts xxviii, 8.

Et contigit, dum iret, a turbis comprimebatur. And it happened that while he went he was pressed by the crowds.

Lk. viii, 42 .

123. Necesse est, decet. The subject clause is constructed either with the Acc. and Inf. or with $u$ t.

Unde necesse est et hunc habere aliquid quod offerat. Whence it is necessary that he should have something to offer.

Heb. viii, 3 .

Necesse est enim ut veniant scandala. It must needs be that offences come.

Mt. xviii, 7 :

I Thess. i, 8; Heb. vii, I2; Heb.ix, I6: (ut omitted).

Sine modo, sic enim decet nos implere omnem justitiam. Suffer it to be so now, for thus it becomes us to fulfil all righteousness.

IIt. iii, I6.

Talis enim decebat ut esset nobis pontifex. For it was befitting that there should be such a high priest for us.

Heb. vii, 26.

124. Licet and placet have a Simple Inf. for subject with a dative of the person to whom the action is allowable or pleasing. The $u t$ clause is also used.

Non licet mittere eos in corbanan. It is not lawful to put them into the treasury. Mt. xxvii, 6.

See also Mt. xxii, I 7 .

Placuit nobis remanere Athenis solis. It pleased us to remain in Athens alone.

I Thess. iii, I.

Cum placuit ei...ut revelaret Filium suum in me. When it pleased him...to reveal his Son in me.

Gal. i, I5. 
125. Interest is only used once in the N.T. and has its peculiar construction of an Abl. feminine of the possessive pronoun to express the person in whose interest the action takes place.

Quales aliquando fuerint, nihil mea interest. Whosoever they were makes no matter to me.

Gal. ii, 6.

The following are examples of the use of quod and quia in subject clauses:

Non ad te pertinet quia perimus? Doth it not matter to thee that we perish?

Mk. iv, 38 .

Latet enim eos hoc volentes, quod caeli erant prius. For this they are willingly ignorant of, that the heavens were of old. II Pet. iii, 5 .

126. An impersonal predicate made up of a neuter adjective and the verb esse may have either a Simple Inf. or Acc. and Inf. or a clause introduced by ut (or in Ecc. L. by quod, etc.) as its subject.

Non est vestrum nosse tempora vel momenta, quae Pater posuit in potestate sua. It is not yours to know times and seasons which the Father put in his own power. Acts i, 7 .

Facilius est enim camelum per foramen acus transire, quam divitem intrare in regnum Dei. For it is easier for a camel to go through the eye of a needle than for a rich man to enter into the kingdom of God.

Lk. xviii, 25.

Bonum est enim mili magis mori, quam ut gloriam meam quis evacuet. For it is better for me to die than that anyone should make my glory vain.

I Cor. ix, I5.

Reliquum est, ut et qui habent uxores, tanquam non habentes sint. It remains that those that have reives should be as if they had none.

I Cor. vii, 29.

Manifestum est quod regnum mundi non est per multos deos, sed per unum tantum. It is plain that the government of the world is not through many gods, but through one only.

Thos. Aq. Symb. Ap. iv.

127. A clause introduced by $u t$ (or in Ecc. L. by quod, etc.) may form the subject of any verb used impersonally whether in the Active or the Passive voice.

Ascendit in cor ejus ut visitaret fratres suos, filios Israel. It came into his heart to visit his brothers the children of Israel. Acts vii, 23. 


\section{Infinitive etc. as Complement}

Hic jam quaeritur...ut fidelis quis inveniatur. Here it is expected that a man be found faithful.

I Cor. iv, 2.

Sic ergo patet quod multum utile est habere fidem. So then it is plain that it is very profitable to have faith.

Thos. Aq. Symb. Ap. i.

\section{The Infinitive OR ITS EQUivalents USED to COMPLETE THE MEANING OF CERTAIN VERBS.}

128. Certain verbs which are generally the same in Latin as in Eng. are followed by an Inf. to complete their meaning. These are sometimes called Modal verbs because they add new modes of expression or moods to the verbs to which they are attached.

The most important are possim, volo, nolo, malo, and also verbs denoting beginning or ceasing, habit, continuance, desire, purpose, aim or duty.

If the subject of the principal verb is the same as that of the Inf. the subject of the Inf. is often not expressed, it is however generally speaking in the Nominative case and any adjectives that agree with it must be in that case; see example 2 .

If the subject of the Inf. is not the same as the subject of the principal verb, the subject of the Inf. is in the Acc. case; see example 3 .

In Ecc. L. a clause introduced by $u t$ with the Subj., or a Subj. without $u t$, or even an Ind. may take the place of the Inf. after volo.

Quomodo potest homo nasci, cum senex sit? How can a man be born when he is old?

Jn. iii, 4.

$\mathrm{Si}$ vis perfectus esse, vade, vende quae habes. If thou wishest to be perfect, go and sell what thou hast. Mt. xix, 2I.

Volo ergo viros orare in omni loco. I zeish therefore men to pray in every place.

I Tim. ii, 8.

Omnia ergo quaecumque vultis ut faciant vobis homines, et vos facite eis. Whatsoever things therefore that ye wish men should do unto you, do ye also unto them.

Mt. vii, I2.

See also Jn. xvii, 24; Mt. xx, 32 .

Ubi vis paremus tibi comedere Pascha? Where dost thou wish us to prepare for thee to eat the Passover? Mt. xxvi, I7.

Vis imus et colligimus ea? Dost thou wish us to go and gather them up?

Mt. xiii, 28. 
Et iterum coepit docere ad mare. And he began again to teach by the sea.

Mk. iv, I.

Ut cessavit loqui, dixit ad Simonem.... When he ceased to speak, he said to Simon....

Lk. v, 4 .

Per dicm autem festum dimittere solebat illis unum ex vinctis. On the feast day he was wont to release to them one of the prisoners.

Mk. xv, 6.

\section{The Infinitive or its equivalents Used AS THE OBJECT OF A VERB.}

129. The Simple Inf. may be used as the object of a verb, just like a noun.

Perficere autem non invenio. But how to perform it I find not.

Rom. vii, I8.

129a. The Inf. may be used as one of two objects after certain verbs such as docere, jubere, and in Ecc. L. rogare.

Docnerunt enim linguam suam loqui mendacium. For they tanght their tongue to speak a lie.

Jussit milites descendere, et rapere eum de medio eorum. He commanded the soldiers to go down and to take him from the midst of them.

Acts xxiii, Io.

Propter quod rogo vos accipere cibum pro salute vestra. Wherefore I ask you to take food for your health's sake.

Acts xxvii, 34 .

The Inf. may be retained as object after a passive verb of this kind.

Ubi inventis fratribus rogati sumus manere apud eos dies septem. Where having found brethren, we were asked to remain with them seven days.

See also II Cor. x, 2, 9 .

Acts Xxviii, I4.

130. Out of this construction there arose a usage of the greatest importance in Latin. The Acc. and Inf., instead of being regarded as two separate objects of the main verb, combined together so as to form a single object clause in which the Inf. acquired a predicative sense and the Acc. was regarded as its subject.

This usage is called the Acc. with the Inf. construction, because the Acc. gocs with the Inf. as its subject and not with the main verb as its object. 


\section{Dependent Statements}

Example:

Jussit eum duci in castra. He commanded him to be led to the camp.

Acts xxi, 34 .

This sentence does not state that the order was given to Paul: the whole clause duci eum in castra is the object of the main verb.

This construction is very common in $\mathrm{Cl}$. $\mathrm{L}$. in object clauses depending on verbs denoting saying or thinking (verba declarandi vel sentiendi).

Whole speeches are commonly reported in this way and are then given not in the words in which they were actually delivered, but in the words of a reporter. When applied to speeches this construction is called the Oratio Obliqua. It is very uncommon in the $\mathrm{Vg}$., for in the Heb. original of the O.T. speeches are given in the words of the original speaker and not reported. In the N.T. the influence of Heb. methods of expression causes the Oratio Obliqua to be equally rare and it is not common in Ecc. writers.

It seems unnecessary to go into a long description of this complicated construction in a book intended as an introduction to Ecc. L.

It may suffice to say that in this construction all main verbs are in the Inf. mood, and all verbs in subordinate clauses in the Subj. mood. The latter half of this rule is not universally observed in Ecc. $\mathrm{L}$.

131. Noun clauses standing as objects of verbs are of three kinds.

I. Dependent statements, or object clauses depending on verbs denoting saying or thinking (verba declarandi vel sentiendi).

2. Dependent commands, or object clauses depending on verbs denoting entreaty, command, exhortation, or bringing about (verba imperandi vel efficiendi).

3. Dependent questions, or object clauses depending on verbs meaning to ask a question, or clauses introduced by an interrogative word depending on verbs of various meanings.

132. Dependent statements. In Eng. these nearly always take the form of a clause introduced by that with the verb in the Ind. mood. The tense of the verb in these clauses is always one stage further in the past than the tense used by the original speaker, if the verb on which the clause depends is in a past tense. 
Thus:

He said that he was pleased to be in London.

The original words used by the speaker were:

I am pleased to be in London.

He said that he had seen his brother.

The original words used by the speaker were:

I have seen my brother.

He said that he would go to London on Friday.

The original words used by the speaker were:

$I$ will go to London on Friday.

N.B. In modern Grammars the tense formed with would and should is called the Future in the past.

This, as has been said, is the usual construction; but there are a few verbs in Eng. that are followed by an Acc. Inf. construction.

The judge declared him to be a criminal.

I believe them to be safe.

I consider you to be incompetent.

But even in the case of these verbs a clause introduced by that may also be used.

The judge declared that he was a criminal. (Notice the change of tense.)

I believe that they are safe.

I consider that you are incompetent.

133. In $\mathrm{Cl}$. L. the only construction that is used in object clauses after verbs of sentiendi vel declavandi is the Acc. and Inf.

As has already been explained a clause introduced by quod, quia or quoniam can be used in Ecc. L. instead of the Acc. and Inf. The verb in these clauses may be either Subj. or Ind.

If the main verb is in the third person singular or plural and the subject of the Inf. in the subordinate clause is the same as that of the main verb, the reflexive pronoun se is always used. Otherwise a demonstrative pronoun is used.

The use of the tenses of the Inf. is not very exact in Ecc. I., but, generally speaking, if the time of the action denoted by the main verb and that of the action denoted by the Inf. is the same, the Present Inf. is used.

Dicitis in Beelzebub ejicere me daemonia. You say that I cast out devils in Beelzebub.

Lk. xi, r8. 


\section{Dependent Statements}

If the time denoted by the Inf. is prior to that of the main verb the Perfect Inf. is used.

Aestimantes eum mortuum esse. Thinking he was dead.

Acts xiv, I9, xvi, 27; Phil. iii, I3.

If the time denoted by the Inf. is future to that of the main verb the Fut. Inf. is used.

Et responsum acceperat a Spiritu Sancto non visurum se mortem.... And he had received a reply from the Holy Ghost that he should not see death....

Lk. ij, 26.

134. The tenses of verbs in subordinate clauses in dependent statements should follow the rule of the sequence of tenses; but sometimes the tense used when the words were actually spoken or the thought framed is retained, in imitation of Gk.

Dicentes se visionem angelorum vidisse, qui dicunt eum vivere. Saying that they saw a vision of angels, who say that he is alive.

Lk. xxiv, 23.

Notice the use of se and enm in this example and also the use of an Ind. in a subordinate clause.

Huic omnes prophetae testimonium perhibent, remissionem peccatorum accipere per nomen ejus omnes qui credunt in eum. To him all the prophets bear witness that all who believe in him receive remission of sins through his name.

Acts $x, 43$.

The normal $\mathrm{Cl}$. construction is seen in the example below:

Et respondebant se nescire unde esset. And they answered that they did not know whence he was.

Lk. $\mathrm{xx}, 7$.

135. The following are examples of the construction of object clauses with quod, quia and quoniam, the origin of which is explained in sections I I 3 -I I 5 .

The verb may be in the Ind. or Subj. mood without any difference in meaning.

De escis autem quae idolis immolantur, scimus quia nihil est idolum in mundo, et quod nullus Deus nisi unus. With regard to meats offered to idols, we know that an idol is nothing in the world, and that there is no God but one. I Cor. viii, 4 .

Credere enim oportet accedentem ad Deum quia est, et inquirentibus se remunerator fit. For one that cometh to God ought to believe that he is, and that he becomes a rewarder of those that seek him.

Heb. xi, 6. 


\section{Quod used to introduce Direct Quotations}

Sometimes the tense of the original thought is retained as in Greek.

Et nesciebat quia verum est, quod fiebat per angelum. And he did not know that what was done by the angel was true.

Acts xii, 9.

The following is an example of the use of the quod, quia, quoniam construction from Tertullian, showing how soon this construction was adopted even by an educated writer:

Adeo postea in Actis Apostolorum invenimus, quoniam, qui Johannis baptismum habebant, non accepissent Spiritum Sanctum.

De Bapt. Io.

In the following examples the subject of the dependent clause is pleonastically repeated in the principal clause:

Dominus novit cogitationes sapientium quoniam vanae sunt. The Lord knoweth the thoughts of the wise that they are vain.

I Cor. iii, 20, cited from Ps. xciii, II.

Christus praedicatur quod resurrexit a mortuis. Christ is preached that he rose from the dead.

I Cor. Xv, I2.

See also Acts ix, 20.

In Acts xxi, 29 the object of the dependent clause is repeated in the main clause:

Viderant enim Trophimum Ephesium in civitate, quem aestimaverunt quoniam in templum introduxisset Paulus. For they had seen Trophimus an Ephesian in the city, whom they thought that Paul had brought into the temple.

136. Here may be noticed the very peculiar imitation of the Gk. idiom found in the N.T. and the LXX by which o'tı is used to introduce the actual words of a speaker. Quod, quia or quoniam are employed to translate ot $\tau$ in this sense quite indifferently. They must not be translated into Eng. The only Eng. equivalent to them when used in this way is the use of inverted commas. The punctuation of the $\mathrm{Vg}$. is sometimes peculiar, as will be seen from the examples below. The introductory word is printed with a capital letter after a colon, as if it were part of the speech.

Et mulieri dicebant: Quia jam non propter tuam loquellam credimus; ipsi enim audivimus, et scimus quia hic est vere salvator mundi. And they kept saying to the woman, "We believe, not because of your talking; for we have heard him ourselves, and we know that this is truly the saviour of the world." 


\section{Special Forms of Dependent Statements}

Scriptum est enim quod Angelis suis mandabit de te, ut conservent te: et quia In manibus tollent te... For it is written "He shall give his angels charge concerning thee, that they may preserve thee": and "In their hands they shail bear thee up...."

Lk. iv, IO, II.

Si quis dixerit quoniam diligo Deum, et fratrem suum oderit, mendax est. If any man say "I love God," and hateth his brother, he is a liar.

I Jn. iv, 20.

For the use of quod, quia, etc. see Jn. iv, $4^{6-54}$.

137. Special forms of dependent statements.

In $\mathrm{Cl}$. L. verbs denoting to promise, to hope, to swear, and similar verbs which relate to the future are followed by the Acc. with a Future Inf.

In Ecc. L. a Present Inf. may be used, or a clause introduced by quia, etc. or $u t$.

Devotione devovimus nos nihil gustaturos, donec occidamus Paulum. We have bound ourselves by a great curse that we will eat nothing until we have killed Paul.

Acts xxiii, I+.

Spero autem in Domino Jesu, Timotheum cito me mittere ad vos. But I hope in the Lord Jesus that I may send Timothy to you shortly.

Phil. ii, I 9.

Quibus autem juravit non introire in requien ipsius, nisi illis qui increduli fuerunt? But to whom did he swear that they should not enter into his rest, except to those that were unbelieving?

Heb. iii, I 8; Acts ii, 30 .

Simul et sperans quia pecunia daretur a Paulo. At the same time hoping that money would be given by Paul.

Acts xxiv, 26.

Juravit ut non transirem Jordanem. He swore that I should not pass over Jordan.

Deut. iv, 21 and i, 8 .

137a. In imitation of Heb. the verb jurare may be followed by si to express a strong negative, and by nisi to express a strong affirmative.

Sicut juravi in ira mea: Si introibunt in requiem meam. As I sware in my wrath: "They shall not enter into my rest." Heb. iii, I I.

Juravit per semetipsum, dicens: Nisi benedicens benedicam te, et multiplicans multiplicabo te. He sware by himself, saying: "Surely I will bless thee and muttiply thee exceedingly." Heb. vi, I3.

In Mk. viii, I 2 a construction of the same character is found after dicere.

Amen dico vobis, si dabitur generationi isti signum. Verily I say

to you, no sign shall be given to this generation.

The Hebraic form of adjuration Vivo ego, dicit Dominus is followed by quoniam or quia.

Vivo ego, dicit Dominus, quoniam mihi flectet omne genu.

Rom. xiv, I1, cited from Is, xly, 23. 


\section{Special Forms of Dependent Statements}

138. The verbs audive and videre may be followed by an Acc. and a participle in imitation of Gk., if they refer to something that was actually heard or seen when it was taking place.

Et vidit onnis populus eum ambulantem et laudantem Deum. And all the people saw him walking and praising God. Acts iii, 9 .

Et cadens in terram audit vocem dicentem sibi.... And falling to the earth he heard a voice saying to him... $\quad$ Acts ix, 4 . Contrast with this:

Audierunt autem de te quia discessionem doceas a Mose. For they have heard of thee that thou teachest departure from Moses.

See also Mt. vi, r6; Lk. iv, 23; Acts ii, 6.

Acts xxi, 2 r.

139. Verbs meaning to fear are followed in Cl. L. by a clause introduced by $n e$ (which is equivalent to lest or that in Eng.) when the subordinate clause is affirmative, and by a clause introduced by $u t$ when the subordinate clause is negative.

Vereor ne veniat. I fear that he will come.

Vereor ut veniat. I fear that he will not come.

Examples from the $\mathrm{Vg}$.:

Timens tribunus ne discerperetur Paulus ab ipsis.... The tribune fearing that Paul would be torn in pieces by them.... Acts xxiii, ro. In the Vg. an Inf. is found after timere:

Timuit illuc ire. He was afraid to go there.

Mt. ii, 22.

140. In $\mathrm{Cl}$. L. object clauses after verbs meaning to refuse, to prevent, etc. are introduced by quomimus or quin and have the verb in the Subj.

Quominus and quin are rare in the Vg. A Simple Inf. is found after verbs of this lind.

Non enim subterfugi quominus adnuntiarem... For I have not shrunk from announcing....

Acts $\mathrm{xx}, 27$.

Propter quod et impediebar...venire ad vos. On account of which $I$ was hindered from coming to you.

See also Acts xxiv, 24; 1 Cor. xiv, 39.

141. Mivari and admirari are followed by a clause introduced by quia or quod and occasionally by si in imitation of Gk.

Non mireris quia dixi tibi: Oportet vos nasci denuo. Wonder not that I said to you: Ye must be born again.

Jn. iii, 7 .

Nolite mirari, fratres, si odit vos mundus. Do not wonder, brethren, if the world hates you.

See also Mk. xv, 44 .

142. Dependent commands. In Eng. object clauses after verbs meaning to entreat, to command, to exhort, to bring about etc. are generally expressed by the Acc. and Inf. construction. 


\section{Dependent Commands}

In $\mathrm{Cl}$. L. they are nearly always expressed by a clause introduced by $u t$ with its verb in the Subj.

This causes a great deal of difficulty to beginners unless they get the fact clearly in their minds that where Cl. L. uses an Inf., Eng. generally uses a clause introduced by that, and where Cl. L. uses a clause introduced by $u t$ Eng. generally uses the Inf.

The verb jubeve, to command ${ }^{1}$, is followed by the Acc. Inf. construction in $\mathrm{Cl}$. L.

In Ecc. L. object clauses after verbs of commanding etc. are generally expressed by a clause introduced by $u t$. Sometimes $u t$ is omitted. An Acc. and Inf. construction may also be used after these verbs in imitation of Gk., or even a clause introduced by quod.

Rogate ergo Dominum messis ut ejiciat operarios in messem. Pray ye therefore the Lord of the havest to thrust out labourers into his harvest.

Mt. ix, 38 .

Statuerunt ut ascenderent Paulus et Barnabas. They determined that Paul and Barnabas should go up. Acts Xv, 2.

Ecce faciam illos ut veniant, et adorent ante pedes tuos. Behold I will make them come and worship before thy feet.

Rev. iii, 9 .

Notice the pleonastic repetition of the subject of the dep. clause as the object of the main clause.

Propter quod obsecro patienter me audias. Wherefore I beseech thee to hear me patiently.

See also Mt. viii, 4.

The following are examples of the use of the Inf.

Ascendens autem in unam navem, quae erat Simonis, rogavit eum a terra reducere pusillum. And going into one ship which was Simon's, he asked him to push out a little from the land.

Lk. v, 3 .

Petistis virum homicidam donari vobis. Ye asked for a murdever to be granted to you.

Acts iii, I4.

Admone illos principibus et potestatibus subditos esse. Warn them to be in subjection to princes and powers.

Tit. iii, I.

${ }^{1}$ N.B. Dicere often means to command in Ecc. L. It is then followed by a clause introduced by $u t$ or by an Inf.

Et dixit discipulis suis ut navicula sibi deserviret. And he commanded his disciples that a little ship should wait on him.

See also Mt. v, 39; Mk. v, 43; Rom. xii, 3 . Mk. iii, 9. 
Itaque, fratres, aemulamini prophetare. And so, brethren, desive earnestly to prophecy.

I Cor. xiv, I9.

Progenies viperarum, quis demonstravit vobis fugere a futura ira? Offspring of vipers, who warned you to flee from the wrath to come?

Mt. iii, 7 .

See also Acts iii, r2, xi, 24, xxvi, 29; I Cor. v, I r, vii, ro; Phil. iv, 2; Heb. xiii, I9; I Pet. ii, I 1.

The following is an example of a clause introduced by quod used as a dependent command.

Sed nos desideramus quod sicut voluntas Dei completa est in beatis, ita compleatur in nobis. But we pray that as the will of God is fulfilled among the blessed so it may be fulfilled among us.

Thomas Aquinas.

A clause introduced by si may be used after a verb denoting requesting, to denote a request that seems unlikely to be fulfilled.

Obsecrans si quomodo tandem aliquando prosperum iter habeam in voluntate Dei veniendi ad vos. Praying if by any means yet sometime I may have a prosperous joumey by the will of God to come to you.

Rom. i, Io.

143. Dependent questions. Object clauses after verbs meaning to ask a question or clauses introduced by an interrogative word after other verbs are called Dependent Questions in Latin grammar. In Eng. such clauses have the verb in the Ind. and present no difficulty; but in $\mathrm{Cl}$. L. the verb is always in the Subj. in these clauses.

In Ecc. L. the verb in a Dependent Question is often in the Ind. ${ }^{1}$ Examples of the ordinary Classical construction:

Et interrogabat quis esset, et quid fecisset. And he asked who he was, and what he had done.

Acts xxi, 33 .

Nescimus quid factum sit ei. We know not what has become of him.

Acts vii, 40 .

Et annuntiaverunt eis quanta ad eos principes sacerdotum et seniores dixissent. And they announced to them all that the chief priests and elders had said to them.

Acts iv, 23.

Et quaerebant summi sacerdotes et scribae quomodo eum cum dolo tenerent et occiderent. And the chief priests and

1 This usage is also found in early and late Latin. Compare Lucan, Pharsalia, i. $\mathrm{2} 26, \mathrm{ix}, 563$. 


\section{Noun Clauses in Apposition}

scribes sought how they might take him with guile and kill him.

Mk. xiv, I.

Cognoscet de doctrina utrum ex Deo sit, an ego a me ipso loquar. He shall know of the doctrine whether it is of God, or whether I speak of myself.

Jn. vii, I 7 .

144. Examples of dependent questions with the verb in the Ind.:

Domine, nescimus quo vadis. Lord, we know not whither thou goest.

Jn. xiv, 5 .

Redi domum tuam, et narra quanta tibi fecit Deus. Return to thy home, and tell all that God has done for thee. Lk. viii, 39.

Quomodo autem nunc videat, nescimus: aut quis ejus aperuit oculos nos nescimus. We know not how he now sees, nor do we know who opened his eyes.

Jn. ix, 2 I .

Indirect questions are sometimes introduced by si in Ecc. L. This is not $\mathrm{Cl}$.

Observabant eum scribae et Pharisaei, si Sabbato curaret. The scribes and Pharisees watched him if he would heal on the Sabbath.

Lk. vi, 7 .

Noun Clauses in apposition to a nOUN OR PRONOUN.

145. A noun clause is sometimes used in apposition to a noun or pronoun to explain the meaning of the noun or pronoun.

These clauses are generally expressed by $u t$ with the Subj. or by an Inf. In Ecc. L. they may be expressed by a clause introduced by quod, quia, quoniam.

Meus cibus est ut faciam voluntatem ejus, qui misit me. My meat is to do the will of him that sent me. Jn. iv, 34 .

Visum est Spiritui Sancto et nobis nihil ultra imponere vobis oneris quam haec necessario: ut abstineatis vos ab immolatis.... It seemed good to the Holy Spirit and to us to lay no further burden on you than these things necessarily: that you should abstain from things sacrificed....

Acts xv, 28.

Quandoquidem recte mihi vivere puero id proponebatur, obtemperare monentibus. Since this was set before me as the ideal of a boy's existence, namely to obey those that instructed me.

See also Jn. vi, 39, 40, xvi, 32 .

Augustine.

Hoc est autem judicium: quia lux venit in mundum, et dilexerunt homines magis tenebras quam lucem.... But this 
is the judgement: that light came into the world, and men loved darkness rather than light.

Jn. iii, I9.

Omnia ostendi vobis, quoniam sic laborantes oportet suscipere infirmos. I have shown you all things, that so labouring ye. ought to support the weak.

Acts $\mathrm{xx}, 35$.

See also Phil. i, 6.

146. The Infinitive used as an Imperative. The Pres. Inf. is very rarely used in the sense of an Imperative in imitation of a rare use in N.T. Gk. This idiom is found in French and Italian, rarely in Eng.

Gaudere cum gaudentibus, flere cum flentibus. Rejoice with them that do rejoice and weep with those that weep.

The Inf. in Mt. v, 34, 39 may possibly be an Imperative Inf.

147. Explanatory Infinitive. The Inf. (retaining somewhat of its original Dat. sense) is used with certain adjectives and nouns, generally such as denote power, capacity, merit, fitness, in an explanatory sense.

Scio cui credidi, et certus sum quia potens est depositum meum servare in illum diem. I know in whom I have believed and $I$ am certain that he is able to keep that which I have deposited with him wntil that day.

II Tim. i, I2.

See also Lk. v, 24; II Cor. ix, 8; Rev. xiii, 5.

Qui idonei erunt et alios docere. Who shall be fit to teach others also.

II Tim. ii, 2.

Non habent necesse ire. They have no need to go away.

But we also find:

Mt. xiv, I6.

Et non necesse habetis ut aliquis doceat vos. And ye have no need that anyone should teach you.

I Jn. ii, 27.

Et jam non sum dignus vocari filius tuus. And $I$ am no longer worthy to be called thy son.

Lk. xv, I9, xxi, 36 .

A clause introduced by $u t$ is also used with dignus in imitation of the Gk. Jn. i, 27 .

See also Mt. viii, 8.

Et hoc scientes tempus: quia lora est jam nos de somno surgere. And that knowing the time, that it is now the hour for us to awake out of sleep.

Rom. xiii, I I ; Rev. xi, I8.

Bonam voluntatem habemus magis peregrinari a corpore, et praesentes esse ad Dominum. We have a good will rather to be absent from the body and to be present with the Lord.

II Cor. v, 8. 


\section{Adjectival Clauses}

In Cl. L. prose such words would be followed by a Gerund or Gerundive with ad, by a Relative clause, or by a Gen. of the Gerund or Gerundive, as in this example:

Et hic habet potestatem a principibus sacerdotum alligandi omnes, qui invocant nomen tuum. And here he has power from the chief priests to bind all that call on thy name.

Acts ix, I4.

148. The Inf. is used in an explanatory sense after verbs: sometimes it describes the purpose and sometimes the consequence of the verb on which it depends.

It is used in imitation of Gk., and would not be so used in $\mathrm{Cl}$. prose.

Esurivi enim et dedistis me manducare. I was hungry and ye gave me to eat.

Mt. $x x v, 35$.

Quomodo tu, Judaeus cum sis, bibere a me poscis, quae sum mulier Samaritana? How is it that thou, although thou art a Jew, askest to drink of we who am a Samaritan woman?

Jn. iv, 9 .

Observabant autem scribae et Pharisaei si sabbato curaret, ut invenirent accusare illum. And the scribes and the Pharisees watched him, whether he would heal on the Sabbath; that they might find how to accuse him.

Lk. vi, 7 .

Moram facit Dominus meus venire. My lord delays to come.

II. xxiv, 49 .

Elegit Deus per os meum audire gentes verbum evangelii. God chose that the Gentiles should hear through my mouth the word of the gospel.

Acts $x v, 7$.

Nunc ergo quid temptatis Deum imponere jugum super cervicem discipulorum? Now thevefore why do ye tempt God to put a yoke upon the neck of the disciples?

See also Mt. vii, 5; Acts xvi, I 4 ; Heb. xi, 8.

The Vg. is not at all consistent in this usage. Ut is used in Heb. v, 5, vi, 10, and Col. iv, 6, where an Inf. is used in Gk.

\section{ADJECTIVAL CLAUSES.}

149. An Adjectival Clause qualifies a noun or pronoun, which is called its antecedent, in the same way as an adjective.

Adjectival clauses are introduced by the relative pronouns qui, quicumque, or by the relative adverbs quo, unde, quomodo, etc.

When an adjectival or relative clause, as it is generally called, 
refers to an actual event or fact, it is called a Definite Relative Clause.

When a relative clause refers to a supposed event or instance and hence implies a condition, it is called an Indefinite Relative Clause.

The verb in a definite relative clause is in the Ind. mood, as it is in Eng.; unless the clause comes under one of the classes specified below which have their verb in the Subj.

Example:

Nonne ecce omnes isti qui loquuntur Galilaei sunt? Are not all these who speak Galilaeans? Acts ii, 7 .

150. The verb in a definite relative clause is in the Subj. mood.

(I) To indicate that the person or thing denoted by the antecedent is capable of performing, or is of such a character as to be likely to perform or to suffer the action denoted by the relative clause.

Such clauses may be called Characterising Relative Clauses.

Viri Ephesii, quis enim est hominum, qui nesciat Ephesiorum civitatem cultricem esse magnae Dianae? Men of Ephesus, what man is there that does not know that the city of the Ephesians is a worshipper of great Diana?

Acts xix, 35 .

Quia adversarius vester diabolus tamquam leo rugiens circuit, quaerens quem devoret. Because your adversary the devil goeth about like a roaring lion seeking whom he may devour.

I Pet. v, 8.

Neminem enim habeo tam unanimem, qui sincera affectione pro vobis sollicitus sit. For I have no one so like minded who with sincere affection is likely to cave for you.

Phil. ii, 20.

Filius autem hominis non habet ubi caput reclinet. For the Son of man hath not where to lay his head.

Mt. viii, 20.

See also Acts xi, I7, xiii, I I; Jn. xii, 48; I Kings xviii, 26.

The following uses are alin to the above:

(a) A Subj. is sometimes found in a relative clause when the principal clause has for its predication the idea of existence.

Ego autem non quaero gloriam meam: est qui quaerat et judicet. ${ }^{1}$. But I do not seek my own glory: there is one that seeks and judges.

Jn. viii, 50 .

Onmes declinaverunt, simul inutiles facti sunt, non est qui faciat bonum, non est usque ad unum. They have all gone out

1 This is the reading of SC. WIV has Ind. in both verbs. 


\section{Subjunctive in Adjectival Clauses}

of the way, they have all together become profitless, there is not one that doeth good, no not one.

Rom. iii, I2.

(b) A relative clause with the verb in the Subj. is sometimes found after the adjectives dignus and indigmus.

Et si in vobis judicabitur mundus, indigni estis, qui de minimis judicetis? And if the world shall be judged by you, are you mworthy to judge the smallest matters?

I Cor, vi, 2.

(2) The Subj. is used in a relative clause if the clause expresses purpose, consequence, or cause.

Purpose:

Et observantes miserunt insidiatores, qui se justos simularent. And observing him they sent forth spies who should feign themselves to be just men.

Lk. $\mathrm{xx}, 2 \mathrm{o}$. Consequence:

Quis enim novit sensum Domini, qui instruat eum? For who knows the mind of the Lord, so as to instruct him? I Cor. ii, I6.

Nam et Pater tales quaerit, qui adorent eum. For the Father looks for such to worship him.

Jn. iv, 23 .

(3) When a relative clause forms part of a sentence in an indirect statement or question, and generally when it depends on a clause with its verb in the Subj., the verb in the relative clause is put in the Subj. in Cl. L.

This rule is not generally observed in the $\mathrm{Vg}$.

Et dum intra se haesitaret Petrus quidnam esset visio quam vidisset.... And while Peter doubted in himself what the vision was which he had seen....

Acts $x, 17$.

In Mt. xxvii, I 5 there is an example of a relative clause of this kind. It expresses the wish of the people not directly, but indirectly. This construction is called Virtual Oratio Obliqua.

The following is an example of the Ind. used in a relative clause of this kind:

Venerunt dicentes se etiam visionem angelorum vidisse, qui dicunt eum vivere. They came saying that they had also seen a vision of angels who say that ine is alive.

In $\mathrm{Cl}$. L. this would be: quid dicerent enm vivere.

(4) In Ecc. L. the Subj. is used in relative clauses withont any apparent reason.

Nec enim nomen aliud est sub caelo datum hominibus, in quo oporteat nos salvos fieri. For there is no other name under heaven given to men whereby we must be saved.

Acts iv, 12. 
151. The Future Perfect tense is generally used in indefinite relative clauses referring to future time.

Non occides: qui autem occiderit reus erit judicio. Thon shalt not kill: but whosoever shall kill shall be guilty so as to be in danger of the judgement.

Mt. $v, 2$.

\section{ADVERBIAL CLAUSES.}

152. Adverbial Clauses are clauses that stand in relationship of an adverb to some verb in another clause.

Adverbial clauses may be divided into eight classes.

(I) Clauses of Time.

(2) Clauses of Place.

(Temporal Clauses.)

(3) Clauses of Cause.

(Local Clauses.)

(4) Clanses of Purpose.

(Causal Clauses.)

(5) Clauses of Consequence.

(Final Clauses.)

(6) Clauses of Concession.

(Consecutive Clauses.)

(7) Clauses of Condition.

(Concessive Clauses.)

(8) Clauses of Comparison.

(Conditional Clauses.)

(Comparative Clauses.)

The names given in brackets are those given to these clauses in most grammars. They are not very satisfactory, as the words temporal, funal, consecutive have quite a different sense in ordinary use to that which they have when used as grammatical terms. These names should however be known, as they are so commonly used.

The names given first are those suggested by the Committee on Grammatical Terminology.

153. (I) Clauses of Time denote the time of the action of the verb in the clanse on which they depend.

They are introduced by the conjunctions

$$
\begin{aligned}
& \text { cum, ut }{ }^{1} \text {, quando, } \mathrm{ubi}^{2}=\text { when; } \\
& \text { antequam, priusquam = before; } \\
& \text { postquam = after; } \\
& \text { dum = while, until; } \\
& \text { donec, quando } \quad=\text { until. }
\end{aligned}
$$

1 This use of $u t$ must be carefully distinguished from the uses mentioned in sections $157,158,163$.

" wbi nearly always means where in the Vg., but see Gal. iv, 4 . 


\section{Clauses of Time}

The Ind. mood is used in clauses of time introduced by $u t$, quando, ubi and postquam. (In Ecc. L. the Subj. is rarely found after postquam. Lk. xv, I4; Rev. xxii, 8.)

Venit nox, quando nemo potest operari. The night cometh, when no man can work.

Jn. ix, 4 .

Et ut cognovit vocem Petri, prae gaudio non aperuit januam. And when she knew the voice of Peter, she did not open the door for joy.

Acts xii, I 4 .

Postquam autem resurrexero, praecedam vos in Galilaeam. But after I am risen, I will go before you into Galilee.

Mt. xxvi, 32 .

153a. A clause introduced by cum has the verb in the Ind., if the clause only indicates the time of the action of the verb which it qualifies. If the clause introduced by cum denotes the circumstances that lead up to the condition or action of the verb which it qualifies, the verb in the clause introduced by cum is in the Subj. mood.

In Ecc. L. the verb in a clause introd. by cum is sometimes put in the Subj. mood without any apparent reason.

In the following examples the clause introduced by cum only indicates the time of the action of the verb which it qualifies.

In the first three the verb is in the Ind. mood in accordance with Cl. usage: in the fourth the Subj. is used.

In veritate dico vobis, multae viduae erant in diebus Heliae in Israel, quando clausum est caelum annis tribus et mensibus sex, cum facta est fames magna in omni terra. I tell you in truth there were many widows in the days of Elias in Israel, when the heaven was shut up for three years and six months, when c great famine took place in all the earth. Lk. iv, 25.

Et spiritus immundi, cum eum videbant, procidebant ei. And the unclean spivits, when they saw him, used to fall down before him.

Mk. iii, I I.

Cum ergo venerit, ille nobis annuntiabit omnia. Whenever therefore he shall come, he will tell us all things.

Jn. iv, 25 .

Cum autem adpropinquaret portae civitatis, et ecce defunctus efferebatur. But when he was drawing near to the gate of the city, behold a dead man was being borne out. Lk. vii, I2.

In the following examples the clause introduced by cum denotes not only the time of the action of the main verb, but also 
the attendant circumstances which explain it, or seem likely to hinder it.

Quod cum videret Simon Petrus, procidit ad genua Jesu. And when Simon Peter saw it, he fell down at Jesus' knees.

Lk. v, 8.

(The clause explains why he fell down.)

Quomodo potest homo nasci cum senex sit? How can a man be born when he is old?

(His age is likely to prevent his being born.)

$\mathrm{Ne}$ forte, cum aliis praedicaverim, ipse reprobus efficiar. Lest perchance, when I have preached to others, I myself may become reprobate.

I Cor. ix, 27.

(The fact that he has preached to others ought to save him from becoming reprobate; but will it?)

154. In clauses introduced by antequam, priusquam, dum, donec, quoad, either the Ind. or the Subj. mood may be used.

The Ind. mood is used in Cl. L. if the clause merely denotes the time of the action of the verb which it qualifies.

The Subj. mood is used if the clause refers to an action which is only in prospect and explains the purpose of the action of the verb which it qualifies.

Examples:

Clause simply denoting time.

Antequam abiit, hoc dixit. He said this before he went away.

Dum mecum eras, ille in Hispaniam properavit. While you were with me, he hastened into Spain.

Clause denoting expectation and purpose.

Num expectas donec testimonium dicat? Are you waiting until he gives his evidence? (i.e. with a view to heaving him).

Impetum hostium sustinuit donec ceteri scalas ad muros ponerent. He sustained the attack of the enemy until the others could set ladders to the walls.

Ad oppidum, antequam milites a terrore se reciperent, properavit. He hastened to the town (so as to be there) before the soldiers should recover themselves from their terror.

In Ecc. L. either the Ind. or the Subj. is used in clauses introduced by antequam, priusquam, dum, donec, without any distinction of meaning. The Subj. is more frequently used than the Ind. 
Examples from the Vg.:

Priusquam te Philippus vocaret, cum esses sub ficu, vidi te. Before Philip called thee, when thou wast under the fig tree, I saw thee. Jn. i, $4^{8 .}$

Duim autem irent emere, venit sponsus. But while they went to buy, the bridegroom came.

Mli. xxv, Io.

Simile est regnum caelorum fermento, quod acceptum mulier abscondit in farinae satis tribus, donec fermentatum est totum. The kingdom of heaven is like leaven which a woman took and hid in three measures of meal, until the whole was leavened.

Mt. xiii, 33 .

Dico tibi, Petre, non cantabit hodie gallus, donec ter abneges nosse me. I say to thee, Peter, the cock shall not crow this day until thou hast denied three times that thou knowest me.

Lk. xxii, 34.

See also Mt. xviii, 3o; Lk. viii, 42, ix, 27, 29; Acts xxi, 26, 27.

Clauses of time may also be expressed by the Abl. Absolute or by a Participle: see sections $5 \mathrm{I}, \mathrm{I} 83$.

155. (2) Clauses of Place denote the place where the action of the verb in the clause on which they depend is said to happen.

They are introduced by the conjunctions

$$
\begin{aligned}
& \text { ubi, quo }=\text { where, whither; } \\
& \text { unde }=\text { whence. }
\end{aligned}
$$

Mood: Ind., as in Eng.

If the clause of place refers to an action which will take place in some indefinite place in future time, the verb is generally in the Future Perfect tense.

Nolite thesaurizare vobis thesauros in terra, ubi erugo et tinea demolitur. Lay not up for yourselves treasures on the earth, where rust and moth do cormpt.

Mt. vi, I9.

Ego semper docui in synagoga et in templo, cuo omnes Judaei conveniunt.... I always taught in the synagogue and in the temple, whither all the Jews come together....

Jn. xviii, 20.

Amen dico vobis, ubicumque praedicatum fuerit hoc evangelium in toto mundo, dicetur et quod haec fecit in memoriam ejus. Verily I say to you, wherever this gospel shall be preached 


\section{Clauses of Cause}

in the whole world, this which she hath done shall be told for a memorial of her.

Mt. xxvi, I3.

156. (3) Clauses of Cause denote the reason (real or alleged) given for the action of the verb in the clause on which they depend.

They are introduced by quia, quoniam, quod, eo quod, cum, = since, because, etc.

In Cl. L. the Ind. is generally used in clauses introduced by quia, quoniam, quod, if the clause states what was the real cause of the action of the main verb in the opinion of the speaker or writer.

If however the clause denotes the cause of the action of the main verb in the opinion of some one other than the speaker or writer, or gives an opinion as to its cause which the speaker or writer once held, but which he now does not hold, the Subj. is used.

Examples:

Judaei Apostolos, quod legem violaverant, persecuti sunt. The Jews persecuted the Apostles because they had (in point of fact) broken the law.

Judaei Apostolos, quod legem violavissent, persecuti sunt. The Jews persecrited the Apostles, because (in the opinion of the Jews) they had broken the law.

In the first example the writer states that the Apostles were persecuted because they had actually broken the law. In the second example the writer leaves it an open question as to whether the Apostles had broken the law, or not; but he states that the Jews persecuted them, because they thought the Apostles had broken the law.

In Ecc. L. clauses introduced by quia, quoniam, quod, eo quod may have the verb in the Subj. even when they imply that the cause given for the action of the main verb is the real cause in the opinion of the speaker or writer.

Exi a me, quia homo peccator sum, Domine. Depart from me, for I am a sinful man, O Lord. Lk. v, 8 .

Serve nequam, omne debitum dimisi tibi, quoniam rogasti me. Thou worthless slave, I forgave thee all thy debt because thou didst ask me.

Mt. xviii, 32 .

Non quod ipse esset Pater et Filius... sed quod tam similes sint Pater et Filius, ut qui unum noverit, ambos noverit. Not because the Father and the Son were the same. . but because 


\section{Clauses of Purpose}

the Father and the Son are so much alike, that he who knows one, knows both.

Aug. Tract. in Joh. lxx.

Ipse autem Jesus non credebat semetipsum eis, eo quod ipse nosset omnes. But Jesus himself did not trust himself to them, because he knew all men.

Jn. ii, 24 .

N.B. These clauses should be carefully distinguished from the noun clauses introduced by quia, quoniam and quod dealt with in sections I 2 sq.

156a. Clauses of cause introduced by cum have the verb in the Subj. both in Cl. and Ecc. L.

De omnibus quibus accusor a Judaeis, rex Agrippa, aestimo me beatum apud te cum sim defensurus me hodie. I think that I ain fortunate, king Agrippa, because I am going to defend myself before thee about all the things whereof I am accused by the Jews.

Acts xxvi, 2.

Hi homines conturbant civitatem nostram, cum sint Judaei. These men disturb our state, because they are Jews.

Acts xvi, 20.

Rarely an Ind. is found in these clauses:

Ut, cum circa servos talis est Dominus, exemplo suo doceret, qualis circa compares et aequales debeat esse conservus. That he might teach by his example what a fellow-servant ought to be with respect to his companions and equals, since he himself is such a Lord to his servants.

Cypr. De bono patientiae.

Clauses of cause may also be expressed by a Participle or by the Abl. Absolute. See sections 5I, I83.

157. (4) Clauses of Purpose denote the purpose of the action of the verb in the clause on which they depend.

Clauses of purpose are generally introduced by

"t when affirmative $=$ that, in order that,

ne when negative (ut non in Ecc. L.),

quo when comparative.

Mood: Subj. always.

These clauses may also be expressed by

I. A relative clause with the verb in the Subj.

2. The Gerund or Gerundive Participle with ad or causa.

3. A Future Participle. (In Ecc. L. a Present Participle may be used in this sense.)

4. A Supine. (This is rare.) 
157a. In Ecc. L. an Inf. is often used to express purpose as in Eng. and Gk.

This construction is found in the Latin poets, but not in $\mathrm{Cl}$. prose. It seems to have been a vernacular idiom which came into literary use at a late period.

158. Purpose expressed by $u t$, etc.

Paenitemini igitur et convertimini, ut deleantur vestra peccata. Repent therefore and be converted that your sins may be blotted out.

Acts iii, I9.

Hic venit in testimonium, ut testimonium perhiberet de lumine. He came for a testimony in order that he might bear witness about the light.

Jn. i, 7 .

Et in manibus tollent te, ne forte offendas ad lapidem. And they shall bear thee in their hands, that thou dash not thy foot against a stone.

Mt. iv, 6.

Nolite judicare ut non judicemini. Judge not that ye be not judged.

Mt. vii, I.

159. Purpose expressed by a relative clause.

Considerate ergo, fratres, viros ex vobis boni testimonii septem, ... quos constituamus super hoc opus. Look ont therefore from among yourselves, brethren, seven men of good report that we may set them over this work.

Acts vi, 3.

Tunc summiserunt viros, qui dicerent se audisse eum dicentem verba blasphemiae in Mosen et Deum. Then they' suborned men to say that they had heard him speaking blasphemous words against Moses and God.

Acts vi, I I.

160. Purpose expressed by the Gerundive Participle with ad.

Propterea et ego amplius non sustinens, misi ad cognoscendam fidem vestram. Wherefore $I$ also, since I could no longer forbear, sent to know your faith.

I Thess. iii, 5 .

See also Rom. xv, 8.

161. Purpose expressed by the Future or the Present Participle.

Post annos autem plures eleemosynas facturus in gentem meam veni. But after many years I came to give alms to my nation.

Acts xxiv, I7.

Vobis primum Deus suscitans Filium suum, misit eum bene- 


\section{Clauses of Consequence}

dicentem vobis. For you first God, having raised up his Son, sent Him to bless you.

See also Jn. vi, 6.

Acts iii, 26.

162. Purpose expressed by the Inf.

Venisti huc ante tempus torquere nos? Hast thou come here before the time to torment us?

IIt. viii, 29.

Et circumspiciebat videre eam quae hoc fecerat. And he looked about to see her that had done this.

IIk. $v, 32$.

Non enim misit me Christus baptizare, sed evangelizare. For Christ sent me not to baptize, but to preach the gospel.

I Cor. i, I 7 .

163. (5) Clauses of Consequence denote the consequence or result of the action of the verb in the clause on which they depend.

They are introduced by ut or ita ut, so that, when affirmative and are negatived by non.

Mood: Subj. always.

Sic enim dilexit Deus mundum, ut Filium suum unigenitum daret. For God so loved the world, that he gave his only begotten Son.

Jn. iii, I6.

Et convenerunt multi, ita ut non caperet neque ad januam. And many came together, so that there was no room for them even at the door.

IIk. ii, 2.

Numquid aquam quis prohibere potest, ut non baptizentur hi qui Spiritum Sanctum acceperunt sicut et nos? Can any forbid water, that these should be baptized who have received the Holy Ghost as well as we?

Acts $x, 47$.

Si confiteamur peccata nostra fidelis est et justus ut remittat nobis peccata nostra. If we confess our sins, he is faithful and just to forgive us our sins.

I Jn. i, 9 .

These clauses should be observed with special care as the construction of them is so very unlike Eng.

164. The Inf. may be used (in the Vg.) to denote consequence in imitation of the Gk.

O insensati Galatae quis vos fascinavit non obedire veritati? O foolish Galatians, who has bewitched you that you should not ${ }^{1}$ obey the truth?

Gal. iii, I.

Et quomodo conversi estis ad Deum a simulacris, servire 1 This is reading of SC text. 
Deo vivo et vero. And how ye were tumed to God from idols, to serve the living and true God.

I Thess. i, 9.

Anania, cur temtavit Satanas cor tuum, mentiri te Spiritui Sancto? Ananias, why hath Satan tempted thine heart that thou shouldest lie to the Holy Spirit?

Acts $v, 3$.

In Ronı. i, to a Gk. Inf. denoting consequence is trans. by the Genl. of the Gerund.

165. Very rarely clauses of consequence are introduced by quia, and once, in a quotation from the O.T., by quod and quoniam.

Quo hic iturus est, quia non inveniemus eum? Where does he intend to go that we shall not find him?

See also Mt. viii, 27; Mlk. iv, 40.

Quid est homo quod memor es ejus, aut filius hominis quoniam visitas eum? What is man that thou art mindful of him, or the son of man that thou visitest him? Heb. ii, 6, cited from Ps. viii, 5.

166. (6) Clauses of Concession denote some fact which is regarded as likely to prevent or to have prevented the occurrence of the action of the verb in the clause on which they depend.

They are introduced by cum, quamvis, etsi, licet $=$ although. In the Vg. the principal clause may be introduced by sed or sed tamen: see examples below.

In clauses introduced by $\mathrm{cum}$ in this sense, the verb is always in the Subj. In Cl. L. quamquam is followed by a verb in the Ind. and quamvis is followed by a verb in the Subj. In Ecc. L. the Subj. is found after both these words. Clauses introduced by etsi are similar in construction to clauses of condition. Clauses introduced by licet have the verb in the Subj. (Ind. in Vg.).

The tense is the same as that which is used in the English. Negative non.

Ecce et naves, cum magnae sint, et a ventis validis minentur, circunferuntur a modico gubernaculo. Behold also the ships, although they are so big and although they are threatened by strong winds, are turned about by a small helm. Jas. iii, 4 .

See also Mit. xxvi, 60 .

Unum scio, quia caecus cum essem, modo video. One thing I know, that, although I was blind, now I see. Jn. ix, 25.

Nam cum liber essem ex omnibus, omnium me servum feci. For although I was free from all men, I made myself a slave of all. I Cor. ix, r9. 


\section{Clauses of Condition}

Quamvis non longe sit ab unoquoque nostrum. Although lie is not far from each one of uts.

Acts xvii, 27.

Quamquam Jesus non baptizaret, sed discipuli ejus. Although Jesus did not baptize, but his disciples.

See also Phil. iii, 4; Heb. vii, 5.

Cum possemus vobis oneri esse... sed facti sumus parvuli in medio vestrum. Although we might have been burdensome to you... we made ourselves like little children in the midst of you.

I Thess. ii, 7 .

Etsi omnes scandalizati fuerint: sed non ego. Although all shall be offended in thee: yet will I never be offended.

See also Col. ii, 5 .

Mk. xiv, 29.

Sed licet nos, aut angelus de caelo evangelizet vobis praeterquam quod evangelizavimus vobis, anathema sit. But although we, or an angel from heaven preach to you any other gospel than that which we have preached to you, let him be accursed.

Gal. i, 8.

Sed licet is qui foris est noster homo corrumpitur.... But although our outward man decay's... $\quad$ II Cor. iv, I6.

A clause of concession may also be expressed by a participle or by the Abl. Absolute. See sections 5I, I83.

167. (7) Clauses of Condition state the condition on which the action of the verb in the clause on which they depend would take place.

A clause of condition and the clause on which it depends make up a sentence which is called a Conditional Sentence. In such a sentence the clause of condition states a supposition, and the principal clause states the result of the fulfilment of the supposition.

The clause of condition is called the Protasis and the principal clause is calied the Apodosis of the conditional sentence.

Clauses of condition are introduced by si, if, nisi, unless. Negative non.

In $\mathrm{Cl}$. L. if the verb in the principal clause is in the Ind. mood, the verb in the clause of condition is also in the Ind. mood. If the verb in the principal clause is in the Subj. mood, the verb in the clause of condition is also in the Subj. mood. There are exceptions to this rule; but they are rare and generally due to a desire to produce a rhetorical effect. In Ecc. L. the rule given above is not strictly observed. 
The construction of conditional sentences varies according as the time of the supposition is Past, Present, or Future, and according as the condition is regarded as fulfilled, or unfulfilled.

It is obvious that a condition is never regarded as fulfilled at the time contemplated by the clause on which it depends. It may however be stated in such a way as to imply that it has not been fulfilled.

\section{Consider the sentences}

If you are ill I shall send for the doctor.

If you were ill I should send for the doctor.

If you had been ill I should have sent for the doctor.

In the first of these sentences it is left an open question whether the condition has been fulfilled, or not. In the other two sentences it is implied that the condition has not been fulfilled. The first of the two relates to illness extending up to the present time: the second of the two refers to illness in the past.

The two latter sentences illustrate what is meant by an unfulfilled conditional sentence.

168. Present or past suppositions implying nothing as to the fulfilment of the condition.

A Present or Past tense of the Ind. is used in the clause of condition. Almostany part of the verb may be used in the principal clause.

Si judico ego, judicium meum verum est. If I judge, my judgment is true.

Jn. viii, I6.

Si Filius Dei es, dic ut lapides isti panes fiant. If thou art the Son of God, command these stones to become loaves....

Mt. iv, 3 .

Si Abraham ex operibus justificatus est, habet gloriam. If Abraham was justified by works, he has where of to glory.

Rom. iv, 2.

Si vero ex Deo est, non poteritis dissolvere eos. If it is really of God, you will not be able to break them up. Acts v, 39 .

169. Present or Past suppositions implying that the condition has not been fulfilled.

The Imperfect or Pluperfect Subj. is used both in the clause of condition and in the principal clause. The Imperfect Subj. denotes continued action in past time, or action extending up to the 


\section{Unfulfilled Clauses of Condition}

present moment. The Pluperfect Subj. denotes action in past time.

Si adhuc hominibus placerem, Christi servus non essem. If I were still pleasing men, I should not be the slave of Christ. Gal. i, Io.

Si diligeretis me, gauderetis utique. If ye loved me, ye would certainly rejoice.

Jn. xiv, 28 .

Non haberes potestatem adversum me ullam, nisi tibi datum esset de super. Thou wouldst have no power at all against me unless it had been given thee from above.

Jn. xix, I I .

Si non esset hic malefactor, non tibi tradidissemus eum. If this man were not a malefactor, we would not have given him up to thee.

Jn. xviii, 30 .

Si opera non fecissem in eis, quae nemo alius fecit, peccatum non haberent. If I had not done among them the works that no man else did, they would not have sin.

Jn. $\mathrm{xv}, 24$.

Domine, si fuisses hic, frater meus non fuisset mortuus. Lord, if thou hadst been here, my brother would not have died.

$$
\text { Jn. xi, } 2 \text { I. }
$$

170. If one of the Modal verbs such as possum, debeo, oportet or a Periphrastic tense made up of the Future Participle or the Gerund or Gerundive with part of esse stands in the principal clause of a conditional sentence in which there is a Subj. in the clause of condition, the Indicative mood of such verbs is used instead of the Subj.

Nisi esset hic a Deo, non poterat facere quicquam. If this man were not of God, he could do nothing.

Jn. ix, 33.

Dimitti poterat homo hic, si non appellasset Caesarem. This man might be let go, if he had not appealed to Caesar.

Acts xxvi, 32.

171. The following are examples of sentences in which the rule that, if there is an Ind. in the principal clause, there should be an Ind. in the clause of condition is not observed.

Bonum erat ei, si natus non fuisset homo ille. It was good for that man, if he had not been born.

Mt. xxvi, 24.

Nam concupiscentiam nesciebam, nisi lex diceret: Non concupisces. For $I$ did not know covetousness, if the law had not said: Thou shalt not covet.

Rom. vii, 7 . 
172. Future Suppositions. There are two forms of future suppositions.

I. The more vivid form.

2. The less vivid form.

The Future or Future Perfect Indicative is used in the more vivid form. The Present Subj. is used in the less vivid form.

In Eng. the Present Ind. is often used in the Protasis of these conditional sentences. This use is really incorrect: the Latin is much more accurate in its use of tenses: consider the force of the Latin Future and Future Perfect tenses in the examples given below.

If the action expressed in the Protasis of the conditional sentence is represented as taking place before the action denoted by the verb in the principal clause, the Future Perfect is properly used, because the action denoted by the principal clause is itself still future. Strictly speaking the Future should only be used in the Protasis when the time denoted by the Protasis and Apodosis is identical. For example:

Dum hic ero, te amabo. As long as I am heve, I shall love you.

It will be noticed however that this principle is not strictly observed.

Si quis autem templum Dei violaverit, disperdet eum Deus. But if any man defile the temple of God, him will God destroy.

I Cor. iii, I7.

Si omnes scandalizati fuerint in te, ego numquam scandalizabor. If all men shall be offended in thee, yet will I never be offended.

Mt. xxvi, 33 .

Haec tibi omnia dabo, si cadens adoraveris me. All these things will I give thee, if thou wilt fall down and worship me.

Mt. iv, 9.

Fidelis sermo: nam si commortui sumus, et convivemus: si sustinebimus, et conregnabimus : si negabimus, et ille negabit nos. Faithful is the saying: for if we have died with him, we shall also live with him: if we endure, we shall also reign with him: if we deny him, he also will deny us.

II Tim. ii, II.

173. The use of the less vivid form is rare.

Quid enim proficit homo, si lucretur mniversum mundum, se autem ipsum perdat, et detrimentum sui faciat? For what 


\section{Clauses of Comparison}

does it profit a man if he should gain the whole world, but lose himself, and work his own destruction?

Lk. ix, 25.

Sic est regnum Dei, quemadmodum si homo jaciat sementem in terram.... So is the kingdom of God as if a man should cast a seed into the earth....

MIk. iv, 26.

See also I Cor. vii, 8.

174. In accordance with Heb. usage, sentences similar in meaning to Conditional Sentences are found in the $\mathrm{Vg}$. where the conditional clause is expressed by (a) an inversion, (b) an Imperative.

(a) Tristatur aliquis vestrum? oret aequo animo et psallat. Infirmatur quis in vobis? inducat presbyteros Ecclesiae. Is any sad among you? let him pray with a calm mind and let him sing psalms. Is any sick among you? let him send for the elders of the Church.

Jas. v, I 3 .

(b) Petite, et dabitur vobis: quaerite, et invenietis: pulsate, et aperietur vobis. Ask, and it shall be given to yout: seek, and ye shall find: knock, and it shall be opened to yout.

Nit. vii, 7 .

175. (8) Clauses of Comparison compare the action or state denoted by the verb in the clause on which they depend to the action or state denoted in the clause of comparison.

They are introduced by $u t$, sicut, prout, quomodo, tanquam, quasi, etc., as, as if. Negative non.

The verb in clauses of comparison is in the Indicative, if it is implied that the comparison is real.

If it is implied that the comparison is not real, the verb may be in the Subjunctive.

Sometimes only a Participle is used and sometimes the verb is omitted altogether in the clause of comparison.

Ita et viri debent diligere uxores ut corpora sua. So men ought to love their wives as their own bodies. Eph. v, 28.

Non ergo oportuit et te misereri conservi tui, sicut et ego tui misertus sum? Oughtest thou not therefore to have had pity on thy fellow slave, even as I had pity on thee? Mt. xviii, 33 .

Ut quomodo Christus surrexit a mortuis...ita et nos in novitate vitae ambulemus. That as Christ rose from the dead ...so we also may walk in newness of life. Rom. vi, 4.

Consilium autem do tanquam misericordiam consecutus a Domino. But I give my advice as one that has received mercy from the Lord.

I Cor. vii, 25. 


\section{Participles}

Ostendens se tanquam sit Deus. Showing himself. as if he were God.

II Thess. ii, 4 .

Diliges proximum tuum tanquam te ipsum. Thou shalt love thy neighbour as thyself.

Mk. xii, 3 I.

His qui sub lege sunt, quasi sub lege essem, cum ipse non essem sub lege, ut eos, qui sub lege erant, lucri facerem. To those that are under the law as if $I$ were under the law, althongh I was not under the law, that I might gain them that were under the law.

I Cor. ix, 20.

Carissimi, nolite peregrinari in fervore qui ad temptationem vobis fit, quasi novi aliquid vobis contingat. Beloved, do not be disturbed at the fiery trial which has come upon you to test you, as if some new thing were happening to you.

I Pet. iv, I 2.

Optulistis mihi hunc hominem, quasi avertentem populum. Ye have bronght to me this man as one that is turning away the people....

Lk. xxiii, I4.

Sic curro, non quasi in incertum: sic pugno, non quasi aerem verberans. So run I not as uncertainly: so fight I not as one that beateth the air.

I Cor. ix, 7 .

Sometimes a clause of consequence is expressed by sicut or sic followed by $e t$.

Fiat voluntas tua sicut in caclo et in terra. Thy will be done in earth as it is in heaven.

Mt. vi, Io.

\section{PAR'TICIPLES.}

176. A Participle is a verbal adjective sharing the characteristics of both verbs and adjectives.

As a verb it has a subject, and, if it is the Participle of a transitive verb, it has an object. It governs the same case as the verb from which it is derived. It has also tense and voice.

As an adjective it agrees with the noun which it qualifies in number, gender and case.

The Latin language is very short of Participles: it only has:

A Present Participle Active.

A Future Participle Active.

A Past Participle Passive.

In the case of deponent verbs the Past Participle is used in an active sense, as well as a passive. 


\section{Tenses of the Participles}

The time denoted by the tense of a Participle is relative to the time of the main verb, and not to the time of speaking, or writing.

177. Properly spealking the Present Participle denotes action going on at the same time as the action of the main verb, but in Ecc. L. the Present Participle is continually used to represent the Aorist Participle in Gk. and to denote action which took place before the action of the main verb. See examples.

The Future Participle denotes action which is expected to take place.

The Past Participle is also a Perfect Participle and so denotes past action complete and so continuing to have its effect at the time of the action of the main verb as well as simple past action.

178. Examples of the use of the tenses of the Participle:

Present Participle in the sense of action contemporaneous with that of the main verb.

Igitur qui dispersi erant pertransibant evangelizantes verbum. Those therefore that were scattered went everywhere preaching the word. Acts viii, 4:

Viri autem illi qui comitabantur cum eo, stabant stupefacti, audientes quidem vocem, neminem autem videntes. But the men who were travelling with him stood amazed, hearing the voice, but seeing no man.

Acts ix, 7 .

Notice the use of the Past Participle stupefacti in a Perfect sense.

Present Participle in the sense of action previous to that of the main verb.

Ascendens autem, frangensque panem et gustans, satisque allocutis usque ad lucem, sic profectus est. But having gone up and having broken bread and eaten, and having addressed them a long time even until daren, so he departed. Acts xx, I I.

Notice that the Present Participle and the Past Participle are used in exactly the same sense in this passage.

See also Mk. iii, I3; Eph. ii, I4, I5.

179. Future Participle in the sense of expected action.

Genimina viperarum, quis ostendit vobis fugere a ventura ira? O generation of vipers, who hath warned you to flee from the wrath to come? 
180. Past Participle in sense of past or perfect action.

Demoratus autem inter eos dies non amplius quam octo aut decem, descendit Caesaream. And having remained among them not move than eight or ten days he descended to Caesarea.

Acts xxv, 6.

181. A Participle may be used either adjectivally or adverbially.

When it is used adjectivally it limits the meaning of the noun which it qualifies just like an adjective. A participle may also be used by itself in this sense, the noun with which it agrees being understood. Adjectival Participles are generally best translated by an adjectival clause, an adjective or a noun.

When it is used adverbially it is equivalent to an adverbial clause modifying some verb in the sentence. Adverbial Participles are generally best translated by a suitable adverbial clause.

The context must decide which kind of adverbial clause the Participle in question is equivalent to. The Participle itself does nct denote time, purpose, cause, concession, or condition, but the context implies one of these ideas, and the Participle admits it.

Participles are used much more frequently in Latin than in Eng., and this is the reason why it is so often advisable to translate a Participle by a clause.

182. Adjectival Participles. These are generally best translated by a relative clause, or by a noun.

Nolumus autem vos ignorare, fratres, de dormientibus. But we do not wish you to be ignorant, brethren, concerning those that are asleep.

I Thess. iv, I3.

Quam pius es petentibus, sed quid invenientibus? How good thou art to those that seek, but what to those that find?

St Bernard.

Qua cessabunt persequentes, et regnabunt patientes. Where the persecutors shall cease, and the patient shall reign.

Hym. Lat.

The use of participles as nouns is characteristic of Late Latin.

Credentes $=$ believers. Diffidentes $=$ mbelievers .

Discentes $=$ disciples. 


\section{Participles used Adverbially}

\section{Adverbial Participles.}

Equivalent to a clause of Time.

Orantes autem, nolite multum loqui. But when ye pray, do not say much.

Mt. vi, 7 .

Oportuit ergo te mittere pecuniam meam nummulariis, et veniens ego recepissem utique quod meum est cum usura. You ought to have put out my money to the bankers, and then, when I came, I should have received my own with usury.

Equivalent to a clause of Cause.

Mt. $\mathrm{xxv}, 27$.

Peccavi tradens sanguinem justum. I have simed, because I have betrayed righteous blood.

Mț. xxvii, 4 .

See also Acts iv, 21, xii, 3; II Pet. i, 19.

Equivalent to a clause of Concession.

Et nullam causam mortis invenientes in eum, petierunt a Pilato ut interficerent eum. And although they found no cause of death in him, yet they asked Pilate that they might slay him.

See also II Pet. i, I2; Jude, 5. Acts xiii, 28.

Equivalent to a clause of Purpose.

The future participle is generally used in this sense; but in Ecc. I. a present participle may be so used.

Post autem annos plures eleemosynas facturus in gentem meam veni. But after many years I came to make offerings to my nation.

Acts xxiv, I7.

Sine videamus an veniat Helias liberans eum. Let us see if Elias will come to save him.

Mt. xxvii, 49 .

Vobis primum Deus suscitans Filium suum, misit eum benedicentem vobis. To you first God, having raised up his Son, sent him to bless you.

Acts iii, 26.

Equivalent to a clause of Condition.

Tempore enim suo metemus, non deficientes. For in his own time we shall reap, if we faint not.

Gal. vi, 9 .

A quibus custodientes vos, bene agetis. If ye reep yourselves from these, ye shall do well.

Acts Xv, 29.

See also Rom. ii, 27, xii, 20.

184. After verbs denoting ceasing, continuing, making an end or failing a participle is used to complete the sense, as in Gk.

Et factım est cum consummasset Jesus praecipiens dıo- 
decim discipulis suis.... And it came to pass when Jesus had made an end of giving commands to his twelve disciples....

Mt. xi, $x$.

Vos autem, fratres, nolite deficere bene facientes... But you, brethren, do not cease to do well.... II Thess. iii, I3.

Petrus autem perseveravit pulsans. But Peter continued knocking.

Acts xii, r6.

See also Acts v, 42; Eph. i, r6; Col. i, 9.

185. A peculiar use of the Present Participle which is an attempt to reproduce the Heb. Inf. Absolute is found in the Vg.

The Pres. Part. is used with a mood of the same verb to make a strong or positive statement.

Conterens non conteram domum Jacob. I will not utterly destroy the house of Jacob.

Amos ix, 8.

Videns vidi afflictionem populi mei. I have surely seen the affliction of my people.

Acts vii, 34 .

See also Heb. vi, I 4 ; Mt. xiii, I 4 .

The same sense may also be expressed by an Abl. of the Gerund or by the Abl. of a noun of lkindred meaning to the verb.

Praecipiendo praecipimus vobis ne doceretis in nomine isto. We have strictly charged you that ye should not teach in this name.

Acts $v, 28$.

Qui maledixerit patri vel matri, morte moriatur. Whosoever curses father or mother, let him surely die.

MIt. xv, 4 .

Desiderio desideravi hoc pascha manducare vobiscum antequam patiar. I have greatly desired to eat this Passover with you before I suffer.

Lk. xxii, 15 .

A Pres. Part. may also be used in the sense of the Abl. of the gerund.

Quis autem vestrum cogitans potest adjicere ad staturam suam cubitum unum? Which of y'ou by thinking can add one cubit to his stature?

Mt. vi, 27.

THE GERUND, GERUNDIVE PARTICIPLE AND SUPINE.

186. These parts of the Latin verb have no exact equivalents in Eng., although the Eng. verbal noun ending in ing is equivalent to some uses of the Gerund.

The Gerund and Supine are verbal nouns and the Gerundive is a verbal adjective.

The Nom. case of the verbal noun is expressed in Latin by the 


\section{Gerund and Gerundive}

Inf. and so is the Acc. case, except in uses where the verbal noun stands after a preposition.

The Gen., Dat. and Abl. cases of the verbal noun and the Acc. case, when standing after a preposition, are expressed by the Gerund.

The Gerund is not used very often in the $\mathrm{Vg}$.

For the sake of clearness some simple examples of each case of the verbal noun are given first and then some examples from the Vg. etc. Nominative. Edere jucundum est. To eat (or eating) is pleasant. Accusative. Dicit edere jucundum esse. He says that eating is pleasant.

Accusative (with a prep.). Omnia ad edendum parata sunt. All things are prepared for eating.

Genitive. Amor edendi magnum malum est. The love of eating is a great coil.

Dative. Dat operam edendo. He gives attention to eating. Ablative. Vivimus edendo. We live by eating.

187. Examples of the use of the Gerund in the Vg.:

Et dedit illis potestatem curandi infirmitates. And he gave them the power of curing diseases. Mk. iii, I5; Mt. xi, I5:

Deus autem spei repleat vos omni gaudio et pace in credendo. But may the God of hope fill you with all joy and peace in believing.

Rom. xv, I3.

Quae quaestum magnum praestabat dominis suis divinando. Who brought much gain to her masters by soothsaying.

Acts xvi, I6.

See also Acts x, 33; I Cor. xii, 24; I Tim. v, 2 I.

188. A peculiar use of the Abl. of the Gerund which is employed to translate a Present or Aorist Participle in the Gk. is found in the Vg. This is generally best translated by a present participle in Eng.

Qui pertransivit bene faciendo et sanando omnes oppressos a diabolo. Who went about doing good and healing all that were oppressed by the devil.

Acts $\mathrm{x}, 38$.

Hodie, in David dicendo, post tantum temporis.... Saying in David: "To-day, after so long a time...."

Heb. iv, 7 .

In casulis habitando cum Isaac.... Divelting in tents with Isaac....

Heb. xi, 9.

In quo et laboro, certando secundum operationem ejus, quam operatur in me in virtute. In which I also labour, working according to his operation which he works in me with power.

Col. i, 29. 
A similar use is found in the "Stabat Mater." Vidit suum dulcem Natum Moriendo desolatum.

And in Augustine:

Nec jam ingemiscebam orando ut subvenires mihi. Confess. vi, 3 .

189. In the Vg. translation of the Psalms (which is not Jerome's direct translation from the Heb., but a revised form of the Old Latin) the Abl. of the Gerund with in is found in a sense which is best translated into Eng. by a clause of time.

This is also found in Augustine.

Example:

In convertendo inimicum meum retrorsum... When mine enemy is turned back....

Ps. ix, 4 .

In deficiendo ex me spiritum meum, et tu cognovisti semitas meas. When my spirit failed within me, thou knewest my paths.

See also ci, 23, cxxv, I.

Ps. cxli, 4.

190. In Cl. L. if the verb is transitive and the object expressed the Gerundive Participle is generally used instead of the Gerund.

The Gerundive is not a noun, but an adjective, and, as such, agrees with its noun in number, gender and case.

As the Gerundive is in the passive voice in Latin and the verbal noun is in the active voice in Eng., the noun with which it agrees will be that which is the object of the verbal noun in Eng.

Thus where we write in Eng.:

They sent ambassadors for the sake of seeking peace, the Latin has something equivalent to:

They sent ambassadors for the sake of peace to be sought.

By a construction known as the Gerundive Attraction the word that would be the object if the Gerund were used is drawn into the case of the Gerundive, if this is in any other case than the Acc., and the Gerundive still agrees with it in number and gender.

Thus instead of the Gerund construction

Miserunt legatos ad petendum pacem,

we write

Instead of

Miserunt legatos ad petendam pacem.

Causa opprimendi legionem. For the sake of destroying the legion, we write Causa opprimendae legionis. 


\section{Gerund and Gerundive}

Instead of Opprimendo legiones. By destroying the legions, we write Opprimendis legionibus.

This Gerundive construction is nearly always used in the Acc. and Dat. and generally in the Gen. and Abl. The Gen. Pl. is avoided.

Examples of the Gerundive construction from the Vg.:

Ad dandam scientiam salutis plebi ejus.... To give the knowledge of salvation to his people... L Lk. i, 77.

Dico enim Christum Jesum ministrum fuisse circumcisionis, propter veritatem Dei, ad confirmandas promissiones patrum. For I say that Christ Jesus was a minister of the circumcision, on account of the truth of God, to confirm the promises of the fathers.

Rom. xv, 8.

See also Mt. xxvi, I2; I Thess. iii, 5.

191. In Ecc. L. the Gerund is found governing a direct object.

Hoc autem ipse de se, non profecto jactando virtutem, sed deflendo potius defectum, quem sibi per curam pastoralem incucurrisse videbatur, referre consueverat. This he used to say about himself, not certainly by way of boasting of his virtue, but vather by way of lamenting his shortcomings, which he seemed to have incurred throngh the pastoral office. Bede, Hist. Ecc.

Ego autem dico vobis: quoniam omnis, qui viderit mulierem ad concupiscendun eam, jam moechatus est eam in corde suo. But I say to you that every one who looketh on a woman to lust after her hath already committed adultery with her in his heart.

Mt. v, 28.

See also Mk. iii, I 5, quoted above, and Rom. i, 5.

192. In the Nom. case and the Acc. case (when used as the subject of an infinitive) the Gerund and the Gerundive have a meaning which is quite distinct from that which has been described above. They have a sense of obligation or duty.

The Gerund is used when the verb is Intransitive, or when the verb is Transitive and the object is not expressed.

As stated above, the Gerund is in the Active voice and the Gerundive is in the Passive voice and agrees with its subject in number, gender and case. 
The name of the person on whom the duty lies is put in the Dat. case. If the verb governs a Dat. the Abl. with $a$ is used to express the person on whom the duty lies, to avoid ambiguity.

Examples:

Gerund.

Currendum est mihi. I mist vun.

Parentibus nostris a nobis parendum est. We must obey our parents.

Gerundive.

Mater tua amanda est. Your mother is to be loved, or You must love your mother.

Hostes nobis vincendi sunt. The enemy are to be conquered by us, or We must conquer the enemy.

Examples from the $\mathrm{Vg}$. :

Gerund.

Horrendum est incidere in manus Dei viventis. It is a thing to be feared to fall into the hands of a living God.

Heb. x, 3I.

Qui praedicas non furandum, furaris? Thow who preachest that a man should not steal, dost thou steal? Rom. ii, 2I. Gerundive.

Filius hominis tradendus est in manus hominum. The Son of man must be given up into the hands of men. Mt. xvii, 22.

By a very exceptional construction the Gerundive is used in the sense of and parallel with the Future Participle.

At illi existimabant eum in tumorem convertendum et subito casurum et mori. But they thought that he would swell up and suddenly fall down and die.

Acts xxviii, 6.

\section{The Supine.}

193. The Supine ending in $\imath m$ expresses purpose. It is rare in Latin.

Et quicumque potum dederit uni ex minimis istis calicem aquae frigidae tantum...non perdet mercedem suam. And whosoever shall give only a cup of cold water to one of the least of these to drink. . he shall not lose his veward. Mt. $\mathrm{x}, 42$.

The Supine ending in $t$ is only used in certain expressions in the sense of the Abl. case of a verbal noun.

Auditu andietis et non intelligetis.... In hearing ye shall hear and shall not understand.... MIt. xiii, 14, from Isa. vi, 9. 


\section{Questions}

Qui ergo tribuit vobis Spiritum et operatur virtutes in vobis: ex operibus legis, an ex auditu fidei? He therefore that giveth to you the Spirit and worketh mighty works among you: doth he it by the works of the law, or by the hearing of faith?

See also Isa. ii, I6.

Gal. iii, 5 .

\section{METHODS OF ASKING QUESTIONS.}

194. In $\mathrm{Cl}$. L. direct questions which may be answered by either yes or $n o$ are expressed by adding the particle ne to an emphatic word at the beginning of the sentence.

In the Vg. there is often nothing but the context to show if a sentence is a question or not.

Pilatus vocavit Jesum et dixit ei: Tu es rex Judaeorum? Pilate called Jesus and said to him: Avt thou the king of the Jews?

Jn. xviii, 33 .

195. If an affirmative answer is expected to the question it is introduced by nonne and in the Vg. by an.

Domine, Domine, nonne in nomine tuo prophetavinus? Lord, Lord, did we not prophecy in thy name? Mt. vii, 22 .

An nescitis quoniam sancti de mundo judicabunt? Do ye not know that the saints shall judge concerning the world? I Cor. vi, 2.

See also Mt. xxvi, 53; Rom. iii, 29, vi, 3.

Numquid non is also found in the Vg. in this sense: Rom. $\mathrm{x}, \mathrm{I} 8$.

196. If a negative answer is expected to the question it is introduced by $n u m$ in $\mathrm{Cl}$. L. and by numquid in the $\mathrm{Vg}$.

Respondit Pilatus: Numquid ego Judaeus sum? Pilate answered: Am I a Jew?

Jn. xviii, 35 .

Num is apparently not found in the Vg. N.T. It is found in the O.T.

Num custos fratris mei ego sum? Am I my brother's keeper?

Both methods of asking a question are seen in this example:

Gen. iv, 9.

Alii dicebant: Hic est Christus. Quidam autem dicebant: Numquid a Galilaea venit Christus? Nonne scriptura dicit: Quia ex semine David...venit Christus? Others said: This is Christ. But certain said: Does Christ come out of Galilee? Does not the scripture say that Christ comes of the seed of David?

See also $M k$ iv, $2 \mathbf{r}$.

197. In the Vg. si is often used in imitation of Gk. to introduce both direct and indirect questions.

Dixitque ad eos: Si Spiritum Sanctum accepistis credentes? At illi dixerunt ad eum: Sed neque si Spiritus Sanctus est, audivimus.

See also Acts $x, 18, x x i, 37$.

Acts xix, 2. 
198. Questions may be introduced by the interrogative pronoun quis or by expressions compounded with it such as quomodo or ut quid, which is an imitation of the Gk. iva $\tau i$ or $\epsilon i$ s $\tau i$.

See Mt. ix, 4, nxvi, 8; Acts vii, 26; I Cor. $x, 29$.

Quid is used in the sense of $c u v=w h y$ in Mt. xx, 6 .

Alternative or donble questions are expressed by utrum...an, see Jn. vii, 17 , or by an alone in the second member of the question. The latter is the usual method in the $\mathrm{Vg}$.

Tu es qui venturus es, an alium expectamus? Art thou he that should come, or are we to look for another?

Mt. xi, 3 .

Quem vultis dimittam vobis: Barabbam, an Jesum qui dicitur Christus? Which do you wish that I should release for you: Barabbas, or Jesus who is called Christ?

Mt. xxvii, $\mathrm{r} 7$.

Notice the use of the interrogative pronoun quem here where utrum would have been used in $\mathrm{Cl}$. $\mathrm{L}$.

See also Jn. xviii, 34 .

\section{ADJECTIVES.}

199. An adjective whether used as an attribute of a noun or to complete a predicate agrees with the noun which it qualifies in number, gender and case.

Sometimes, however, if the noun is a collective noun, the adjective agrees rather with the idea that is signified by the noun than with the grammatical number and gender of the noun (constructio ad sensum).

Sed turba haec, quae non novit legem, maledicti sunt. But this crowd which knows not the law are cursed.

See also Jas. iii, 8; Rev. vii, 9.

Multitudo militiae caelestis laudantium Deum et dicentium.... A multitude of the heavenly host (of angels) praising God and saying....

Lk. ii, 13.

200. Adjectives are often used as equivalent to nouns, the masculine denoting men, or people in general of the kind described by the adjective, the feminine women, the neuter things.

Resurrectio justorum et iniquorum. A resurrection of the just and the unjust.

Acts xxiv, 15 .

Invisibilia enim ipsius...per ea quae facta sunt intellecta conspiciuntur. For the invisible things of him... being understood by the things that are made, are perceived.

Rom. i, 20.

The neuter of the adjective may be used in the sense of an abstract noun. Salutare $=$ salvation, Lk ii, 30 .

201. The adjective unus is used in the Vg. in the sense of the indefinite article This use became general in the Romance languages. 


\section{Comparison of Adjectives}

Et accessit ad eum una ancilla dieens: Et tu cum Jesu Galilaeo eras. And there came to him a maid and said: Thou also wert with Jesus the Galilaean.

See also Mt. xxi, 19.

IIt. xxvi, 69.

202. The adjective omnis is used with a negative to express a strong negative statement or command in imitation of Heb.

Et nisi breviati fuissent dies illi, non fieret salva omnis earo.... And unless those days had been shortened, no living thing would be saved.

IIt. xxiv, 22.

Omnis sermo malus ex ore vestro non procedat. Let no corrupt speech proceed out of your moutil.

See also Rom. iii, 20; I Cor. i, 29; Rev. xviii, 22.

Eph. iv, 29.

\section{Comparison of Adjectives.}

203. The positive degree of an adjective may be used in the Vg. in the sense of a comparative.

Bonum est tibi...in vitam intrare...quam mitti in gehennam. It is better for the to enter into life than to be cast into Gehenna.

The positive may be used in the sense of a superlative.

Mt. xviii, 9 .

Quod est magnum mandatum in lege? Which is the greatest commandment in the law?

The comparative may be used in the sense of a superlative.

Major autem horum est charitas. But the greatest of these is love.

I Cor. xiii, I3.

The superlative may be used in the sense of the comparative.

Quod minimum quidem est omnibus seminibus. Which indeed is less than all seeds.

Mt. xiii, 32 ; Heb. xi, 4.

204. The ordinary const. after an adj. in the comparative degree in C1. L. to express the object with which the comparison is made is to put the word which denotes this object in the Abl. case, or to use quam.

Amen dico vobis, non surrexit inter natos mulierum major Johanne Baptista. Verily I say to you, there has not arisen any one greater than John the Baptist among those born of women.

Mt. xi, I I.

Qui amat patrem aut matren plus quam me, non est me dignus. He who loves father or mother more than me is not worthy of me.

Mt. $x, 37$.

In the Vg. in imitation of Heb. the preps. $a$, ex, prae, super may be used after an adjective in the comparative degree, or even a Gen. case, in imitation of $\mathrm{Gk}$.

See Lk. xiii, 2, xviii, I 4; II Cor. xii, I I; Heb. ii, 7, iii, 3; Ps. xviii, I I, cxxxviii, 6, and section 32 of this book. 


\section{PREPOSITIONS.}

205. The use of prepositions in Ecc. L. differs somewhat from their use in $\mathrm{Cl}$. L.

This is due in the first place to the natural development of the language. Prepositions are used with increasing frequency in the place of simple cases, until, in the Romance languages, they have replaced the cases altogether.

In the Vg. the influence of Heb., felt through the LXX and also in the direct translation of the O.T. by Jerome, has given rise to some very peculiar methods of expressing comparison and the instrument, by means of prepositions.

Greek is rich in prepositions and in delicate shades of meaning expressed by using the same preposition with different cases.

The Latin translators have on the whole been very successful in rendering these Gk. prepositions into Latin; but, in so doing, they have somewhat deviated from normal Latin usage.

It has been thought well to give the Gk. originals of which the usages of the Latin prepositions given below are translations.

\section{Prepositions governing an Ablative case.}

206. $A, A b, A b s$. Usual meaning from, or by (of the agent). Representing Gk. a'só, vimó with gen., rarely $\epsilon^{\prime} \kappa$, and in comparisons $\pi \alpha \rho a ́$ with accusative or genitive, or simple genitive.

Discedite a me qui operamini iniquitatern. (ámó.)

Omnia mihi tradita sunt a Patre meo. (ínó.) Mt. vii, 23. Mt. xi, 27. In Late Latin $a$ is used even with the names of towns etc.

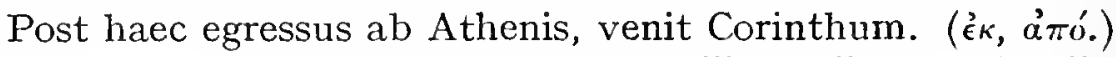
Acts xviii, I, xii, 25; Mk. vii, I.

So it is used of the Instrument:

Ecce et naves. . circumferuntur a modico gubernaculo. (i்ó.)

Other uses to translate Gk. ámó and '́к. Jas. iii, 4 . Attendite a falsis prophetis.... (ámó.) Mt. vii, I5, x, I7. Invenit. . . hominem. . ab annis octo jacentem in grabatto... ('́). Acts ix, 33. Jesum a Nazareth.... (ámó.)

Acts $\mathrm{x}, 38$; Mk. xv, 43; Jn. i, 44. Perdidisti omnes qui fornicantur abs te. (ámó.) Ps. lxxii, 27. 


\section{Absque. Coram. Clam. Cum}

$A$ is used in comparisons even where there is no adjective or adverb in the comparative degree in imitation of Heb.

Nihil enim minus fui ab iis.... (Gen.)

II Cor. xii, II.

Descendit hic justificatus in domum suam ab illo. ( $\pi \alpha \rho a ́$, acc.)

Minuisti eum paulominus ab angelis. ( $\pi \alpha \rho a ́$, acc.)

Lk. xviii, I4.

Heb. ii, 7, from Ps. viii, 6.

Et a te quid volui super terram? '( $\pi \alpha \rho \alpha$, gen.) Ps. lxxii, 25. In the Psalms $a$ is used in the sense of because of.

A voce gemitus mei adhaesit os meum carni meae. (ámó.)

Ps. cii, 6, I I, xxxvii, 6; xliii, I7.

207. Absque. Not used in Cl. L. In Early and Late Latin used in sense of sine $=$ without.

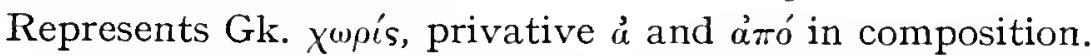

Tentatum autem per omnia pro similitudine absque peccato. ( $\chi$ wpís.)

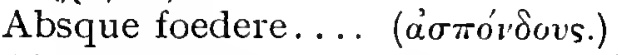

Heb. iv, I5.

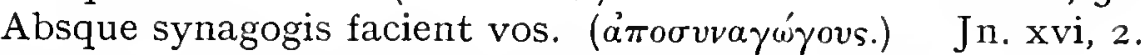

208. Coram. Usual meaning in the presence of, openly, before.

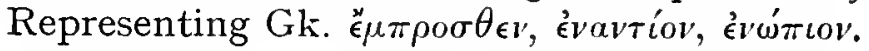

Sic luceat lux vestra coram hominibus.... ( $\epsilon^{\prime} \mu \pi \rho o \sigma \theta \epsilon v$.)

Mt. $v, \mathrm{r} 6$.

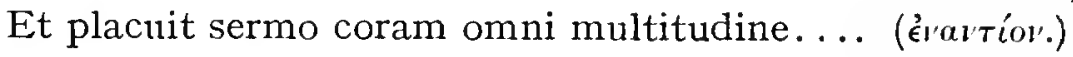

Acts vi, 5, viii, 32 .

Peccantes coram omnibus argue. ('́v

209. Clam. Usual meaning secretly.

Not used as a preposition in the N.T. but as an adverb, to translate $\lambda \alpha^{\prime} \theta \rho \alpha$, Mt. ii, 7 .

Used as prep. in Gen. xxxi, 26, xlvii, I8.

210. Cum. Usual meaning together with, in company with, also used to express the manner in which an action is done.

Representing Gk. $\mu \epsilon \tau \dot{\alpha}$ with gen., $\sigma v^{\prime} v^{\prime}, \epsilon^{\prime}$, or the simple dative. Filius enim hominis venturus est in gloria Patris sui cum angelis suis.... ( $\mu \in \tau$ ú.)

Mt. xvi, 27.

Et rogabat illum vir, a quo daemonia exierant, ut cum eo esset. $(\sigma u ́ v$.

Lk. viii, 38 .

Et loquebantur verbum Dei cum fiducia. ( $\mu \in \tau \dot{\text {. }}$ ) Acts iv, $3^{\mathrm{I}}$. 
So it is used to express manner even with nouns qualified by an adjective where a simple ablative is generally used in $\mathrm{Cl}$. L.

Regressus est cum magna voce magnificans Deum. ( $\mu \in \tau$ á.)

Lk. xvii, I 5 .

Cum bona voluntate servientes, sicut Domino, et non hominibus. ( $\mu \in \tau \alpha^{\prime}$.)

Eph. vi, 7 .

Carcerem quidem invenimus clausum cum omni diligentia.... ( $\boldsymbol{c}^{\prime} \mathrm{r}^{\prime}$ )

Acts $\mathrm{v}, 2.3$.

Instrumental use (very rare in Classics, see Verg. Aen. ix, 8I6).

Et redemptorem misit cum manu angeli, qui apparuit illi in rubo. ( $\sigma v^{\prime} v^{\prime}$ ) Acts vii, 35 .

Replebis me jucunditate cum facie tua. ( $\mu \in \tau a ́$.

Acts ii, 28.

Cum impositione manuum presbyterii. ( $\mu \in \tau \dot{\alpha}$.) I Tim. iv, I4. In the following passages $\mathrm{cum}$ is used to trans. $\mu \in \tau \alpha$ '.

Facere misericordiam cum patribus nostris.

Rationem ponere cum servis....

Lk. i, 72. Mt. xviii, 23.

211. De. Usual meaning from, down from, concerning, made from. The favourite preposition of Late Latin, used where Cl. L. would use $e x$ or a simple Gen. Compare the use of de in French in the sense of from and also of.

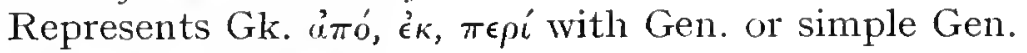

From, down from.

Numquid colligunt de spinis uvas, aut de tribulis ficus? (ámó.) Mt. vii, I6.

Cum autem descendisset de monte... (ảmó.) Mt. viii, 1 . Facite vobis amicos de mamona iniquitatis. ( $\epsilon^{\prime} \kappa$.)

Lk. xvi, 9 .

Concerning.

De his quae dicta sunt a pastoribus ad ipsos. ( $\pi \epsilon \rho i$.

Lk. ii, I 8 .

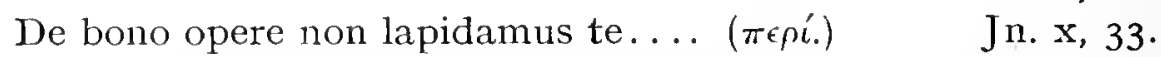

Deus filium suum mittens in similitudinem carnis peccati et de peccato, damnavit peccatum in carne. ( $\left.\pi \epsilon \epsilon^{\prime}.\right)$ Rom. viii, 3 . In the sense of out of.

Baptizatus autem Jesus, confestim ascendit de aqua. (ámó.) Mt. iii, I6.

De corde enim exeunt cogitationes malae.... ( $\left.\dot{(}^{\kappa} \kappa.\right)$

Mt. xv, I9. 
In the sense of denoting the material of which a thing is made.

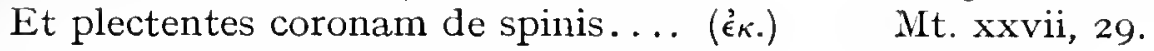

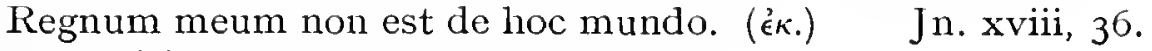
In a partitive sense representing Gk. gen.

Quamdiu non feceritis uni de minoribus his, nec mihi fecistis.

Effundam de Spiritu meo.... Acts ii, 18 .

Mt. xxv, 45 .

212. E, Ex. Usual sense out of, from within.

Representing Gk. $\dot{\epsilon} \kappa$ or $\dot{\epsilon} \xi$.

In the Vg. and Late Latin de is used where ex would be used in Cl. L. Ex is generally used in a metaphorical sense.

Et diliges Dominum Deum tuum ex toto corde tuo. Mk. xii, 30 . Eis autem qui sunt ex contentione.... Rom. ii, 8.

Si enim qui ex lege heredes sunt, exinanita est fides....

Justus ex fide vivet.

Rom. iv, I4.

Gal. iii, I I.

Ex may also be used in a partitive sense to translate the Gk. partitive gen.

Quamdiu fecistis uni ex his fratribus meis minimis, mihi fecistis.

Mt. xxv, 40.

Compare the use of de in verse 45 .

Ex may be used in comparison in imitation of Heb.

Mirabilis facta est scientia tua ex me. Ps. cxxxviii, 6 .

213. Pro. Usual meaning for, on behalf of, instead of, before.

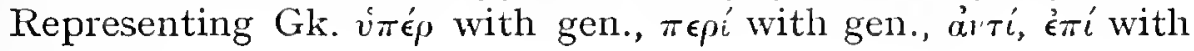
genitive.

Orate pro persequentibus et calumniatoribus vestris. (víté.)

IIt. $v, 44$.

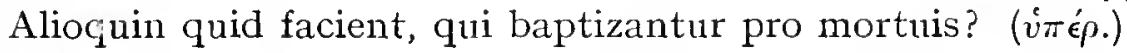

I Cor. $\mathrm{xv}, 29$.

Et panis, quem ego dabo, caro mea est pro mundi vita. (

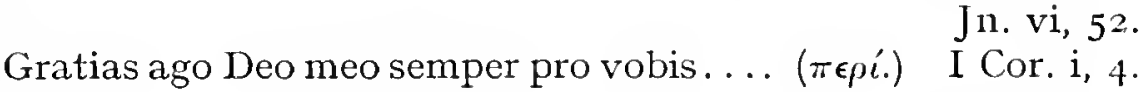
Archelaus regnabat in Judea pro Herode patre suo. (ávi $i_{\text {.) }}$

Mit. ii, 22.

Statuto autem die Herodes vestitus veste regia sedit pro tribunali. ('́mí)

Acts xii, $2 \mathrm{r}$.

Exceptional use.

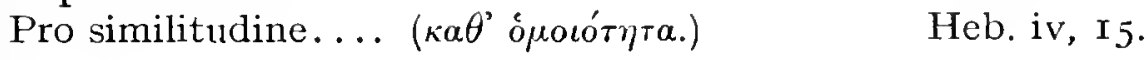


214. Prae. Usual meaning before, because of, compared with.

Representing a number of Gk. prepositions in sense of because of, such as $\delta\left\llcorner a\right.$ with accusative, $\alpha \pi o^{\prime}, \dot{\epsilon} \kappa, \epsilon^{\prime} v$.

When used in the sense of compared with is translated by Gk. $\pi \alpha \beta a ́$ with accusative.

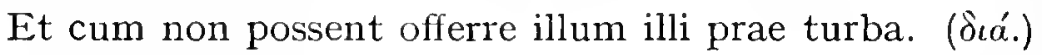

Mk. ii, 4.

Dormientes prae tristitia.... (ảmó.)

Lk. xxii, 45 .

Et cum non viderem prae claritudine luminis... (ámó.)

Acts xxii, II.

Prae confusione sonitus maris.... $\left(\dot{\epsilon}^{\prime} v.\right)$

Lk. xxi, 25.

Et blasphemaverunt Deum caeli prae doloribus et vulneribus suis. ('́к.')

Rev. xvi, I I.

Putatis quod hi Galilaei prae omnibus Galilaeis peccatores fuerunt quia talia passi sunt? ( $\pi \alpha \rho \alpha$.)

Lk. xiii, 2. Amplioris enim gloriae iste prae Moyse dignus est habitus.... (тара́.)

Heb. iii, 3 .

215. Sine. Usual meaning without.

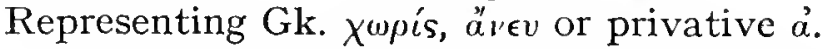

Arbitramur enim justificari hominem per fidem sine operibus legis. ( $x \omega$ pós.) $^{\prime}$

Rom. iii, 28; Jas. ii, I 8.

Et unus ex illis non cadet super terram sine Patre vestro. $\left(\ddot{u}_{v^{\prime} \in v}\right.$.)

Mt. $x, 29$.

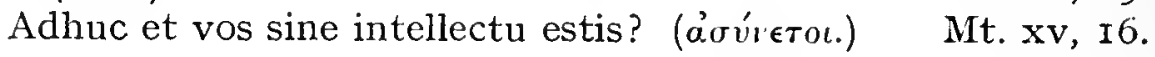

Prepositions governing the Accusative Case.

216. Ad. Usual mcaning To, into (of motion to), at, near, according to.

Generally represents the Gk. Tpós with acc. or dat., or eis, sometimes katá with acc.

It is used in the $\mathrm{Vg}$. after verbs of speaking where the dat. would be used in $\mathrm{Cl}$. L.

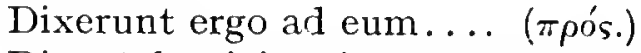

Jn. vi, 28.

Disputabat igitur in synagoga cum Judaeis et colentibus et in

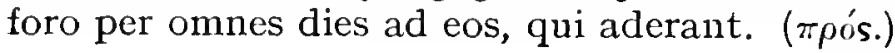

Acts xvii, 17.

The following uses, most of which may be parallelled from the Classics, may be noted. 


\section{Adversus. Ante}

With a view to, for, resulting in.

Cognoscebat autem illum, quod ipse erat, qui ad eleemosynam

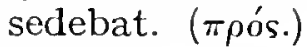

Ad victimam taurus ducitur. Acts iii, ro; Col. ii, 23.

Corde enim creditur ad justitiam: ore autem confessio fit ad salutem. (єis.)

Rom. x, io.

At, near, by the side of, at the sight of.

Petrus autem stabat ad ostium foris. ( $\pi$ oós with dat.)

Jn. xviii, 16.

Intrantes autem juvenes invenerunt illam mortuam: et extulerunt et sepelierunt ad virum suum. ( $\pi \rho o^{\prime}$, acc.)

In Mt. $\mathrm{xx}, 2 \mathrm{I}$ to translate $\dot{\epsilon} \xi$.

Acts v, Io; II Cor. v, 8.

Cum ad crucem Domini confundantur sidera. Cyp. de Pat. Because of.

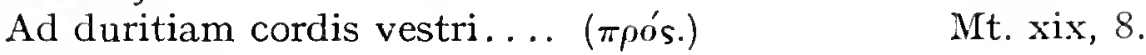
According to.

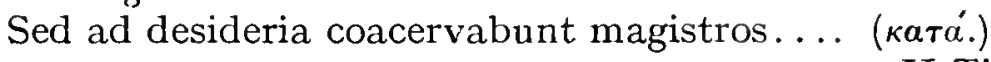

II Tim. iv, 3 .

Used to translate $\pi \rho o ́ s$ in various senses (not Classical).

Ad horam. For an hour. Jn. v, 35; II Cor. vii, 8 . Ad ullum verbum.

Mt. xxvii, I4.

Exceptional use:

Ad manus illum trahentes. ( $\chi \epsilon \iota \rho \alpha \gamma \omega \gamma o \hat{v} v \tau \epsilon s$.$) \quad Acts ix, 8$.

217. Adversus. Usual meaning against.

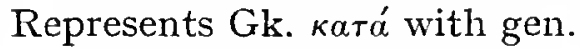

Nolite gloriari et mendaces esse adversus veritatem.

Jas. iii, I4; I Cor. xv, I5.

218. Ante. Ordinary meaning before both of place and time.

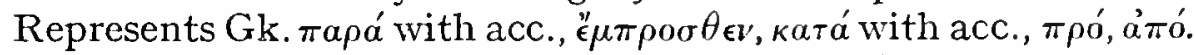

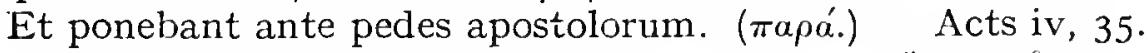

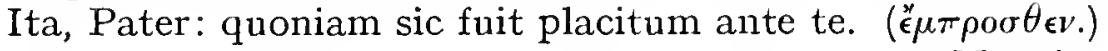

Mt. xi, 26.

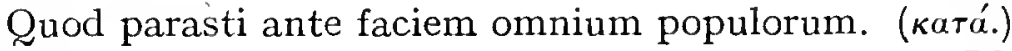

Lk. ii, 3 I.

Scio hominem in Christo ante annos quattuordecim.... ( $\left.\pi \rho c^{\prime}.\right)$

Exceptional use:

II Cor. xii, 2.

Erat velatum ante eos.... (ámó.)

Lk. ix, 45 . 


\section{I06 Apud. Circa. Contra. Erga. Inter}

219. Apud. Ordinary meaning by, near, in the house of, in the presence of.

Representing Gk. $\pi \alpha \rho a ́$ with dat., $\pi \rho o$ s with acc. and dat., $\epsilon \pi i$ with gen.

Apud quem hospitaremur.... ( $\pi \alpha \rho a ́$, with dat.)

Acts xxi, I6; Col. iv, I6.

Et nunc clarifica me tu, Pater, apud temetipsum. ( $\pi \alpha \rho a ́$, dat.) Jn. xvii, 5 .

Apud homines hoc impossibile est. ( $\pi \alpha \rho \alpha$, with dat.)

Et verbum erat apud Deum. ( $\pi \rho o ́ s$, acc.)

Mt. xix, 26. Jn. i, I. Audet aliquis... judicari apud iniquos, et non apud sanctos? ('́mí, gen.)

I Cor. vi, I.

220. Circa. Usual meaning about, around, concerning. Representing Gk. кuтá with acc., $\pi \epsilon \rho i$ with acc.

Circa domos. (ката́.)

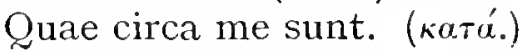

Circa frequens ministerium. ( $\pi \epsilon \rho i$.)

Acts ii, 46 . Eph. vi, 2 I.

Habens fidem et bonam conscientiam, quam quidam repellentes, circa fidem naufragaverunt. ( $\pi \epsilon \rho i$.)

I Tim. i, I9.

In Mk. iv, 4 circa is used to translate $\pi \alpha p \alpha$ instead of secus.

221. Contra. Usual meaning against, over against. Representing Gk. катá with gen.

Non post multum misit se contra ipsam ventus Typhonicus...

Acts xxvii, I4.

222. Erga. Usual meaning towards, with respect to.

Representing Gk. $\pi \epsilon \rho i$ with acc.

Sollicita es, et turbaris erga plurima.

Lk. x, 4 I ; Phil. ii, 30.

223. Inter. Usual meaning among, between.

Represents Gk. '́' '.

Non ita erit inter vos. $(\dot{\epsilon} v$. $)$

Mt. $\mathrm{xx}, 26$.

Inter vos $=\mu \epsilon \tau^{\prime} \alpha^{\prime} \lambda \lambda \eta^{\prime} \lambda \omega \nu$. Jn. xvi, I9.

Also used to express a superlative in accordance with Heb. usage.

Benedicta tu inter mulieres. ('́ $\boldsymbol{v} \cdot$.)

Lk. i, $4^{2}$. 


\section{Juxta. Penes. Praeter. Per}

224. Juxta. Usual meaning near, according to.

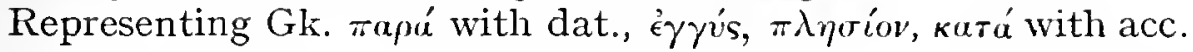
Stabant autem juxta crucem Jesu mater ejus et soror matris ejus. (mapá.)

Jn. xix, 25.

Erat enim Johannes baptizans in Aenon juxta Salim. ('́ $\gamma \gamma \gamma$ v́s.)

Quare non ambulant juxta traditionem seniorum? $\begin{aligned} & \text { Jn. iii, } 23 . \\ & (\kappa a \tau \alpha ́ .)\end{aligned}$

Mk. vii, 5 .

Also in sense of along.

Ambulans autem Jesus juxta mare Galilaeae. ( $(\pi a \rho a ́$, with acc.)

Mt. iv, I 8 .

225. Penes. Usual meaning in possession of.

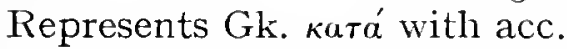

Tu fidem habes? penes temetipsum liabe coram Deo.

Rom. xiv, 22.

226. Praeter. Usual meaning besides, except, beyond.

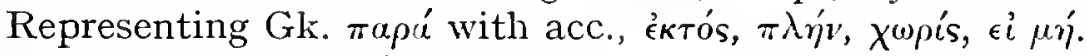

Fundamentum aliud nemo potest ponere praeter id quod positum est. ( $\pi \alpha \rho a ́$.) I Cor. iii, I I.

Omnia subjecta sunt ei, sine dubio praeter eum, qui subjecit. ei omnia. ('́kтós.)

I Cor. xv, 27.

Praeter illa, quae extrinsecus sunt, instantia mea quotidiana, sollicitudo omnium ecclesiarum. ( $\chi \omega$ pís.) II Cor. xi, 28.

Nihil invenit praeter folia. ( $\left.\epsilon i \mu \dot{\eta}^{\prime}\right)$ Mk. xi, I3.

In the sense of contrary to.

Rogo...ut observetis eos, qui dissensiones et offendicula

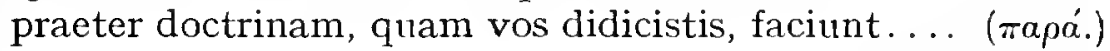

Rom. xvi, I7.

Also Gal. i, 9 .

In the sense of more than.

Putatis quia et ipsi debitores fuerunt praeter omnes homines habitantes in Jerusalem? (mapá.) Lk. xiii, 4.

227. Per. Usual meaning through, of place or time, by means of, by in oaths.

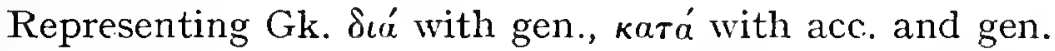

Praeceptor, per totam noctem laborantes, niliil cepimus.... $(\delta\llcorner a ́)$.

Lk. v, 5 .

Et ipse iter faciebat per civitates et castella. ( $\kappa a \tau a ́$, acc.)

Lk. viii, I. 
Distributively'.

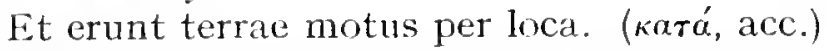
Mk. xiii, 8. of repetition.

Per omnes annos. (кат' '́тоs.)

Per omne sabbatum.

Per omnia.

Lk. ii, 4 I. Acts XV, 2I. Heb. iv, I 5 . By means of.

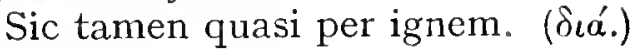

I Cor. iii, I5. In oaths.

Adjuro te per Deum vivum. (катá, gen.) Mt. xxvi, 63.

228. Propter. Usual meaning on account of, because of .

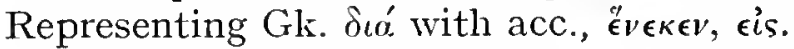

Sabbatum propter hominem factum est, et non homo propter sabbatum. $(\delta \iota \alpha$. $)$

Mk. ii, 27.

Quare et vos transgredimini mandatum Dei propter traditionem vestram? ( $\left.\delta \iota \alpha^{\prime}\right)$

Mt. $x v, 3$.

Beati, qui persecutionem patiuntur propter justitiam. ( $\epsilon^{\prime \prime} \boldsymbol{\epsilon} \kappa \epsilon \nu$.)

Mt. v, Io.

Cum venissem autem Troadem propter evangelium Christi.... (eis.)

II Cor. ii, I2.

229. Post. Usual meaning after, behind.

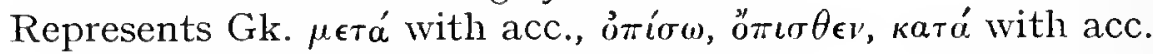

Statim autem post tribulationem dierum illorum sol obscurabitur. ( $\mu \in \tau a ́$.

Mt. xxiv, 29.

Post velamentum autem secundum, tabernaculum, quod dicitur Sancta Sanctorum. ( $\mu \epsilon \tau a ́$.)

Heb. ix, 3 .

Dimitte eam quia clamat post nos. (ǒ $\pi \iota \sigma \theta \epsilon$.$) \quad Mt. xv, 23$. Magis autem eos, qui post carnem in concupiscentia immun-

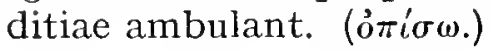

Unus post unum. ( $\left(\hat{i} \boldsymbol{i} \kappa \alpha \theta^{\prime} \epsilon \hat{i}\right.$. $)$

II Pet. ii, Io. Jn. viii, 9 .

230. Secundum. Usual meaning after, according to.

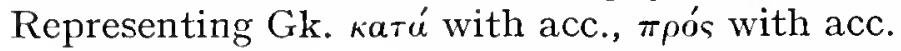

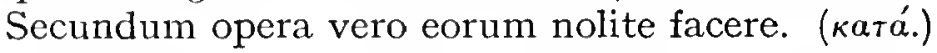

Mt. xxiii, 3 .

Qui autem scrutatur corda, scit quid desideret Spiritus: quia secundum Deum postulat pro sanctis. ( $\kappa \alpha \alpha^{\prime}$.) 


\section{Secus. Supra}

Ergo, fratres, debitores sumus non carni, ut secundum carnem

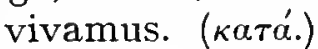

Rom. viii, I 2.

Et non facit secundum voluntatem ejus.... ( $\pi$ pós.)

Lk. xii, 47 .

231. Secus. Usual meaning otherwise. In the Vg. and Late

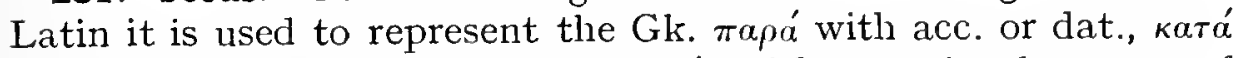
with acc., $\dot{\epsilon} \pi i$ with gen. or acc., $\pi$ oós with acc., in the sense of along, beside ${ }^{1}$, at.

In illo die exiens Jesus de domo sedebat secus mare. ( $\pi a \rho \alpha a$, acc.)

IIt. xiii, I.

Jesus... apprehendit puerum, et statuit illum secus se. ( $\pi \alpha \rho \alpha^{\prime}$, dat.)

Lk. ix, 47 .

Similiter et Levita cum esset secus locum.... (катú, acc.)

Lk. $\mathrm{x}, 32$.

Et huic erat soror nomine Maria, quae etiam sedens secus pedes Domini, audiebat verbum illius. ( $\pi \rho \circ$ s, acc.)

Lk. $\mathrm{x}, 39$.

Secus littus sedentes.... (̇ं $\pi \dot{i}$, acc.)

Mt. xiii, 48 .

Et videns fici arborem unam secus viam.... ('̇ $\pi \dot{\imath}$, gen.)

Mt. xxi, I9.

For a very peculiar use see Lk. xx, 37 .

Quia vero resurgant mortui, et Moyses ostendit secus rubum.

Moses showed in the place of the Scripture concerning the bush. ('̇สí, gen.)

232. Supra. Usual meaning on, upon, above, beyond.

Representing Gk. $\dot{\epsilon} \pi \dot{\prime} v(\omega, \dot{\epsilon} \pi \dot{i}$ with acc. gen. dat., $i \pi \dot{\epsilon} \rho$ with acc.

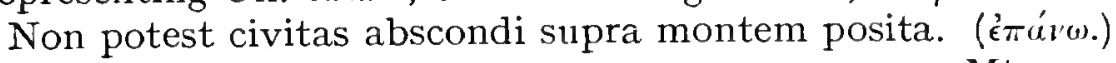

Invenit puellam jacentem supra lectum. ('́mí, acc.)

Mt. v, I 4 .

Mk. vii, 30 .

Venit ad eos ambulans supra mare. ('̇ $\pi i$, gen.) Mk. vi, 48.

Vere dico vobis quoniam supra omnia quae possidet, constituet illum. ('́) $\pi \dot{\prime}$, dat.)

Lk. xii, 44 .

Et proficiebam in Judaismo supra multos coaetaneos meos. (vं $\pi^{\prime} \rho$, acc.)

Gal. i, I 4.

1 In an inscription we find: Aedificia quae sunt juxta ex utraque parte secus viam. 
Prepositions governing both the Ablative AND ACCusative Cases.

233. In with the Ablative. Usual meaning in, at.

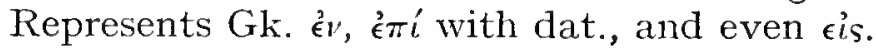

In Late Iatin used with names of towns etc.

Quia si in Tyro et Sidone factae essent virtutes.... ('́

Mt. xi, 21.

Viri astiterunt in domo. ( $\left.\epsilon^{\prime} v^{\prime}.\right)$ Acts $x i$, I I. Used to express the time when anything happens, where a simple Ablative would generally be used in Cl. L.

In diebus autem illis venit Johannes Baptista, praedicans in deserto Judaeae. ( $\left.\boldsymbol{\epsilon}^{\prime} r^{\prime}.\right)$ Mt. iii, I. Used in the $\mathrm{Vg}$. of the Instrument or Agent in imitation of Heb. ๖. also to express manner.

Domine, si percutimus in gladio? ('́v.) Lk. xxii, 49.

Hoc genus in nullo potest exire, nisi in oratione et jejunio. ( $\dot{\epsilon} v$.) Mk. ix, 28.

Quia in potestate et virtute imperat immundis spiritibus. ( $\left.{ }^{\prime}{ }^{\prime}{ }^{\prime}.\right)$ Lk. iv, 36 .

Hic ejecit daemones in Beelzebub. $\left({ }^{\prime} \boldsymbol{t}^{\prime}.\right)$

Mt. xii, 24.

In quo judicaturus est orbem in aequitate in viro, in quo statuit. ('́t'.)

In sense of because of, at.

Acts xvii, 3I.

Per totam noctem laborantes nihil cepimus: in verbo autem tuo laxabo rete. ('́ $\pi \boldsymbol{i}$, with dat.)

Lk. v, 5, 9 .

Etsi omnes scandalizati fuerint in te, ego numquam scandalizabor. ('́ $\left.v^{\prime} \cdot\right)$

Mt. xxvi, 33 .

Putant quod in multiloquio exaudiantur. ('ُ).) Mt. vi, 7. See also Ps. v, 8; Acts iii, Io, iv, 9, vii, 29; I Cor. i, 4 ; I Pet. iv, I 4. To express accompaniment.

Quoniam Dominus in jussu, et in voce archangeli, et in tuba Dei descendet de caelo. ( $(\epsilon)$ I $)$ I Thess. iv, I6. Et ego cum venissem ad vos, fratres, veni non.in sublimitate sermonis aut sapientiae.... ( $\left(\kappa \alpha \theta^{\prime} \dot{v} \pi \epsilon \rho \circ \chi \eta^{\prime} v^{\prime}\right)$

Homo in spiritu immundo.... (') $\left.\boldsymbol{\epsilon}_{\boldsymbol{v}}.\right)$

In the sense of concerning, with regard to $=$ eis.

Sacramentum hoc magnum est, ego autem dico in Christo et in ecclesia.

Eph. v, 32.

See also Heb. vii, I 4 . 
Ut $\operatorname{sim}$ minister Christi in gentibus....

Rom. xv, i6.

In with the Ablative is used in certain passages, where $i n$ with the Accusative would have been expected. = $\epsilon i$.

(I) After verbs of motion:

Beatus homo qui non abiit in consilio impiorum....

$$
\text { Ps. i, I. }
$$

(2) To express the object or end of an action:

Infirmum in fide assumite, non in disceptationibus cogitationum.

Rom. xiv, I.

An ignoratis quia quicumque baptizati sumus in Christo Jesu in morte ipsius baptizati sumus?

Rom. vi, 3 .

In is used to translate the Heb. $\unlhd$ in a passage which denotes the form under which anything appears (French $e n$ ).

Qui apparui Abraham, Isaac et Jacob in Deo Omnipotente. Ex. vi, 3.

234. In with the Accusative. Usual meaning into.

Representing Gk. $\epsilon \dot{\imath}$, also rarely $\dot{c}^{\prime}$.

Used in Late Latin with names of towns etc.

Mitte viros in Joppen.

Introivit in domum.

Acts $x, 5$.

Acts ix, I7; Lk. xxii, Io.

In a pregnant sense giving the result of the action of the verb.

Ecce viri, quos posuistis in carcerem, sunt in templo.... $\left({ }^{\prime} v^{\prime} \cdot\right)$

Acts v, 25 .

Qui exiit primo mane conducere operarios in vineam suam. ( $\left.\epsilon i s_{\text {. }}\right)$

MIt. $\mathrm{xx}, \mathrm{I}$.

Liberabit me Dominus ab omni opere malo et salvum faciet in regnum suum caeleste. (eis.) II Tim. iv, I8.

Used in a predicate to express result:

Iapidem, quem reprobaverunt aedificantes hic factus est in caput anguli. ( $\epsilon i$ is.)

Et nutrivit eum sibi in filium. (eis.)

It. xxi, 42 .

Acts vii, 2r.

Used to express purpose:

Emerunt ex illis agrum figuli in sepulturam peregrinorum. ( $\epsilon$ is.)

Mt. xyvii, 7, 1o.

Posui te in lucem gentium. ( $\epsilon$ is.) Acts xiii, 47 .

Ego quidem baptizo vos in aqua in poenitentiam. (Eis.)

Mt. iii, II.

Segregatus in evangelium Dei. (єis.)

Rom. i, I.

Ita et isti nunc non crediderunt in vestram misericordiam.... (Simple dat.)

Rom. xi, 3I. 
In the sense of concerning.

David enim dicit in eum.... (єis.)

Acts ii, 25 .

Nolite ergo solliciti esse in crastinum. (eis.) Mt. vi, 34.

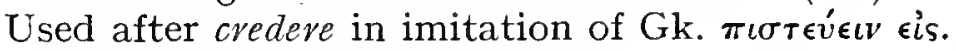

Tu credis in Filium Dei? ( $\epsilon i s$.

Jn. ix, 35 .

235. Sub. Usual meaning: $s u b$ with $\mathrm{Abl}$. =under, below, in the sense of remaining under. Sub with Acc. $=$ movement to or from under.

In the Vg. sub is generally used with the Abl. in all senses.

Represents Gk. vimó with acc. and gen., émi with gen. and dat.

Nam et ego sum homo sub potestate. (vंró, acc.) Mt. viii, 9.

With a verb of motion:

Omnia mihi licent, sed ego sub nullius redigar potestate. (vimó, gen.)

I Cor. vi, I2.

In the sense of in the time of.

Et multi leprosi erant in Israel sub Elisaeo propheta.... ('érí, gen.)

See also Lk. iii, 2.

To translate $\dot{\epsilon} \pi i$ with gen. in the sense of in the presence of.

Adversus presbyterum accusationem noli recipere, nisi sub duobus aut tribus testibus. I Tim. v, 19; also vi, I3. Exceptional use to translate $\dot{\epsilon} \pi \dot{\imath}$ with dat. in sense of concerning.

A tribulatione, quae facta fuerat sub Stephano. Acts xi, I9.

236. Super. Usual meaning: super with $\mathrm{Abl}$. = concerning, about, because of, rarely $=$ on. Super with Acc. $=$ over, on the top of, beyond, above.

(I) With the Abl. representing Gk. $\dot{\epsilon} \pi i$ with dat. or gen., $v \pi \dot{\epsilon} \rho$ with gen., $\pi \epsilon \rho i$ with gen.

Contristatus super caecitate cordis eorum.... ('̇ $\pi \dot{\imath}$, dat.)

Mk. iii, 5 .

Stupebant autem omnes, qui eum audiebant super prudentia et responsis ejus. ('̇ $\pi i$, dat.) Lk. ii, 47 .

Gentes autem super misericordia honorare Deum.... (vं $\pi^{\epsilon} \rho$, gen.)

Rom. xv, 9.

Attendite vobis super hominibus istis quid acturi sitis. ('́mi, dat.)

Acts $v, 35$.

Quia videbant signa, quae faciebat super his, qui infirmabantur. (émi, with gen.)

In Acts xv, 2 super is used to trans. $\pi \epsilon \rho i$ with gen.

Jn. vi, 2. 


\section{Super}

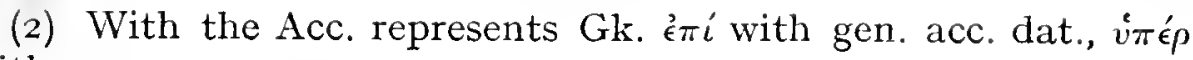
with acc.

Et duxerunt illum usque ad supercilium montis, super quem civitas illorum erat aedificata. ('́mí, gen.) Lk. iv, 29. Non est discipulus super magistrum, nec servus super dominum suum. (ír $\dot{\epsilon} \rho$, acc.)

Mt. $x, 24$.

Nonne duo passeres asse veneunt? et unus ex illis non cadet super terram sine Patre vestro. ('ं $\pi i$, acc.) Mt. $\mathrm{x}, 29$. In the sense of for, because of, where the Abl. would be expected. Quam cum vidisset Dominus, misericordia motus super ean. (émi, dat.)

Lk. vii, r3.

Nolite flere super me, sed super vos ipsas, et super filios vestros. ('́mí, acc.)

Lk. xxiii, 28.

Super is used after a comparative in Ps. xviii, II. 


\section{EXTRACTS FROM ECCLESIASTICAL WRITERS}

N.B. The numbers in the foot-notes refer to the sections in this book.

\section{Visiones Perpetuae.}

This is an extract from a unique document, namely the record of the imprisonment of a young Carthaginian matron Perpetua, written by herself. She was put to death in the persecution under Severus at the beginning of the third century. It is thought by some that these Acts were edited by Tertullian who refers to them in his treatise "De Anima."

Perpetua was arrested on the charge of being a Christian and cast into prison with four other catechumens. Her father, who was a pagan, did his best to persuade her to renounce Christ; but in vain. She was subsequently tried and condemned to the beasts and so suffered death with her companions.

The passages given below recount two visions which she saw in the prison.

The whole text of the Acts is given in one of the volumes of Hurter's series. A complete edition of all the Greek and Latin texts is published in "Texts and Studies," by J. A. Robinson, Cambridge.

Tunc dixit mihi frater mens: Domina soror, jam ${ }^{1}$ in magnā dignitate es; ${ }^{2}$ et tantā, ut postules visionem et ostendatur tibi, an passio sit, an ${ }^{3}$ commeatus. Et ego, quae me sciebam ${ }^{4}$ fabulari cum Domino, cujus beneficia ${ }^{5}$ tanta experta eram, fidenter repromisi ei dicens: Crastinā die tibi renuntiabo. Ft postulavi, et ostensum est mihi hoc: Video scalami auream ${ }^{6}$ mirae magnitudinjs ${ }^{7}$ pertingentem usque ad caelum, et ${ }^{8}$ ita angustam, per quam non nisi singuli ascendere possent: et in lateribus scalae omne genus ${ }^{9}$ ferramentorum infixum. Erant ibi gladii, lanceae, ${ }^{10}$ hami, machaerae, ut si quis negligenter, aut non sursum attendens ascenderet, 11 laniaretur, et carnes ejus inhaererent ferramentis. Et erat sub ipsā scalà draco cubans mirae magnitudinis, qui ascendentibus insidias parabat, et exterrebat ne ascenderent. Ascendit autem

1 in magnā dignitate es $=$ you are held in great honour.

2 et tantā, ut postules, I63. $\quad{ }^{3}$ commeatus $=$ release. vernacular word found in the comic poets. loving-kindnesses I had found to be so many." ${ }^{4}$ fabulari = to converse with, a 5 tanta, predicative, "whose 6 mirae magnitudinis, 26. "pertingentem = reaching to. ${ }^{8}$ et ita angustam, per quam, for "ita angustam, ut per eam," r63. " ferramentorum =iron instruments. ${ }^{10}$ hami, machaerae $=$ hooks and sabres ( $\mu a ́ \chi a<\rho a)$.

1 laniaretur $=$ he would be mangled. 


\section{Perpetua}

Saturus prior, et pervenit in caput scalae, et convertit se ad me, et dixit mihi: Perpetua, sustineo te: sed vide ne mordeat draco ille. Et dixi ego: Non ${ }^{1}$ me nocebit in nomine Domini Jesu Christi. Et ${ }^{2}$ de sub ipsā scalā quasi timens me, lente elevavit caput, et cum primum gradum ${ }^{3}$ calcassem, calcavi illius caput. Et ascendi, et vidi spatium horti immensum, et in medio horti sedentem hominem ${ }^{4}$ canum, in habitu pastoris, grandem, oves ${ }^{5}$ mulgentem : et circumstantes ${ }^{6}$ candidatos millia multa. Et levavit caput et adspexit me, et dixit mihi: ${ }^{7}$ Bene venisti, tegnon. Et clamavit me, et de ${ }^{8}$ caseo, quod mulgebat, dedit mihi quasi ${ }^{9}$ bucellum, et ego accepi junctis manibus et ${ }^{10}$ manducavi, et universi circumstantes dixerunt: Amen. Et ad sonitum vocis experrecta sum commanducans adhuc dulcis nescio quid. Et retuli statim fratri meo, et intelleximus passionem esse futuram, et coepimus nullam jam spem in ${ }^{11}$ saeculo habere.

Post dies paucos, dum universi oramus, subito mediā oratione profecta est mihi vox, et nominavi Dinocratem: et ${ }^{12}$ obstupui quod nunquam mihi in mentem venisset nisi tunc, et dolui commemorata casũs ejus. Et cognovi me statim dignam esse, et pro eo petere debere. Et coepi pro ipso orationem facere multam, et ingemiscere ad Dominum. ${ }^{13}$ Continuo ipsā nocte ostensum est hoc mihi in ${ }^{14}$ oromate. Video Dinocratem exeuntem de loco tenebroso, ubi et complures erant aestuantem et sitientem valde, ${ }^{15}$ sordido vultu, et colore pallido, et vulnus in facie ejus, quod, cum moreretur, habuit. Hic Dinocrates fuerat frater meus carnalis, annorum septem, ${ }^{16} \mathrm{qui}$ per infirmitatem facie canceratā male obiit, ita ut mors ejus ${ }^{17}$ odio fuerit omnibus hominibus. Pro hoc ego orationem feceram: et inter me et illum grande erat ${ }^{18}$ diastema, ita ut uterque ${ }^{19}$ ad invicem accedere non possemus. Erat deinde in ipso loco, ubi Dinocrates erat, ${ }^{20}$ piscina ${ }^{21}$ plena aquā, altiorem marginem habens quam erat

1 me. Many verbs which govern a dat. in Cl. L. do not always do so in Ecc. L., 37. $\quad{ }^{2}$ de sub (a double preposition) $=$ from below. $\quad{ }^{3}$ calcassem $=I$ had trodden on. ${ }^{4}$ canum = grey-haired. ${ }^{5}$ mulgentem $=$ milking. ${ }^{6}$ candidatos = white-robed . 8 caseo $=$ curd. $\quad$ ' bucellum $=$ a mouthful. $?$ Bene venisti, tegnon=Welcome, child $(\tau \epsilon \kappa \nu \circ \nu)$. nacular verb, common in the Vg.). $\quad{ }^{11}$ saeculo =this world, as of ten in Vg. 12 obstupui quod, I35, II2-II4. ${ }^{13}$ Continuo =straightway. ${ }^{14}$ oromate $=$ vision $(\dot{o} \rho \alpha ́ \omega) . \quad{ }^{15}$ sordido vultu = unclean appearance, 56 . firmitatem... =who died miserably through a cancer in the face. $\quad 17$ odio $=$ dis . gusting, 4I. $\quad{ }^{18}$ diastema $=a$ gulf $(\delta \iota \dot{a}, i \sigma \tau \eta \mu \iota)$. us could go to the other, 70. ${ }_{20}$ piscina $=a$ basin.

19 ad invicem $=$ neither of ${ }^{21}$ plena aquā, 49. 
statura pueri, et extendebat se Dinocrates quasi bibiturus. Ego dolebam quod et piscina illa aquam habebat, et tamen propter altitudinem marginis bibiturus non 'esset. Et experrecta sum et cognovi fratrem meum ${ }^{2}$ laborare. Sed confidebam profuturam orationem meam ${ }^{3}$ labori ejus, et orabam pro eo omnibus diebus quo usque transivimus in ${ }^{4}$ carcerem castrensem. ${ }^{5}$ Munere enim castrensi eramus ${ }^{6}$ pugnaturi. ${ }^{7}$ Natale tunc Getae Caesaris, et feci pro illo orationem die et nocte gemens et lacrimans, ut mihi ${ }^{8}$ donaretur. Die autem quo in ${ }^{9}$ nervo mansimus, ostensum est mihi hoc: Video locum illum, quem videram tenebrosum, esse lucidum: et Dinocratem mundo corpore, bene vestitum, ${ }^{10}$ refrigerantem. Et ubi erat vulnus, video ${ }^{11}$ cicatricem: et piscinam illam, quam retro videram, summisso margine usque ad ${ }^{12}$ umbilicum pueri : et aquam de eã trahebat sine cessatione, et super margine ${ }^{13}$ phiala erat plena aquã; et accessit Dinocrates, et de eā bibere coepit, quae phiala non deficiebat. Et satiatus abscessit de aquā ${ }^{14}$ ludere more infantium gaudens, et experrecta sum. Tunc intellexi translatum eum esse de poena.

Cyprian, Bishop of Carthage (martyred 258), was converted to Christianity in middle life. He was a famous rhetorician in his early days; but after his conversion he laid his secular studies aside and devoted himself entirely to Christian literature. In the treatises intended for the ordinary members of his flock he did not shrink from occasionally using the expressions and even the solecisms which are found in the Old Latin version of the Bible. His numerous quotations are naturally derived from the same source, and often differ both in wording and in reading from the Vulgate.

He, in common with other writers of the period, abandons the periodic style of Classical prose for short sentences with frequent antitheses and rhetorical questions.

The signs of his rhetorical training are everywhere manifest. In the matter of his treatises he freely copies Tertullian; but popu-

1 esset. This is subj. because it gives the thought of Perpetua, "he was not (as I thought) likely to drink." " aborare =to be in torment. 3 labori, 37. 4 carcerem castrensem $=$ the eamp prison. 5 Munere $=$ show. $\quad$ o pugnaturi, i.e. with the beasts. "Natale tunc Getae Caesaris, understand "erat." ${ }^{\circ}$ donaretur = that he might be given to me, i.e. that he might be saved. Compare Acts xxvii, 24, Et ecce donavit tibi Deus omnes qui navigant tecum. 9 nervo $=$ the stocks. $\quad 10$ refrigerantem $=$ refreshed or happy. This is the word generally used in the inscriptions in the Catacombs to express the state of the blessed departed. REFRIGERET TIBI DEUS ET CHRISTUS ET DOMINI NOSTRI ADEODATUS ET FELlX (from the cemetery of Commodilla). See Proverbs xxix,

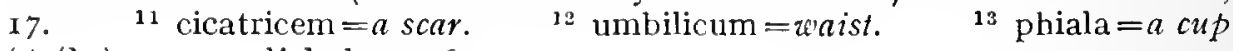
$(\phi \iota a ́ \lambda \eta) . \quad 14$ ludere, 162. 
larises and expands the materials that he borrows from him. In many respects, including the manner in which he uses quotations from Scripture, his treatises are curiously like some modern sermons. They are well worth the attention of the student on account of the simplicity of their style and their moral earnestness. The best modern edition of his works is in the Vienna Corpus by Hartel. Several of his treatises and a selection of letters are published in Hurter's SS. Patrum Opuscula Selecta.

Jerome excellently sums up the characteristics of Tertullian and Cyprian in his epistle to Paulinus:

Tertullianus creber est in sententiis; sed difficilis in loquendo. Beatus Cyprianus, instar fontis purissimi, dulcis incedit et placidus: et cum totus sit in exercitatione virtutum, occupatus persecutionum angustiis, de Scripturis divinis nequaquam disseruit.

\section{Jesus Christus Patientiae Exemplar.}

Atque ut plenius intelligere possimus, fratres dilectissimi, ${ }^{1}$ quia patientia Dei 'res est, et quisquis lenis et patiens et mitis est Dei Patris imitator est, Dominus ipse dixit in Evangelio suo: "Audistis quia dictum est: ${ }^{3}$ Diliges proximum tum et ${ }^{4}$ odio habebis inimicum tuum. Ego autem dico vobis: Diligite inimicos vestros, et orate pro eis, qui vos persequuntur, ut sitis filii Patris vestri, qui in caelis est, qui solem suum oriri facit super bonos et malos, et pluit super justos et injustos. Si enim dilexeritis eos qui vos diligunt, quam mercedem habebitis? Nonne sic et Publicani faciunt? Ft si salutaveritis fratres vestros tantum, quid amplius facitis? Nonne et ethnici ${ }^{5}$ idipsum faciunt? ${ }^{3}$ Eritis itaque vos perfecti, ${ }^{6}$ quomodo Pater vester caelestis perfectus est."

Sic perfectos dixit fieri Dei filios si patientia Dei Patris 7 maneat in nobis. Nec hoc, fratres dilectissimi, Jesus Christus Dominus et Deus noster tantum verbis docuit sed implevit et factis. Et qui ad hoc descendisse se dixerat ut voluntatem Patris faceret, inter cetera mirabilia ${ }^{8}$ virtutum suarum quibus indicia divinae majestatis expressit paternam quoque patientiam servavit. Omnes denique actīs ejus áb ipso statim adventı patientiā signantur, quod primum de illā sublimitate coelesti ad terrena descendens non aspernatur Dei Filius carnem hominis induere, et ${ }^{9} \mathrm{cum}$ peccator ipse non esset, aliena peccata portare.

1 Quia. Observe the use of this barbarous construction even in Cyprian.

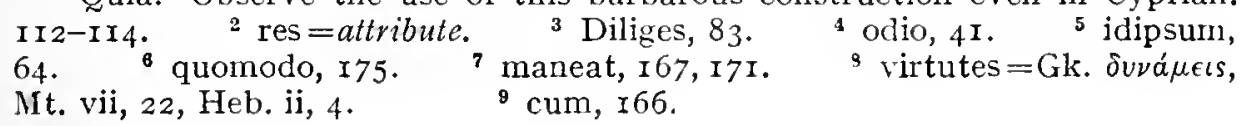


Immortalitate interim positā, fieri se et mortalem patitur, ut ${ }_{1}$ innocens pro nocentium salute perimatur. Dominus baptizatur a servo, et ${ }^{2}$ remissam peccatorum daturus, ipse non dedignatur ${ }^{3}$ lavacro regenerationis corpus abluere. ${ }^{4}$ Diebus quadraginta jejunat, per quem ceteri ${ }^{5}$ saginantur: esurit et famem sentit, ut qui in ${ }^{6}$ fame sermonis et gratiae fuerant, coelesti pane saturentur. Discipulis non ut servis dominicā potestate praefuit, sed benignus et mitis fraternā eos caritate dilexit, dignatus etiam pedes apostolorım lavare, ut cum circa servos talis ${ }^{7}$ est dominus, exemplo suo doceret, qualis circa compares et aequales debeat esse conservus. Sub ipsā autem passione et cruce, priusquam ad crudelitatem necis ${ }^{8}$ veniret, quae contumeliarum toleravit ludibria. Coronatur spinis, qui martyres floribus coronat aeternis: palmis in faciem verberatur qui palmas veras vincentibus tribuit. Ille innocens, ille justus, immo innocentia ipsa et ipsa justitia, inter facinorosos ${ }^{9}$ deputatur, et testimoniis falsis veritas premitur, judicatur judicaturus, et Dei Sermo ${ }^{10}$ ad victimam tacens ducitur. Et cum ${ }^{10}$ ad crucem Domini confundantur sidera, elementa turbentur, ille non loquitur, nec movetur. Usque ad finem perseveranter toleratur omnia, ut consummetur in Christo plena et perfecta patientia. Et post ista omnia adhuc interfectores suos, si conversi ad eum veniunt, suscipit; et ${ }^{11}$ patientiā salutari ad conservandum benignus et patiens Ecclesiam suam nemini claudit. Illos adversarios, illos blasphemos, illos nominis sui semper inimicos, si paenitentiam delicti agunt, si admissum facinus agnoscant, non solum ad indulgentiam ${ }^{12}$ criminis, sed et ad praemium ${ }^{13}$ regni coelestis admittit. Quid potest patientius, quid benignius dici? Vivificatur Christi sanguine etiam qui fudit sanguinem Christi. Talis est Christi et tanta patientia; quae nisi talis ac tanta existeret, Paulum quoque apostolum Ecclesia non haberet.

Quod si et nos in Christo sumus, si ipsum induimus, si ipse est salutis nostrae via, qui Christum vestigiis salutaribus sequimur, per Christi exemplum gradiemur, sicut Johannes apostolus instruit dicens: "Qui dicit se in Christo manere, debet ${ }^{14}$ quomodo ille ambulavit et ipse ambulare."

1 innocens, 200. $\quad 2$ remissam $=$ remissionem. $\quad 3$ lavacro, Titus iii, 5 . 4 Diebus, 55. ${ }^{5}$ saginare. In the $\mathrm{Cl}$. this means to stuff; like many other words it has in Ecc. L. a more refined meaning =fill. ${ }^{6}$ Amos viii, I 1. ' est A very unusual Indicative in a clause of Cause, I 56. ${ }^{8}$ veniret, I54. deputatur $=$ is reckoned, Lk. xxii, 37. ${ }^{10}$ ad, $216 .{ }^{11}$ patientiā salutari, with patience conducive to salvation. $\quad{ }^{12}$ criminis, $24 . \quad{ }^{13}$ regni, 26. ${ }^{14}$ quomodo, $\mathbf{7} 75$. 


\section{Cyprian}

Item Petrus, super quem Ecclesia Domini dignatione fundata est, in epistolā suā ponit et dícit: "Christus passus est pro nobis, relinquens vobis exemplum ut sequamini vestigia ejus: qui peccatum non fecit, nec dolus inventus est in ore ejus, qui cum malediceretur non remaledicebat, cum pateretur non minebatur, tradebat autem se judicanti se 'injuste."

De bono patientiae (adapted).

\section{Quid est voluntas Dei?}

Voluntas autem Dei est ${ }^{2}$ quam Christus et fecit et docuit. Humilitas in ${ }^{3}$ conversatione, stabilitas in fide, ${ }^{4}$ verecundia in verbis, in factis justitia, in operibus misericordia, in moribus disciplina, injuriam facere non nosse et factam posse tolerare, cum fratribus pacem tenere, Deum toto corde diligere, amare in illo ${ }^{5}$ quod Pater est, timere quod Deus est, Christo nihil omnino praeponere, quia nec nobis quidquam ille praeposuit, caritati ejus inseparabiliter adhaerere, cruci ejus fortiter ac fidenter ${ }^{6}$ assistere quando de ejus nomine et honore certamen est, exhibere in sermone constantiam quā confitemus, in quaestione fiduciam quā ${ }^{7}$ congredimur, in morte patientiam quā coronamur. Hoc est coheredem Christi esse velle, hoc est praeceptum Dei facere, hoc est voluntatem Patris adimplere.

De Oratione Dominica.

Notice the use of the infinitive as a verbal noun parallel with other nouns.

\section{Quare justus cum Christo esse desiderat.}

Scriptum est enim, justum fide vivere. Si justus es, et fide vivis, si vere in Christum credis, cur non cum Christo futurus et de Domini p:omisso ${ }^{8}$ securus, ${ }^{9}$ quod ad Christum voceris, amplecteris et quod diabolo careas, gratularis? Simeon denique ille justus, qui vere justus fuit, qui fide plenā Dei praecepta servavit, cum ei divinitus responsum fuisset, ${ }^{10}$ quod non ante moreretur, quam Christum vidisset, agnovit in spiritı natum esse jam Christum, de quo sibi

1 This reading differs from that of the received Gk. texts. 2 quam $=$ the will which. ${ }_{3}^{3}$ conversatione, à $\nu \sigma \sigma \rho \circ \phi \dot{\eta}=$ manner of life, Gal. i, $13 . \quad 4$ verecundia = modesty. $\quad{ }^{5}$ quod Pater est = the fact that he is Father. ${ }^{6}$ assistere, to stand by. " congredimur $=$ we agree together. ${ }_{8}^{8}$ securus $=$ free from care, cf. Mt. xxviii, I4. ${ }^{9}$ quod ad Christum...=why do you not welcome the fact that you are being called to Christ, and rejoice that you are being freed from the devil?

10 quod non ante moreretur, Ir2-II4. 
fuerat ante praedicatum; quo viso, scivit se cito esse moriturum. Laetus itaque de morte jam proximā, et de vicinā $\mathbf{1}$ accersitione securus, accepit in manus puerum, et benedicens Dominum exclamavit et dixit: "Nunc dimittis servum tuum, Domine, secundum verbum tuum in pace, quoniam viderunt oculi mei ${ }^{2}$ salutare tuum." Probans scilicet atque contestans tunc esse servis Dei pacem, tunc liberam, tunc tranquillam quietatem, quando de istis mundi turbinibus extracti, ${ }^{3}$ sedis et securitatis aeternae portum petimus, quando, ${ }^{4}$ expunctā hac morte, ad immortalitatem venimus. Illa est enim vera pax, illa fida tranquillitas, illa stabilis et firma et perpetua securitas.

De Mortalitate.

\section{DE DEFECTU F1DEI IN TRIBULATIONE.}

Hoc autem fit, fratres dilectissimi, quia fides deest, quia nemo credit vera esse, quae promittit Deus, qui ${ }^{5}$ verax est, cujus sermo credentibus aeternus et firmus est.

Si tibi vir gravis et laudabilis aliquid polliceretur, haberes ${ }^{6}$ utique pollicenti fidem, nec te falli aut decipi ab eo crederes, quem stare in sermonibus atque in actibus suis scires. Nunc Deum tecum loquitur; et tu mente incredulā perfidus fluctuas? Deus tibi de hoc mundo recedenti immortalitatem atque aeternitatem pollicetur, et tu dubitas? Hoc est Deum omnino non nosse: hoc est Christum credentium dominum et magistrum peccato incredulitatis offendere: hoc est in ecclesiā constitutam fidem in domo fidei non habere. Quantum prosit exire de saeculo Christus ipse salutis atque utilitatis nostrae magister ostendit, qui, cum discipuli ejus contristarentur quod dixit se jam recessurum, locutus est ad eos dicens, "Si me dilexistis, "gauderetis utique, quoniam vado ad Patrem": docens scilicet et ostendens, cum cari, quos diligimus, de saeculo exeunt, ${ }^{8}$ gaudendum potius quam dolendum. Cujus rei memor beatus apostolus Paulus in epistolā suā ponit atque dicit: " "Mihi vivere Christus est, et mori lucrum": lucrum maximum computans jam saeculi ${ }^{10}$ laqueis non teneri, jam nullis peccatis et vitiis carnis ${ }^{11}$ obnoxium fieri, exemptum

1 accersitione=summons. This word is often used in the inscriptions on graves. $\quad 2$ salutare $=$ Gk. $\sigma \omega \tau \eta \dot{p} p$ ov, salvation, often used in the Psalms, cf. xii, 6. $\quad{ }^{3}$ sedis =home. $\quad{ }^{4}$ expunctā hac morte=after this death has been destroyed. ${ }^{5}$ verax $=$ true, Rom. iii, $4 .{ }^{6}$ utique =certainly. ${ }^{7}$ gauderetis, I67, I7I. ${ }^{8}$ gaudendum, I92. ${ }^{9}$ Nlihi vivere..., I I7. ${ }^{10}$ laqueum $=$ snare. 11 obnoxium $=$ exposed to. 


\section{Cyprian}

${ }^{1}$ pressuris angentibus, et ${ }^{2}$ venenatis diaboli faucibus liberatum ad laetitiam salutis aeternae Christo vocante proficisci.

At enim quosdam movet, quod aequaliter cum gentibus nostros morbi istius ${ }^{3}$ valetudo corripiat; quasi ad hoc ${ }^{4}$ crediderit Christianus, ut immunis a contactu malorum, mundo et saeculo feliciter perfruatur, et non omnia hic adversa perpessus ad futuram laetitiam reservetur. Movet quosdam quod sit nobis cum ceteris ${ }^{5}$ mortalitas ista communis, quid enim nobis in hoc mundo non communis cum ceteris, quamdiu adhuc secundum legem primae nativitatis manet caro iste communis? ${ }^{6}$ Quoadusque istic in mundo sumus, cum genere humano carnis aequalitate conjungimur, spiritu ${ }^{7}$ separamur. Itaque donec corruptivum istud induat incorruptionem, et mortale hoc accipiat immortalitatem, et Christus nos perducat ad Deum Patrem, quaecumque sunt carnis incommoda, sunt nobis cum humano genere communia. Sic cum fetu sterili terra jejuna est, neminem fames ${ }^{7}$ separat. Sic cum irruptione hostili civitas aliqua possessa est, omnes simul captivitas vastat. ${ }^{8} \mathrm{Et}$ quando imbrem nubila serena suspendunt, omnibus ${ }^{9}$ siccitas una est. Et cum navem ${ }^{10}$ scopulosa saxa ${ }^{11}$ constringunt, navigantibus ${ }^{12}$ naufragium sine exceptione commune est. Et oculorum dolor et impetus febrium et omnium valetudo membrorum cum ceteris communis est nobis, quamdiu portatur in saeculo caro ista communis.

De Mortalitate.

\section{Quod filit Dei Patri similes esse debent.}

Si hominibus laetum est et gloriosum filios ${ }^{13}$ habere consimiles, et tunc magis ${ }^{13}$ generasse delectat, si ad patrem lineamentis paribus ${ }^{14}$ suboles subseciva respondeat, quanto major in Deo Patre laetitia est cum ${ }^{15}$ quis sic spiritualiter nascitur, ut in actibus ejus et laudibus divina generositas praedicetur? Quae justitiae palma est, quae corona, esse se talem de quo Deus non ${ }^{16}$ dicat "Filios generavi et exaltavi, ipsi autem spreverunt me." ${ }^{17 C}$ Collaudet te potius Christus

1 pressuris angentibus = agonising trials. jares. 3 valetudo $=$ weakness.

2 venenatis faucibus = poisoned =morta

- Quoadusque = so long as. 4 crediderit, $r 75$. set apart. keeps off the showers. disease. 11 constringunt $=$ crush. I 7 . ${ }_{14}$ suboles subseciva = surviving offspring. except after 'si,' cf. Jas. v, I4, 69a.

\section{${ }^{9}$ siccitas $=d r o u g h t$.}

12 naufragium = shipwreck. 16 dicat, $150(\mathrm{I})$.
5 mortalitas 7 separare $=$ to ${ }^{10}$ scopulosa $=$ precipitous . 13 habere, generasse, 15 quis. Rare in $\mathrm{Cl}$. 17 Collaudet, ror. 
et invitet ad praemium dicens: "Venite, benedicti Patris mei, percipite regnum quod vobis paratum est ab origine mundi." His meditationibus corroborandus est animus, ${ }^{1}$ ejusmodi exercitationibus contra omnia diaboli jacula firmandus. Sit in manibus divina lectio. Oratio ${ }^{2}$ jugis ${ }^{3}$ omnino non cesset. Spiritualibus semper actibus occupemur, ut quotiescunque inimicus ${ }^{4}$ accesserit, et clausum adversum se pectus inveniat et armatum. ${ }^{\mathbf{5}}$ Non enim Christiani hominis corona est una, quae temporibus persecutionis accipitur. Habet et pax coronas suas, quibus ${ }^{6}$ de variā et multiplici ${ }^{7}$ congressione victores, prostrato et subacto adversario, coronantur. Libidinem subegisse continentiae corona est. Contra iram, contra injuriam repugnasse corona patientiae est. De avaritiā triumphus est pecuniam spernere. Laus est fidei fiduciā futurorum mundi adversa tolerare. Et qui superbus in prosperis non est, gloriam de humilitate consequitur. In hoc virtutum ${ }^{8}$ stadio quotidie currimus, ad has justitiae palmas et coronas sine intermissione temporis pervenimus. Cogitemus ergo caeleste regnum. Cogitemus quod filii Dei hi soli possint vocari, qui nativitate caelesti et lege divinā ad similitudinem Dei Patris et Christi ${ }^{\mathbf{9}}$ respondeant adunati. Cogitemus sub oculis Dei nos stare, spectante et judicante ipso conversationis ac vitae nostrae curricula decurrere, pervenire nos tunc demum posse ${ }^{10} \mathrm{ut}$ eum videre contingat, si ipsum nunc videntem delectemus actibus nostris, si nos dignos gratiā ejus et indılgentiā praebeamus, si placitıri semper in regno, in hoc mundo ante placeamus.

De zelo et livore (adapted).

Ambrose (died 397), the famous Bishop of Milan, was the son of the prefect of Gaul, and was educated with a view to his occupying a high administrative position in the state.

When still a young man lie was made prefect of Liguria and Aemilia and, as such, was called upon to preside at the election of a bishop for Milan after the death of the Arian bishop Auxentius. His reputation among the people was such that, although he was a layman and unbaptized, he was himself elected bishop by popular acclamation much against his wish.

He disposed of his property and set himself to learn, in order

1 ejusmodi $=$ such, 7r. $\quad{ }^{2}$ jugis $=$ continuous. $\quad{ }^{3}$ omnino non cesset, 100. ${ }^{4}$ accesserit, 88. ${ }^{5}$ Non enim... accipitur $=$ For the crown which is received in time of persecution is not the only crown that a Christian man can win. ${ }^{6}$ de, 2 II. ${ }^{7}$ congressione $=$ contest. ${ }^{8}$ stadio $=$ racecourse. ${ }^{9}$ respondeant, I50. $\quad{ }^{10}$ ut...contingat, a clause of consequence, 163 . 


\section{Ambrose}

that he might be able to teach the doctrines of Christianity. He became the most powerful champion of the Catholic party in the West against the Arians, and in the end secured the complete triumph of the Catholic doctrine in spite of much opposition and persecution. He also urged the Emperors Gratian, Valentinian and Theodosius to sweep away the last remains of paganism, to refuse the title of Pontifex Maximus, and to remove the altar of Victory from the Senate House. In the troubled times during which the young Emperors Gratian and Valentinian perished he was the most influential statesman in the West as well as the greatest bishop.

$\mathrm{He}$ is also famous as being the teacher who brought Augustine back to the Catholic faith, for his courage in making Theodosius do penance for the massacre of Thessalonica, and as being the founder of Latin Hymnology.

$\mathrm{He}$ has left many sermons and treatises written with a vigour and directness worthy of a Roman magistrate.

$\mathrm{He}$ was not an original thinker: his method of expounding Scripture was the allegorical method of Philo and Origen, and he copied Cicero in his ethical treatises.

$\mathrm{He}$ is nevertheless one of the greatest figures in the history of the Church, and in his capacity as a teacher and organiser sums up in himself the distinguishing characteristics of the Roman people.

Some of his works such as the De fide are published in Hurter's collection.

Ambrose in this piece imagines the pleas that the heretics will be constrained to make before the judgment seat of Christ. He is addressing the heretics throughout, and their appeals and the replies of Christ are in dialogue form. The heretics speak in the first person as well as Ambrose. Care must be taken to distinguish the speakers.

\section{De judicio Domini in ARianos et allos haEREticos.}

Igitur ${ }^{1}$ prosecutionem tuam videamus quemadmodum concilies tibi judicem. Dic, sane, dic, inquam: Ego te, Christe, puto esse dissimilem Patri. Respondebit et ille: Discerne, si potes: discerne, inquam, in quo putes me esse dissimilem.

Dic aliud: Creaturam, inquies, te arbitror. Respondebit et Christus: Si duorum hominum testimonium verum est, tu nec mihi nec Patri saltem credere debuisti, qui genitum nominavit?

Bonum, inquies, nego. Dicet et ille: Fiat tibi secundum fidem tuan, ut tibi bonus non sim.

\footnotetext{
${ }^{1}$ prosecutionem $=$ pleading.
} 
Omnipotentem non arbitror. Respondebit et ipse: Non possum ergo tibi tua peccata ${ }^{1}$ donare.

2Subjectum dico. Referet ad hoc: Cur igitur libertatem ac veniam petis ab eo, quem putas pro servitio esse subjectum?

Video haerere prosecutionem tuam: non urgeo, quia peccatorum meorum ipse sum conscius. Non invideo veniam, quia ipse opto indulgentiam: votum tuum scire desidero. En allego apud judicem desideria tua; non prodo crimina, seriem tuorum expecto votorum.

Dic itaque ea ${ }^{3}$ quae in communi voto sunt; dic, inquam: Domine, fac me ad imaginem Dei. Respondebit ille: Ad quem imaginem? Quam negasti? Dic: Fac me incorruptibilem. Referet utique: Quomodo te incorruptibilem facere possum, quem tu creaturam ${ }^{4}$ dicendo, capacem corruptibilitatis esse voluisti? Mortui resurgent incorrupti, et tu corruptibilem dicis, quem Deum cernis?

Dic: Bonus esto mihi. Dicet tibi: Quid postulas quod negasti? Ego te bonum esse volui, ego dixi: Estote sancti, quoniam ipse sanctus sum; et tu mihi id negare contendis? Et tu expectas veniam peccatorum? Sed nemo potest donare peccata nisi solus Deus. Itaque cum verus et solus tibi Deus non sim, non possum utique tua peccata donare.

Haec Arianus dicat et Photinianus: Nego te, inquit, Deum.

Respondebit ei Dominus: Dixit insipiens in corde suo: Non est Deus. De quo dictum putas, de Judaeo, de Gentili, an de diabolo?

De quovis dictum sit, Photiniane, tolerabilior est ille, qui tacuit: tu vero et voce ausus es dicere, ut insipiente insipientior probareris.

Negas ergo, inquit, Deum, cum ego dixerim: ${ }^{5}$ Dii estis, et filii Excelsi omnes. Et tu Deum negas, cujus opera divina circumspicis?

Dicat et Sabellianus: Ego te ipsum Patrem et Filium et Spiritum Sanctum arbitror. Respondebit et Dominus: Non audis Patrem, non audis Filium. Numquid hic ulla confusio est? Scriptura ipsa te docet Patrem esse, qui detılit judicium: Filium esse, qui judicat. Non audisti me ${ }^{6}$ dicentem: Solus non sum; sed ego et qui misit me Pater?

Dicat et Manichaeus: Ego auctorem carnis nostrae diabolum credo. Respondebit ei: Ergo quid facies in caelestibus? Vade ad

${ }^{1}$ donare $=$ to forgive, Eph. iv, 32 .

2 Subjectum dico $=I$ say that thou art under authority. " dicendo I 88 . ${ }^{3}$ quae...sunt $=$ the things that men most commonly desire. 5 In John $x, 34$; Ps. xxxii, 6.

6 dicentem, I 38 . 


\section{Jerome}

auctorem tuum. Ego eos volo mecum esse, quos dedit mihi Pater. $\mathrm{Tu}$ te a diabolo creatum, Manichaee, arbitraris: ad illius ergo festina sedem, ubi ignis et sulphur, ubi non restinguitur ejus incendium, ne unquam poena moriatur.

${ }^{1}$ Mitto alia haereticorum portenta non nomina; quid eis erit judicii, quae erit forma sententiae? Respondebit his omnibus et ille moraliter: Populus meus, quid feci tibi, aut quid contristavi te? Nonne ex Aegypto eduxi te, et ex domo servitutis liberavi te?

Sed parum est ex Aegypto liberasse, et ex domo servitutis eripuisse: plus est te ipsum dedisse pro nobis. Dices ergo: Nonne vestras omnes suscepi injurias? Nonne corpus meum pro vobis obtuli? Nonne mortem appetivi, quod non erat ${ }^{2}$ Divinitatis meae, sed vestrae redemptionis? Haeccine referuntur gratiae? Hoc profecit sanguis meus, sicut in propheta jan dixi: Quae utilitas in sanguine meo, quia descendi in corruptionem? Hoc ergo profecit, ut me impie negaretis, pro quibus ista sustinui.

Ego vero tunc, Domine Jesu, etsi gravium peccatorum mihi ipse sim conscius, dicam tamen: Non te negavi; habes quod 3ignoscas fragilitati carnis. Delictum fateor, peccatum non abnuo: si vis, potes me mundare. Ne, quaeso, in judicium ${ }^{4}$ intres cum servo tuo. Non quaero ut judices, sed ut ignoscas.

De fide, II, I3.

Jerome (died 420) was the greatest linguistic scholar among the Fathers. In early life he was educated in Rome by Donatus, and was well acquainted with Greek. He studied Hebrew with a Jew to enable him to make a new translation of the O.T. from the original.

In addition to his version of the Bible he wrote many commentaries and letters and made translations from the works of Origen. In his original writings his style is good and clear, but in his translation of the Bible he sacrificed the Latin language to his desire to make a literal version.

Even in his original writings he was no purist either in construction or vocabulary, and never shrunk from using many words, especially abstract nouns, compound nouns and diminutives,

Which would have made Quintilian stare and gasp.

He also frequently coined new words if the nature of the subject which he was treating demanded them.

1 Mitto alia... =I pass over the other nameless heretical monsters. 2 Divinitatis, 27. ${ }^{4} \mathrm{Ne}$ intres, 99. 
The influence of his writings on later Latin and the languages derived from it was very great.

In spite of the dream described in the next selection he never could get rid of his love for the Latin classics, for which he considered an elaborate apology necessary (see Ep. 70).

It should be remembered that he was of a vehement nature and that for the greater part of his life he lived as a hermit or a studious recluse in Syria or Palestine.

The best edition of his works is by Vallarsi, Verona I734-42. It is carelessly reprinted in Migne, Pat. Lat.

There is a small selection of his letters in Hurter, and an edition of them is being published in the Vienna Corpus.

An elaborate account of his style, excluding the Vulgate, is given in Goelzer, La Latinité de St Jérôme. Hachette, Paris.

\section{Sominium Hieronymi.}

Cum ante annos plurimos domo, parentibus, sorore, cognatis, et quod his difficilius erat, consuetudine ${ }^{1}$ lautioris cibi propter caelorum me regna ${ }^{2}$ castrassem: et Hierosolymam ${ }^{3}$ militaturus pergerem, ${ }^{4}$ bibliotheca, quam mihi Romae summo studio et labore confeceram, carere omnino non poteram: itaque miser ego, lecturus Tullium, jejunabam, post noctium crebras vigilias, post lacrymas, quas mihi praeteritorum recordatio peccatorum ex imis ${ }^{5}$ visceribus eruebat, Plautus sumebatur in manus.

Si quando in memetipsum reversus, prophetas legere coepissem, ${ }^{6}$ sermo horrebat incultus: et quia lumen caecis oculis non videbam, non oculorum putabam culpam esse, sed solis.

Dum ita me antiquus serpens illuderet, in mediã ferme quadragesimā medullis infusa febris corpus invasit exhaustum, et sine ullā requie, quod ${ }^{7}$ dictu quoque incredibile est, sic infelicia membra ${ }^{8}$ depasta est, ut ossibus vix haererem. Interim parantur exsequiae, et vitalis animae calor, toto frigescente jam corpore, in solo tantum tepente ${ }^{9}$ petusculo palpitabat; cum subito raptus in spiritu, ad

${ }^{1}$ lautioris cibi $=$ sometwhat delicate food, a $\mathrm{Cl}$. use of the comparative. ${ }^{2}$ castrassem $=I$ had deprived myself. $\quad{ }^{3}$ militaturus = to join the army of the Church, i.e. to become a monk. Jerome often speaks of the monastic life in terms of military service. "visceribus = heart. ${ }^{\circ}$ sermo horrebat incultus $=1$ terally, their uncultivated style bristled, i.6. repelled me. ${ }_{7}^{7}$ dictu, 193. ${ }_{8}^{8}$ depasta from depascor. See Verg. Ec. i, 54, and Ps. ci, 5, and notice the mixture of literary reminiscences. $\quad{ }^{9}$ petusculo, diminutive from pectus. The use of diminutives is characteristic of Late Latin. 


\section{Jerome}

tribunal judicis pertrahor; ubi tantum luminis, et tantum erat ex circumstantium claritate fulgoris, ut projectus in terram, sursum aspicere non auderem.

Interrogatus de conditione, Christianum me esse respondi. Et ille, qui praesidebat, Mentiris, ait; Ciceronianus es, non Christianus: ubi enim thesaurus tuus, ibi et cor tuum.

Illico obmutui, et inter verbera (nam caedi me jusserat) conscientiae magis igne torquebar illum mecum ${ }^{\mathbf{1}}$ versiculum reputans: In inferno autem quis confitebitur tibi? Clamare autem coepi et ejulans dicere: Miserere ${ }^{2}$ mei, Domine, miserere mei. Haec vox inter flagella resonebat.

Tandem ad praesidentis genua ${ }^{3}$ provoluti qui adstabant, precebantur ut veniam tribueret adulescentiae, et errori locum paenitentiae ${ }^{4}$ commodaret, ${ }^{5}$ exacturus deinde cruciatum, si gentilium literarum libros aliquando legissem. Ego qui in tanto constrictus ${ }^{6}$ articulo, ${ }^{7}$ vellem etiam majora promittere, jurare coepi, et nomen ejus obtestans dicere: Domine,"si unquam habuero codices seculares, si legero, te negavi. In haec ${ }^{8}$ sacramenti verba dimissus, revertor ad superos, et mirantibus cunctis oculos aperio, tanto lacrymarum imbre perfusos, ut etiam incredulis fidem facerem ex dolore. Nec vero sopor ille fuerat, aut vana somnia, quibus saepe deludimur; testis est tribunal illud, ante quod jacui: testis judicium triste, quod timui: ita mihi nunquam contingat in talem incidere quaestionem. ${ }^{9}$ Liventes fateor habuisse me ${ }^{10}$ scapulas, plagas sensisse post somnum, et tanto dehinc studio divina legisse, quanto non ante mortalia legeram.

Ep. $x x 11,30$.

See the comment on this dream in Milton, Areopagitica, p. I8, in Temple Classics Edition.

\section{DE VITA CLERICORUM.}

Igitur clericus, qui Christi servit ecclesiae interpretetur primum ${ }^{11}$ vocabulum suum, et nominis definitione ${ }^{12}$ prolată, nitatur esse quod dicitur. Si enim $\kappa \lambda \hat{\eta} \rho \circ$ Sraece, "sors" Latine appellatur, propterea vocantur clerici, vel quia de sorte sunt Domini, vel quia

1 See p. I26, n. 9. 2 mei, 29.

3 ad genua provoluti. A regular literary phrase, Livy, xxxiv, II. $\quad{ }^{4}$ commodaret $=$ grant. $\quad{ }^{5}$ exacturus $=$ and that he should exact. $\quad$ articulo $=$ literally, a joint, hence $a$ point, trans. a critical condition. ${ }^{7}$ vellem, potential subj., ro3. in its $\mathrm{Cl}$. sense of an oath. ${ }_{9}^{9}$ Liventes =black with blows. shoulders. $\quad 11$ vocabilum =title. $\quad 12$ prolatā=made known. 
ipse Dominus sors, id est, pars clericorum est. Qui autem vel ipse pars Domini est, vel Dominum partem habet talem se exhibere debet, ut et ipse possideat Dominum, et possideatur a Domino.

Qui Dominum possidet, et cum prophetā dicit: Pars mea Domimus, nihil extra Dominum habere potest: quod si quidpiam aliud habuerit praeter Dominum, pars ejus non erit Dominus. ${ }^{1}$ Verbi gratiā: si aurum, si argentum, si possessiones, si variam ${ }^{2}$ supellectilem, cum istis partibus Dominus pars ejus fieri non dignabitur. Si autem ego pars Domini sum, habens victum et vestitum, his contentus ero, et nudam crucem nudus sequar.

${ }^{3}$ Mensulam tuam pauperes et peregrini et cum illis Christus conviva ${ }^{4}$ noverit. ${ }^{5}$ Negotiatorem clericum, et ex inope divitem, ex ignobili gloriosum, quasi quandam pestem fuge. Corrumpunt mores bonos confabulationes pessimae.

* * * * * * * * * *

Divinas Scripturas saepins lege, imo nunquam de manibus tuis sacra lectio deponatur. ${ }^{6}$ Disce quod doceas: obtine eum qui secundum doctrinam est fidelem sermonem, ut possis exhortari in doctrinā sanā, et contradicentes revincere. Non confundant opera tua sermonem tuum: ne, cum in ecclesiā loqueris, tacitus quilibet respondeat: Cur ergo haec, quae dicis, ipse non facis?

${ }^{7}$ Hospitiolum tuum aut raro aut nunquam mulierum pedes terant. Omnes puellas et virgines Christi aut aequaliter ignora, aut aequaliter dilige. Si propter officium clericatūs aut vidua a te visitatur, aut virgo, nunquam domum solus ${ }^{8}$ introeas. Solus cum solā, secreto et absque arbitro vel teste ${ }^{8}$ non sedeas. Si familiarius est aliquid loquendum: habet nutricem majorem domus, virginem, viduam, vel maritam: non est tam ${ }^{9}$ inhumana ut nullum praeter te habeat, cui se audeat credere. Caveto omnes suspiciones, et quidquid probabiliter fingi potest, ne fingatur ante devita. Crebra munuscula, et ${ }^{10}$ sudariola, et ${ }^{11}$ fasciolas, et vestes ori applicatas, et oblatos ac ${ }^{12}$ degustatos cibos, blandas et dulces

1 Verbi gratiā =for example. $\quad{ }^{2}$ supellectilem =furniture. $\quad{ }^{3}$ Mensulam, diminutive of mensa. clergyman in business. ${ }^{7}$ Hospitiolum $=$ home. 4 noverit, 89.

5 Negotiatorem clericum $=a$

- Disce quod doceas=lcam that you may teach, r59. 8 nunquam introeas...non sedeas, $99 . \quad{ }^{9}$ inhumana =cut off from human socicty. ${ }^{10}$ sudariola = napkins. =garters. $\quad 12$ degustatos $=$ slightly tastcd. 


\section{Jerome}

litterulas sanctus amor non habet. "Mel meum, lumen meum, meum desiderium." Omnes delicias et 1lepores et risu dignas ${ }^{2}$ urbanitates et caeteras ineptias amatorum in comoediis erubescimus, in sacculi hominibus detestamur: quanto magis in monachis et clericis, quorum et sacerdotium ${ }^{3}$ proposito, et propositum ornatur sacerdotio? Non hoc dico, quod aut in te, aut in sanctis viris ista ${ }^{4}$ formidem: sed quod in omni proposito, in omni gradu et sexu et boni et mali reperiuntur, malorumque condemnatio laus bonorum ${ }^{4}$ sit.

* $\quad * \quad * \quad * \quad * \quad * \quad *$

Docente te in ecclesiā, non clamor populi, sed gemitus suscitetur : lacrymae auditorum laudes tuae sint: sermo presbyteri scripturarum lectione conditus sit. Nolo te declamatorem esse, et ${ }^{5}$ rabulam garrulumque sine ratione, sed mysteriorum peritum, et sacramentorum Dei tui eruditissimum. Verba volvere, et celeritate dicendi apud imperitum vulgus admirationem sui facere, ${ }^{6}$ indoctorum hominum est. Nihil tam facile, quam ${ }^{7}$ vilem plebiculam et indoctam ${ }^{8}$ concionem linguae volubilitate decipere, quae quidquid non intelligit, plus miratur.

* $\quad * \quad * \quad * \quad * \quad * \quad * \quad *$

Vestes ${ }^{9}$ pullas aeque devita, ut candidas. Ornatūs ut ${ }^{10}$ sordes pari modo fugiendae sunt: quia alterum delicias, alterum ${ }^{11}$ gloriam redolet. Non ${ }^{12}$ absque amictu lineo incedere, sed pretium vestium linearum non habere laudabile est: alioquin ridiculum et plenum dedecoris est, referto ${ }^{13}$ marsupio, quod sudarium ${ }^{14}$ orariumque non habeas ${ }^{15}$ gloriari. Sunt, qui pauperibus paulum tribuunt, ut amplius accipiant, et sub praetextu ${ }^{16}$ eleemosynae quaerunt divitias, quae magis venatio appellanda est, quam eleemosynae genus. Sic bestiae, sic /aves, sic capiuntur et pisces. Modica in hamo ${ }^{17} \mathrm{esca}$ ponitur, ut matronarum in eo ${ }^{18}$ sacculi protrahantur.

Cave ne hominum ${ }^{19}$ rumusculos ${ }^{20}$ aucuperis, ne in ${ }^{21}$ offensum Dei populorum laudem commutes. Si adhuc, inquit Apostolus, homi-

1 lepores =facetiousness.

fession. 4 formidem, I 56 .
3 propositum = pro. 5 rabulam $=a$ bawler.

indoctorum hominum est, $27 . \quad \cdot 7$ vilem plebiculam = the low common people. $\quad{ }^{8}$ concionem =audzence. $\quad{ }^{9}$ pullas $=$ dark. $\quad{ }^{10}$ sordes=untidiness. $\quad{ }^{11}$ gloriam =ostentation. $\quad 12$ absque = sine, 207.

14 orarium = handkerchief. $\quad{ }^{16}$ gloriari = to boast.

17 esca $=a$ bait.

18 sacculi = money-bags.

20 aucuperis $=$ fish for.

21 offensum Dei. Objective Gen., 24. 
nibus placerem, Christi servus non essem. Per bonam famam et malam, a dextris et a sinistris, Christi miles graditur, nec laude extollitur, nec vituperatione frangitur: non divitiis tumet, non ${ }^{1}$ contrahitur paupertate, et ${ }^{2}$ laeta contemnit et ${ }^{2}$ tristia: per diem sol non urit eum, neque luna per noctem.

* * * * * * *

Cave quoque, ne aut linguam, aut aures habeas ${ }^{3}$ prurientes: id est, ne aut ipse aliis ${ }^{4}$ detrahas, aut alios audias detrahentes. Parce a detractione linguae: custodi sermones tuos: et scito, quia per cuncta, quae de aliis loqueris, tuā sententiā judicaris, et in his ipse ${ }^{5}$ deprehenderis, quae in aliis ${ }^{6}$ arguebas. Neque vero illa justa est excusatio: 'Referentibus aliis injuriam facere non possum. Nemo invito auditori libenter refert. Sagitta in lapidem nunquam fingitur, interdum resiliens percutit dirigentem. Discat detractor, dum te videt non libenter audire, non facile detrahere. Cum detractoribus, ait Solomon, ne miscearis: quoniam repente veniet perditio eorum, et ruinam utriusque quis novit? tam videlicet ejus qui detrahit, quam illius qui accommodat aurem detrahenti.

Officii tui est visitare ${ }^{8}$ languentes, nosse domos matronarum et liberos earum, et nobilium virorım custodire secreta. Officii tui sit, non solum oculos castos servare, sed et linguam. Nunquam de formis mulierum disputes, nec quid agatur in aliā, domu alia per te noverit. Hippocrates adjurat discipulos suos antequam ${ }^{9}$ doceat, et in verba sua jurare compellit, ${ }^{10}$ extorquet sacramento silentium, sermonem, incessum, habitum moresque praescribit. Quanto magis nos, quibus animarum medicina commissa est, omnium Christianorum domos debemus amare, quasi proprias? Consolatores potius nos in maeroribus suis, quam convivas in prosperis noverint. Facile contemnitur clericus, qui saepe vocatus ad prandium, ire non recusat.

Nunquam petentes, raro accipiamus rogati. Beatius enim est magis dare quam accipere. Nescio quo enin modo etiam ipse, qui deprecatur ut tribuat, cum acceperis, viliorem te judicat: et mirum in modum, si eum rogantem contempseris, plus te posterius veneratur.

Extracts from Ep. ad Nepontianum.

1 contrahitur = abased.

2 Jeta, tristia, 200 .

${ }^{3}$ prurientes $=$ itching, II Tin. iv, 3. $\quad$ detrahere=slander. $\quad{ }^{5}$ deprehenderis =you are caught. ${ }^{6}$ arguebas =you were reproving. ${ }^{7}$ Referentibus aliis = when others tell stories.

8 languentes $=$ the sick.

9 doceat, I 53.

10 extorquet $=$ exacts. 
Augustine (died 430), Bishop of Hippo, the most famous of the Latin Fathers, was born in Tagaste in Numidia. His father Patricius was a man of humble origin and indifferent character, his mother Monnica was a devout Christian woman who has been immortalised by her son in his Confessions. According to his own account he was not a diligent scholar, although his parents tried to give him the best education that was possible at the time. He never mastered Greek, much to his own disadvantage. After a dissolute youth he joined the sect of the Manichaeans, and, finally, after a long period of spiritual struggle, he was converted to Catholic Christianity by the influence of his mother and the teaching of Ambrose, Bishop of Milan. He was baptized in 387 in the 33 rd year of his age, and gave up his profession as a teacher of rhetoric in order that he might retire from the world into a religious community. Shortly after this his mother died at Ostia and he returned to Africa where he was consecrated Bishop of Hippo in 395. His influence extended far beyond his unimportant see.

By his letters and his treatises he influenced the whole Cliristian world, and has influenced it ever since. Probably no Christian teacher after the time of the Apostles ever had such influence both for good and evil. Both the supporters of the ecclesiastical system of the middle ages and the German and French reformers claimed to found their teaching on the writings of Augustine.

Augustine's style is difficult and strikingly original. Only two passages from his voluminous writings are included here: both from the Confessions.

Of the two passages from the Confessions the first gives his account of his education, and is interesting because of his curiously modern views with regard to the "direct method" in language teaching, and for the preference which he shows for the Gradgrind type of education in "facts" in comparison with the training of the higher faculties of imagination and susceptibility through literature and humanism.

The general sentiment of the Church did not follow him in this: the common-sense of the Italian temperament prevailed over the rigor of the fiery African.

It would have been well for himself as well as for the Church at large if Augustine had not counted such natural feelings to be a sin, but had imbibed a little more of the humanity of Vergil,

majestic in his sadness

At the doubtful doom of human kind,

and of the spirit of the famous line

Sunt lacrymae rerum, et mentem mortalia tangunt.

In the second extract we see Augustine at his best, not as the pitiless logician, or as the victorious controversialist, but as a ma11. 
Augustine's works are accessible as a whole in Migne, Patrologia Latina, and portions of them are published in SS. Patrum Opuscula, by the Oxford and Cambridge Presses, and in the Loeb Library. An excellent translation of the Confessions by Dr Bigg is published by Methuen.

\section{De miseris Augustini in pueritia.}

Deus, Deus meus, quas ibi miserias expertus sum et ${ }^{\mathbf{1}}$ ludificationes: ${ }^{2}$ quandoquidem recte mihi vivere puero id proponebatur, ${ }^{3}$ obtemperare monentibus, ut in hoc saeculo florerem, et excellerem ${ }^{4}$ lignosis artibus, ad honorem hominum et falsas divitias ${ }^{5}$ famulantibus. Inde in scholam datus sum ut discerem litteras, in quibus quid utilitatis esset ignorabam miser, et tamen si segnis in discendo ${ }^{6}$ essem, ${ }^{7}$ vapulabam. Laudabatur enim hoc a majoribus; et multi ante nos vitam istam agentes, praestruxerant ${ }^{8}$ aerumnas vias, per quas transire cogebamur, multiplicato labore et dolore filiis Adam.

${ }^{9}$ Invenimus autem, Domine, homines rogantes te, et didicimus $\mathrm{ab}$ eis, sentientes te, ut poteramus, esse magnum aliquem, qui posses, etiam non apparens sensibus nostris, exaudire nos, et subvenire nobis. Nam puer coepi rogare te, auxilium et refugium meum, et in ${ }^{10}$ tuam invocationem rumpebam nodos linguae meae, et rogabam te parvus, non parvo affectu, ne in scholà vapularem. Et cum me non exaudiebas, ${ }^{11}$ quod non erat ad insipientiam mihi, ridebantur a majoribus hominibus, usque ab ipsis parentibus, qui mihi accidere mali nihil volebant, ${ }^{12}$ plagae meae, magnum tunc et grave malum meum.

* $\quad * \quad * \quad * \quad * \quad * \quad * \quad *$

Quid autem ${ }^{13}$ erat causae cur Graecas ${ }^{14}$ litteras oderam, quibus puerulus jmbuebar, ne nunc quidem mihi satis exploratum est.

1 ludificationes = delusions. fore the as the right way for a boy to live. 'id,' I 45. with artibus $=$ enslaved $t o$.

8 aerumnas, here used as an adjective = gricvous.
2 quandoquidem... = since this was set be3 obtemperare monentibus explains we learnt from them, perceiving, found men, $O$ Lord, who prayed to Thee, and we learnt from them, perceiving, as far as we were able, that Thou wert some great Being who couldst hear us. 10 tuam invocationem. Possessive pronoun in sense of obj. gen., 25. ${ }^{11}$ quod non erat ad insipientiam mihi. Cf. Ps. xxi, 3 Deus meus, clamabo per diem et non exaudies me: et nocte et non ad insipientiam mihi. Translate: which Thou didst not reckon as folly to me. ${ }^{12}$ plagae meae. Subject of ridebantur. 13 erat. For the Ind. in indirect questions, see I43, I44.

16 litteras, trans. studies. 


\section{Augustine}

${ }^{1}$ Adamaveram enim Latinas, non quas primi magistri, sed quas docent qui ${ }^{2}$ grammatici vocantur. Nam ${ }^{3}$ illas primas ubi legere et scribere et numerare discitur, non minus onerosas poenalesque habebam, quam omnes Graecas. Unde tamen et hoc nisi de peccato et vanitate vitae, qua caro eram et spiritus ambulans et non revertens? Nam utique meliores, quia certiores erant primae illae litterae, quibus fiebat in me, et factum est, ${ }^{4}$ et habeo illud ut et legam si quid scriptum invenio, et scribam ipse si quid volo, quam illae quibus ${ }^{5}$ tenere cogebar ${ }^{6}$ Aeneae nescio cujus errores, oblitus errorum meorum, et plorare Didonem mortuam, quia se occidit ob amorem, cum interea meipsum in his a te morientem, Deus vita mea, siccis oculis ferrem miserrimus.

At enim ${ }^{7}$ vela pendent liminibus grammaticarum scholartum: sed non illa magis honorem secreti, quan tegumentum erroris significant. Non clament adversum me venditores grammaticae vel emptores; quia, si proponam eis, interrogans utrum sit verum quod ${ }^{8}$ Aeneam aliquando Carthaginem venisse poeta dicit; indoctiores se nescire respondebunt, doctiores autem etiam negabunt verum esse.

At si quaeram quibus litteris scribitur Aeneae nomen, omnes mihi, qui haec didicerunt, verum respondebunt, secundum id pactum et placitum, quo inter se homines ista signa ${ }^{9}$ firmarunt.

${ }^{10}$ Item, si quaeram quid horum majore hujus vitae incommodo quisque obliviscatur, legere et scribere, an poetica illa figmenta, quis non videat quid responsurus sit, qui non est penitus oblitus sui? Peccabam ergo puer cum illa inania istis utilioribus amore praeponebam, vel potius ista oderam, illa amabam.

Jamvero unum et unum duo, duo et duo quatuor, odiosa cantio mihi erat, et dulcissimum spectaculum vanitatis equus ligneus plenus armatis et Trojae incendium, atque ipsius umbra Creusae.

Cur ergo Graecam etiam grammaticam oderam talia cantantem?

1 Adamaveram $=I$ loved greatly.

3 illas primas, understand litteras.
2 grammatici $=$ teachers of literature.

4 et habeo illud ut et legam, etc., I45.

5 tenere $=$ to remember. $\quad$ 'Aeneae nescio cujus $=$ of one Aeneas. 7 vela $=$ curtains. 8 Aeneam aliquando venisse, in apposition with 'quod.' 9 firmarunt $=$ have established. 10 I tem, si quaeram, etc. $=A$ nd if $I$ ask which of these things, namely to read and to write, or these poetic fablcs, would cause the greatest inconvenience in this life to any one who should forget them. 
Nam et Homerus peritus texere tales fabulas, et dulcissime vanus est, et mihi tamen amarus erat puero.

${ }^{1}$ Credo etiam Graecis pueris Virgilius ita sit, cum eum sic discere coguntur, ut ego illum. Videlicet difficultas, difficultas omnino ediscendae peregrinae linguae, quasi ${ }^{2}$ felle aspergebat omnes suavitates Graecas fabulosarum narrationum. Nulla enim verba illa noveram, et saevis terroribus ac poenis ut nossem ${ }^{3}$ instabatur mihi vehementer. Nam et Latina aliquando infans nulla noveram; et tamen ${ }^{4}$ advertendo didici sine ullo metu et cruciatu, inter etiam blandimenta nutricum et joca arridentium et laetitias alludentium.

Didici vero illa sine poenali onere urgentium cum me urgeret cor meum ad parienda concepta sua, quae non possem, nisi aliqua verba didicissem, non a docentibus sed a loquentibus, ${ }^{5}$ in quorum et ego auribus parturiebam quidquid sentiebam. Hinc satis elucet majorem habere vim ad discenda ista liberam curiositatem, quam ${ }^{6}$ meticulosam necessitatem.

Confessions i, I 4, 20, 22, 23 (selections).

\section{Augustini oratio pro Monnica matre sua.}

Ego autem, jam sanato corde ab illo 'vulnere in quo poterat ${ }^{8}$ redargui carnalis affectus, fundo tibi, Dens noster, pro illā famulā tuā longe aliud lacrymarum genıs, quod manat de concusso spiritu ${ }^{9}$ consideratione periculorum omnis animae quae in Adam moritur. Quamquam illa in Christo vivificata, etiam nondum a carne resoluta, sic vixerit ut laudetur nomen tuum in fide moribusque ejus; non tamen audeo dicere, ex quo eam per Baptismum regenerasti, nullum verbum exisse ex ore ejus contra praeceptum tuum. Et dictum est a Veritate Filio tuo: Si quis dixerit fratri suo, Fatue, reus erit gehennae ignis.

Et vae etiam laudabili vitae hominum, ${ }^{10} \mathrm{si}$, remotā misericordiã, discutias eam. Quia vero non exquiris delicta vehementer, ${ }^{11}$ fiducialiter speramus aliquem apud te locum. Quisquis autem tibi

${ }^{1}$ Credo Graecis pueris... =I believe that Vergil is as hateful to Greek boys when they are compelled to learn him in the same way, as I was compelled to learn Homer. ${ }_{2}^{2}$ felle= with gall. $\quad{ }^{3}$ instabatur=pressure was brought to bear on me. ${ }^{4}$ advertendo $=b y$ paying attention. $\quad{ }^{5}$ in quorum auribus, etc. $=$ in whose cars I was travailing to express my thoughts. ${ }^{6}$ meticulosam necessitatem = pedantic compulsion. $\quad 7$ vulnere, i.e. the grief that he felt at the death of his mother. $\quad{ }_{8}^{8}$ redargui $=$ be blamed. $\quad{ }^{9}$ consideratione $=$ at the thought of. ${ }^{10}$ si, remotã misericordiā, discutias=if thou shouldst sift it without pity. 11 fiducialiter $=$ confidently. 


\section{Augustine}

enumerat vera merita sua, quid tibi enumerat nisi munera tua? ${ }^{1} \mathrm{O}$ si cognoscant se lomines homines; et qui gloriatur, in Domino glorietur.

Ego itaque, laus mea et vita mea, Deus cordis mei, sepositis paulisper bonis ejus actibus, pro quibus tibi gaudens gratias ago, nunc pro peccatis matris meae deprecor te: exaudi me per Medicinam vulnerum nostrorum, quae pependit in ligno, et sedens ad dexteram tuam interpellat te pro nobis. Scio misericorditer operatam, et ex corde dimisisse debita debitoribus suis: dimitte illi ct tu debita sua, si quā etiam contraxit per tot annos post aquanı salutis. Dimitte, Domine, dimitte obsecro, ne intres cum ea in judicium.

${ }^{2}$ Superexaltet misericordia judicio, quoniam ${ }^{3}$ eloquia tua vera. sunt, et promisisti misericordiam misericordibus: quod ut essent, tu dedisti eis, qui misereberis cui misertus eris, et misericordiam praestabis cui misericors fueris.

Et credo ${ }^{4}$ quod jam feccris quod te rogo, sed ${ }^{5}$ voluntaria oris mei approba, Domine. Namque illā imminente die resohtionis suae non cogitavit suum corpus sumptuose contegi, aut condiri aromatibus, aut monumentum electum concupivit, aut curavit sepulcrum patrium; non ista mandavit nobis; sed tantummodo ${ }^{6}$ memoriam sui ad altare tuum fieri desideravit, cui nullius diei praetermissione servierat, unde sciret dispensari victimam sanctam, quā deletum est ${ }^{7}$ chirographum, quod erat contrarium nobis, quā triumphatus est hostis computans delicta nostra, et quaerens quid objiciat, et nihil inveniens in illo, in quo vincimus. Quis ei refundet innocentem sanguinem? Quis ei restituet pretium, quo nos emit, ut nos auferat ${ }^{8}$ ei? Ad cujus pretii nostri sacramentum ligavit ancilla tua aninam suam vinculo fidei. Nemo a protectione tuá disrumpat eam. Non se interponat nec vi nec insidiis leo et draco; neque enim respondebit illa nihil se debere, ne convincatur et obtineatur ab accusatore callido; sed respondebit dimissa lebita sua ab eo, cui nemo reddet quod pro nobis, non debens, reddidit.

Sit ergo in pace cum viro, ante quem nulli, et post quem nulli, nupta est; cui servivit ${ }^{9}$ fructum tibi afferens cum toierantiā, ut eum quoque ${ }^{10}$ lucraretur tibi.

1 O si cognoscant, etc. $=O$ that men may know themselves to be but men. 2 Superexaltet misericordia judicio, Jas. ii, $\mathrm{I}_{3} .{ }^{3}$ eloquia $=$ words. ${ }^{4}$ quod jam feceris, II2-1 I5, I35. 5 voluntaria=the frec-will offerings of my mouth. ${ }_{6}$ memoriam sui, objective gen., 24 . Col. ii, I4. ${ }^{8}$ ei: that is, from the devil. ${ }^{10}$ lucraretur = that she might gain.

${ }^{7}$ chirographum = the handwriting,

9 fructum, i.e. A ugustine her son. 
Et inspira, Domine Deus meus, inspira servis tuis fratribus meis, filiis tuis, dominis meis, quibus et corde et voce et litteris servio, ut ${ }^{1}$ quotquot haec legerint, meminerint ad altare tuum Monnicae famulae tuae, cum Patricio quondam ejus conjuge, per quorum carnem induxisti me in hanc vitam, quemadmodum nescio.

Meminerint cum affectu pio parentum meorum in hāc luce transitoriā, et ${ }^{2}$ fratrum meorum sub te Patre in matre Catholicā, et civium meorum in aeternā Jerusalem, cui suspirat ${ }^{3}$ peregrinatio populi tui ab exitu usque ad reditum; ut, quod a me illa poposcit extremum, ${ }^{4}$ uberius ei praestetur in multorum orationibus, per confessiones, quam per orationes meas.

Confessions ix, 34 .

Bede (died 735), a monk of Jarrow, was among the greatest scholars of the early middle ages. He was acquainted with all the knowledge of his day although he never travelled out of England. He had read the Latin Classics as well as the Latin Fathers and had some knowledge of Greek and Hebrew. His most famous work is the History of the Saxon Church from which some extracts are here given.

His style shows considerable departure even from the Latin of the early Fathers, but this is only to be expected considering the barbarous times in which he lived and the distance that separated Jarrow from Italy. When he makes use of Classical expressions his correctness is rather that of a scholar who has learnt his style from books, than that of an original writer who is taking his part in the development of a language. The study of his works makes us marvel at the vigour of the Latin language which could extend its influence so far. The learning of Bede, handed on by Alcuin to the schools of Charlemagne, did much to help the first revival of letters in Europe.

\section{De vita Beati Papae Gregorit.}

Beatus papa Gregorius natione erat Romanus, a patre Gordiano, genus a ${ }^{5}$ proavis non solum nobile sed ${ }^{6}$ religiosum ducens. Felix denique ejusdem apostolicae sedis quondam episcopus, vir magnae gloriae in Christo et ecclesiā, ejus fuit ' atavus. Nobilitatem vero

1 quotquot=as many as.

2 fratrum. Augustine calls his parents his hrethren 1 ecause they had one Father in God and one Mother in the Church. ${ }^{3}$ peregrinatio $=$ pilgrimage. $\quad{ }^{4}$ uberius = more abundantly. ancestors. ${ }^{-}$religiosum = attached to the observances of religion. 5 proavis $=$ father (1) his grcat grandfather.

7 atavus $=$ the 
illam quam ad ${ }^{1}$ saeculum videbatur habere, totam ${ }^{2}$ ad nanciscendam supernae gloriam dignitatis divinā gratia ${ }^{3}$ largiente convertit. Nam mutato repente habitu ${ }^{4}$ saeculari, monasterium petiit, in quo tantā perfectionis gratiā coepit ${ }^{5}$ conversari, ut, sicut ipse postea ${ }^{6}$ flendo solebat adtestari, nulla nisi caelestia cogitare ${ }^{7}$ soleret, ut etiam retentus corpore, ipsa jam carnis ${ }^{8}$ claustra contemplatione transiret, ut mortem quoque, quae paene cunctis poena est, ut ingressum vitae, et laboris sui praemium amaret. Hoc antem ipse de se, non profecto ${ }^{9}$ jactando virtutem, sed deflendo potius defectum, quen sibi per curam pastoralem incucurrisse videbatur, referre consueverat. Mox ${ }^{10}$ pontificali functus officio domum suam monasterium facere curavit. Quin etiam dum alii pontifices construendis ornandisque ecclesiis auro vel argento operam dabant, hic autem quidquid pecuniae habuerat sedulus hoc dare pauperibus curabat, ut justitia ejus maneret ${ }^{11}$ in saeculum saeculi, et cornu ejus exaltaretur in gloriā.

Ad cujus pietatis et justitiae opus pertinet etiam hoc, ${ }^{12}$ quod nostram gentem per praedicatores quos huc direxit de dentibus antiqui hostis eripiens, aeternae libertatis fecit participem. Nec silentio praetereunda ${ }^{13}$ opinio quae de beato Gregorio traditione majorum ad nos usque perlata est: quā videlicet ex causā admonitus, tam sedụlam erga salutem nostrae gentis curan gesserit. ${ }^{14}$ Dicunt quia die quādam cum, advenientibus nuper mercatoribus, multa ${ }^{15}$ venalia in forum fuissent conlata, multique ad emendum confluxissent, et ipsum Gregorium inter alios advenisse, ac vidisse inter alia pueros venales positos, ${ }^{16}$ candidi corporis et venusti

1 saeculum =an age, hence this life. $\quad 2$ ad nanciscendam supernae gloriam dignitatis = to obtaining the glory of the heavenly crown, rgo. ${ }^{3}$ largiente $=$ granting. $\quad{ }^{4}$ saecularis $=$ worldly. Compare the use of the expression secular clergy in opposition to regular clergy. $\quad{ }^{5}$ conversari = to live, to behave one's self. Compare the use of the word conversation in A.V. of Gal. i, I3, Jas. iii, I3. ${ }^{6}$ flendo=weeping, I88. "soleret, transiret, amaret, consecutive, 163 . 8 claustra =bonds. 9 jactando $=b y$ way of boasting, I9I. ${ }^{10}$ pon + ificali, i.e. he was made Pope. The Bishops of Rome took over this title from the ancient Romans. For the case see 57. 11 in saeculum saeculi $=$ for cyer $^{2}$ and ever. ${ }_{12}$ quod =namely that. It is easy to see from an example like this how clauses introduced by 'quod' came to be used as noun clauses. See III-II5. ${ }^{13}$ opinio $=$ story. $\quad{ }^{14}$ dicunt quia. Two const. are confused in this sentence. Bede began by writing a subordinate clause introduced by 'quia' after the verb 'dicunt' which should have contained verbs in the indicative or subj. mood: he however turned off into the ordinary Classical const. of the Acc. and Inf. and wrote the verbs in the Inf., leaving 'quia' in the air. See II2-II5 and I3O, I32. 15 venalia $=$ objects for sale.

16 candidi corporis, 26. 
vultūs, capillorum quoque ${ }^{1}$ formā egregiā. Quos cum aspiceret, interrogavit, ut aiunt, de quā regione vel terrā ${ }^{2}$ essent adlati. Dictumque est quod de Britanniā insulā, cujus incolae talis essent aspectūs. Rursus interrogavit utrum iidem insulani Christiani an paganis adhuc erroribus ${ }^{2}$ essent implicati. Dictumque est quod essent pagani. At ille intimo ex corde longa trahens suspiria "Heu," inquit, "quod tam lucidi vultūs homines tenebrarum auctor possidet." Rursus ergo interrogavit, " quod esset vocabulum illius gentis. Responsum est quod Angli vocarentur. At ille "Bene," inquit, "nam et angelicam habent faciem, et tales angelorum in caelis decet esse coheredes. Quod habet nomen ipsa provincia de quā isti sunt adlati?" Responsum est quod Deiri vocarentur iidem provinciales. At ille: "Bene," inquit, "Deiri, de irā eruti, et ad misericordiam Christi vocati. Rex provinciae illius quomodo appellatur?" Responsum est quod Aella diceretur. At ille adludens ad nomen ait: "Alleluia: laudem Dei creatoris illis in partibus oportet cantari."

Accedensque ad pontificem Romanae et apostolicae. sedis, nondum erat enim ipse pontifex factus, rogavit ut ${ }^{3}$ genti Anglorum in Britanniam aliquos verbi ministros, per quos ad Christum converteretur, mitteret. Mox ipse, pontificatūs officio functus, perfecit opus diu desideratum, praedicatores ad Britanniam mittens, et ipse praedicationem, ut fructificaret, suis exhortationibus ac precibus adjuvans.

Rexit ecclesiam temporibus imperatorum Mauricii et Focatis. Secundo autem ejusdem Focatis anno transiens ex hāc vitā migravit ad veram quae in caelis est vitam. Sepultus vero est corpore in ecclesiā beati Petri apostoli; scriptum est in tumbā epitaphium hujusmodi :

Suscipe, terra, tuo corpus de corpore sumptum,

Reddere quod ${ }^{4}$ valeas, vivificante Deo.

Spiritus astra petit, leti nil jura nocebunt

Cui vitae alterius mors magis ipsa via est.

Pontificis summi hoc clauduntur membra sepulcro,

Qui innumeris semper vivit ubique bonis.

${ }^{5}$ Esuriem ${ }^{6}$ dapibus superavit, frigora veste,

1 formà egregiā, 56.

lum, I 43.

${ }^{3}$ genti, 39 .

2 essent adlati, essent implicati, quod esset 1 ocabu4 valeas... = which thou mayest have power to give back whcn God quickeneth it, I 50 (2). fcasts. 


\section{Bede}

Atque animas monitis texit ab hoste sacris.

Implebat actu quidquid sermone docebat,

Esset ut exemplum, mystica verba loquens.

Ad Clıristum Anglos convertit pietate magistrā,

Adquirens fidei agmina gente novā.

Hic labor, hoc studium, haec tibi cura, hoc ${ }^{1}$ pastor agebas,

Ut Domino offerres plurima lucra gregis.

Hisque, Dei consul, factus laetare triumphis:

Nam mercedem operum jam sine fine tenes.

Hist. Ecc., Book 2 (adapted).

De adventu Augustini ad praedicandum genti Anglorum.

Anno ab incarnatione Domini quingentesimo octogesimo secundo, regnante imperatore Mauricio, Gregorius, vir doctrinā et actione praecipuus, pontificatum Romanum et apostolicae sedis ${ }^{2}$ sortitus, misit servum Dei Augustinum et alios plures cum eo monachos timentes Dominum ${ }^{3}$ praedicare verbum Dei genti Anglorum.

${ }^{4}$ Qui cum jussis pontificalibus obtemperantes hoc opus adgredi coepissent, perculsi timore, redire domum potius, quanı barbaram, feram, incredulamque gentem, cujus ne linguam quidenı ${ }^{5}$ nossent, adire cogitabant et hoc esse tutius communi consilio decernebant.

Nec mora, Augustinum, quem eis ${ }^{6}$ episcopum ordinandum si ab Anglis susciperentur disposuerat, domum remittunt, qui a beato Gregorio humili supplicatu ${ }^{7}$ obtineret ne tam periculosam, tam laboriosam, tam incertam peregrinationem adire deberent. ${ }^{4}$ Quibus ille exhortatorias mittens litteras, in opus ${ }^{8}$ eos verbi, divino confisos auxilio, proficisci suadet. Quarum videlicet litterarum ista est forma:

"Gregorius servus servorum Dei, servis Domini nostri. Quia melius fuerat bona non incipere, quam ab his quae coepta sunt, cogitatione retrorsum redire, summo studio, dilectissimi filii, oportet ut opus bonum, quod auxiliante Deo coepistis, impleatis.

1 pastor = as shepherd. $\quad 2$ sortitus =having been allotted. ${ }^{3}$ praedicare, 157a, $162 . \quad 4 \mathrm{Qui}=b$ ut they, 66. ${ }^{5}$ nossent, the subj. is used because the words state their thought indirectly. Their actual thought was "Ne linguam quidem novimus." "episcopum ordinandum = to be ordained bishop, I 88 . ${ }^{7}$ qui obtineret $=$ to obtain, I50 (2).

have been used in $\mathrm{Cl}$. L., 37 . 
Nec labor ergo vos itineris, nec ${ }^{1}$ maledicorum hominum linguae deterreant: sed omni instantiā, omnique fervore, quae inchoastis, Deo auctore, peragite: ${ }^{2}$ scientes quod laborem magnum major aeternae retributionis gloria sequitur. ${ }^{3}$ Remeanti autem Augustino, praeposito vestro, quem et abbatem vobis constituimus, in omnibus humiliter obedite. Omnipotens Deus suā vos gratiā ${ }^{4}$ protegat, et vestri laboris fructum in aeternā me patriā videre concedat; quatenus etsi vobiscum laborare nequeo, simul in gaudio retributionis inveniar, quia laborare scilicet volo. Deus vos incolumes custodiat, dilectissimi filii.'

Roboratus ergo confirmatione patris Gregorii, Augustinus cum famulis Christi, qui erant cum eo, rediit in opus verbi, pervenitque Britanniam. Erat eo tempore rex Aedilberctus in Cantiā potentissimus. Est autem ad orientalem Cantiae plagam Tanatos insula non modica. In hāc ergo ${ }^{5}$ adplicuit Augustinus et socii ejus.

Acceperunt autem de gente Francorum interpretes, et mittens ad Aedilberctum, ${ }^{6}$ mandavit se venisse ${ }^{7}$ de Romā, ac nuntium ferre optimum, qui ${ }^{8}$ sibi obtemperantibus aeterna in caelis gaudia, et regnum sine fine cum Deo vivo et vero futurum sine ullā dubietate ${ }^{9}$ promitteret. ${ }^{10}$ Qui haec audiens, manere illos in eā, quam aderant insulā, et eis necessaria ministrari, donec videret quid eis faceret jussit. Nam et antea fama ad eum Christianae religionis pervenerat, utpote qui uxorem habebat Christianam de gente Francorum regiā, ${ }^{11}$ vocabulō Bercta; quam eà conditione a parentibus acceperat, ut ritum fidei ac religionis suae cum episcopo quem ei adjutorem fidei dederant, nomine Liudhardo, inviolatum servare licentiam haberet. Post dies ergo venit ad insulam rex, et residens ${ }^{12}$ sub divo, jussit Augustinum cum sociis ${ }^{13}$ ad suum ibidem advenire colloquium. Caverat enim ne in aliquam domum ad se introirent, vetere usus augurio, ne ${ }^{14}$ superventu suo, si quid malificae artis habuissent, eum superando deciperent. At illi non daemonicā sed divinā virtute praediti veniebant, crucem pro

1 maledicorum =men of strange speech. $\quad{ }^{2}$ scientes =because you know, 183 . 3 Remeanti. For the use of the present participle to denote action previous to the main verb see $\mathrm{r} 77, \mathrm{I} 78$. Trans. When A ugustine returns. 1 protegat, ror. ${ }^{5}$ adplicuit =landed. ${ }^{6}$ mandavit=he stated. ${ }^{7}$ de Roma, 45, 2 I I. ${ }^{8} \mathrm{sibi}=$ to those that obeyed it. This is rather a loose use of 'sibi,' 61. mitteret, I50 (I). ${ }^{10}$ See p. I 39, n. +. $\quad{ }^{11}$ vocabulō Bercta =Bertha by name. 12 sub divo $=$ in the open air. Cf. Vitamque sub divo et trepidis agat in rebus, Hor. 3. 2, 5. ${ }^{13}$ ad suum colloquium =to speak with him, 25. ${ }^{14}$ superventu suo $=$ by their craft. 
${ }^{1}$ vexillo ferentes argenteam, et imaginem Domini Salvatoris in tabulā depictam, 2 litaniasque canentes, pro suā simul et eorum ad quos venerant salute aeternā Domino supplicabant. Cumque ad jussionem regis residentes, verbum ei vitae praedicarent, respondet ille dicens: "Pulcra sunt quidem verba et promissa quae adfertis; sed quia nova sunt, et incerta, non his possum adsensum tribuere, relictis eis quae ${ }^{3}$ tanto tempore cum omni Anglorum gente servavi. Verum quia de longe huc peregrini venistis, et ut ego mihi videor perspexisse, ea quae vos vera et optima credebatis, nobis quoque communicare desiderastis, nolumus molesti esse vobis: quin potius benigno vos hospitio recipere, et quae victui sunt vestro necessaria, ministrare curamus; nec prohibemus quin omnes quos potestis fidei vestrae religionis praedicando societis."

Dedit ergo eis mansionem in civitate Doruvernensi, quae imperii sui totius erat metropolis, eisque, ut promiserat, cum administratione victūs temporalis, licentiam quoque praedicandi non abstulit. Fertur autem quia adpropinquantes civitati, more suo cum crucesanctā, et imagine magni regis Domini nostri Jesu Christi, hanc litaniam consonā voce modularentur: "Deprecamur te, Domine, in omni misericordiā tuā, ut auferatur furor tuus et ira a civitate istā, et de domo sanctā tuã, quoniam peccavimus. Alleluia."

At ubi datam sibi mansionem intraverant, coeperunt apostolicam primitivae ecclesiae vitam imitari; orationibus videlicet assiduis, vigiliis, et jejuniis ${ }^{4}$ serviendo, verbum vitae quibus poterant praedicando, cuncta hujus mundi velut aliena spernendo, ea tantum quae victui necessaria videbantur, ab eis quos docebant, accipiendo, secundum ea quae docebant ipsi per omnia vivendo.

${ }^{5}$ Quid mora? Crediderunt nonnulli et baptizabantur, mirantes simplicitatem innocentis vitae, ac dulcedinem doctrinae eorum caelestis. Erat autem prope ipsam civitatem ad orientem ecclesia in honorem Sancti Martini ${ }^{6}$ antiquitus facta dum adhuc Romani Britanniam incolerent, in quā regina, quam Christianam fuisse praediximus, orare consueverat. In hāc ergo et ipsi primo convenire, psallere, orare, missas facere, praedicare et baptizare coeperunt; donec, rege ad fidem converso, majorem praedicandi per omnia, et ecclesias fabricandi vel restaurandi licentiam acciperent.

1 vexillum =a banner.

2 litaneas $=$ litanies.

3 tanto tempore, 55 . ${ }^{4}$ serviendo, praedicando, spernendo, accipiendo, vivendo. For the use of the ablative of the Gerund in the sense of a present participle see I88. 'B Quid mora $=$ why say more?

${ }^{6}$ antiquitus, an adverb $=$ in ancient times. 
At ubi ipse etiam inter alios delectatus vitā mundissimā sanctorum, et promissis eorum suavissimis, quae vera esse miraculorum quoque multorum ostensione firmaverant, credens baptizatus est, coeperunt ad audiendum verbum confluere, ac, relicto gentilitatis ritu, unitati se sanctae Christi ecclesiae ${ }^{1}$ credendo sociare.

Hist. Ecc. (adapted).

\section{De colloguio Augustini cum Episcopis Brittonum.}

Interea Augustinus ${ }^{2}$ adjutorio usus Aedilbercti, convocavit ${ }^{3} \mathrm{ad}$ suum colloquium episcopos proximae Brittonum provinciae, coepitque eis fraternā admonitione suadere, ut pace catholicā secum habitā, communem evangelizandi gentibus pro Domino laborem susciperent. Non enim ${ }^{4}$ Paschae Dominicum diem suo tempore, sed a quartā decimā usque ad vicesimam lunam observabant, et alia plurima unitati ecclesiasticae contraria faciebant. Qui cum longā disputatione habitā neque precibus, neque hortamentis, neque increpationibus Augustini ac sociorum ejus assensum praebere voluissent, sed suas potius traditiones universis, quae per orbem sibi in Christo concordant, ecclesiis praeferrent, sanctus pater Augustinus hunc laboriosi atque longi certaminis finem fecit ${ }^{5}$ ut diceret: "Obsecremus Deum, qui habitare facit unanimes in domo Patris sui, ut nobis ${ }^{6}$ insinuare caelestibus signis dignetur, quae sequenda traditio, quibus sit viis ad ingressum regni illius properandum. Adducatur aliquis aeger, et per cujus preces fuerit ${ }^{7}$ curatus, hujus fides et ${ }^{8}$ operatio Deo ${ }^{9}$ devota atque omnibus sequenda credatur." Quod cum adversarii inviti licet concederent, allatus est quidam de genere Anglorum oculorum ${ }^{10}$ luce privatus: qui cum oblatus Brittonum sacerdotibus, nil ${ }^{\mathbf{1 1}}$ curationis vel sanationis horum ministerio perciperet; tandem Augustinus justā necessitate compulsus, flectit genua sua ad Patrem Domini nostri Jesu Christi, deprecans ut visum caeco quem amiserat, restitueret, et per illuminationem unius hominis corporalem, in plurimorum corde fidelium spiritalis gratiam lucis accenderet. Nec mora, illuminatur caecus, ac verus summae lucis ${ }^{12}$ praeco ab omnibus praedicatur Augustinus. Tum Brittones confitentur quidem in-

1 See p. I 4 I, n. 4 . converse with him, 25. 5 ut diceret $=$ by saying; consecutive subj. xvii, $3 \mathrm{Vg}$. secraled.
2 adjutorio $=$ help.

4 Paschae Dominicum diem = the feast of Easter.

3 ad sum colloquium $=$ to
diem $=$ the feast of Easter. 6 insinuare $=$ to explain; Acts

8 operatio $=$ practice.

11 curatio $=$ cure. devota $=$ con12 praeco $=$ herald. 
tellexisse se veram esse viam justitiae, quam ${ }^{1}$ praedicaret Augustinus: sed non se posse ${ }^{2}$ absque suorum consensu ac licentiā priscis abdicare moribus. Unde postulabant ut secundus synodus pluribus advenientibus foret. Quod cum esset statutum, venerunt, ut perhibent, septem Brittonum episcopi et plures viri doctissimi, qui ad prefatum ${ }^{3}$ ituri concilium, venerunt primo ad virum quendam sanctum et prudentem consulentes an ad praedicationem Augustini suas deserere traditiones deberent. Qui respondebat: "Si homo Dei est sequimini illum." Dixerunt: "Et unde hoc possumus probare?" At ille: "Dominus," inquit, "ait: "Tollite jugum meum super vos, et discite a me quia mitis sum et humilis corde.' Si ergo Augustinus ille mitis est et humilis corde, credibile est ${ }^{\mathbf{4}}$ quia jugum Christi et ipse portet, et vobis ${ }^{5}$ portandum offert: sin autem immitis ac superbus est, constat ${ }^{6}$ quia non est de Deo, neque nobis ejus sermo ${ }^{7}$ curandus." ${ }^{8}$ Qui rursus aiebant, "Et unde vel hoc dinoscere valemus?" "Procurate," inquit, "ut ipse prior cum suis ad locum synodi adveniat, et si vobis adpropinquantibus adsurrexerit, scientes ${ }^{4}$ quia famulus Christi est, obtemperanter illum audite: sin autem vos spreverit, nec coram vobis adsurgere voluerit, cum sitis numero plures, et ipse spernatur a vobis." Fecerunt ut dixerat. Factumque est, ut venientibus illis sederet Augustinus in sellā. Quod illi videntes mox in iram conversi sunt, ${ }^{9}$ eumque notantes superbiae, cunctis quae dicebat contradicere laborabant. Dicebat autem eis, "In multis quidem nostrae consuetudini, immo ${ }^{10}$ universalis ecclesiae contraria geritis: et tamen si in tribus his mihi obtemperare vultis; ut Pascha suo tempore celebretis, ut ministerium baptizandi, quo Deo renascimur, juxta morem sanctae Romanae et apostolicae ecclesiaecompleatis, ut genti Anglorum unā nobiscum verbum Domini praedicetis, caetera quae agitis, quamvis moribus nostris contraria, aequanimiter cuncta tolerabimus."

At illi nil horum se facturos, neque illum pro archiepiscopo habituros esse respondebant: conferentes ${ }^{11} \mathrm{ad}$ invicem dicebant, "Si modo nobis adsurgere noluit, quanto magis si ei suhditos esse coeperimus jam nos pro nihilo contemnet."

\section{Hist. Ecc.}

1 praedicaret, I50 (3). 2 absque, 207. ${ }^{3}$ ituri=when they were about to go, or before they went, I79, I83. ${ }^{4}$ quia, II $2-I I 5 . \quad 5$ portandum offert = offers you to carry, I92. ${ }^{6}$ quia, II6. ${ }^{7}$ curandus $=i$ s any heed to be paid, I92. $\quad$ s Qui, 66. 9 eumque notantes superbiae=and censuring him for his pride. $\quad 10$ universalis ecclesiae, understand 'consuetudine.' 11 ad invicem, 70 . 
Adamnan (died $\gamma^{0} 4$ ), ninth abbot of Iona. Famous for his life of Columba the founder of that monastery. This work consists chiefly of a chronicle of the miracles of Columba; but the last chapters which tell the story of his death are so simple and beautiful as to warrant the inclusion of practically the whole of them in this book. The style is barbarous, so much so that a few alterations have been made to bring the more unusual expressions within the comprehension of the student.

\section{De vita et de transitu ad Dominum Sancti Columbae.}

Sanctus Columba, de stirpe nobile ${ }^{1}$ Scoticae gentis ortus, anno aetatis suo quadringesimo secundo pro Christo ${ }^{2}$ peregrinari volens, de ${ }^{3}$ Scotiā in Britanniam demigravit. ${ }^{4}$ Qui ${ }^{5}$ et a puero Christiano deditus ${ }^{6}$ tirocinio et sapientiae studiis, ${ }^{7}$ integritatem corporis et animae puritatem, Deo donante, custodiens, quamvis in terrā positus, caelestibus se moribus aptum ostendebat. Nullum etiam ${ }^{8}$ vel unius horae intervallum transiri poterat, quo non aut orationi ant lectioni ant scripturae aut alicui operi incumberet. ${ }^{9}$ Jejunationum quoque et vigiliarum indefessis laboribus sine ullā intermissione die noctuque occupatus est. Et inter haec omnibus carus, ${ }^{10}$ hilarem semper faciem ostendens, Spiritīs Sancti gaudio intimis laetificabatur ${ }^{11}$ praecordiis. Diu insulam Ionam habitavit quae juxta oras terrae Pictorum in mare sita est, et ibi monasterium collocavit. Tum demum cum jam triginta annos in illā insulā complevisset, illo ipso die, sancta facies ejus mirificā hilaritate effloruit, oculisque ad caelum elevatis, incomparabili repletus gaudio, valde laetificabatur. Tum post modicum intervallum illa suavis laetitia in maestam convertitur tristitiam. At duo viri, qui eādem horā ejus ${ }^{12}$ tugurii ad januam stabant, et ipsi cum eo valde tristificati, causam ipsius subitae laetitiae rogant et illius subsequentis tristitiae. Ad quos sanctus sic profatur "Ite in pace, nec illius laetitiae causam nec etiam tristitiae a me nunc rogate manifestari."

Quo audito, lacrimantes, prostratis in terrā vultibus humiliter rogant, scire volentes aliquid de illā re quae eādem horā sancto erat revelata. " Qui cum eos valde tristes esse vidisset, "Quia vos," ait, "amo, tristificare nolo. Promittere prius debetis ne ulli

${ }_{1}$ Scoticae. The Scotch race then inhabiting Ireland. ${ }^{2}$ peregrinari $=$ to go abroad. $\quad 3$ Scotiā. Ireland was called 'Scotia' in the 6 th cent. $\$$ Qui, 66. ${ }^{5}$ et $=$ even. ${ }^{6}$ tirocinium $=$ service (the state of being a recruit, 'tiro'). 7 integritas $=$ chastity. ${ }^{8}$ vel $=$ even. $\quad$ 'Jejunatio $=$ fasting. $\quad$ " hilaris $=$ cheerful. $\quad 11$ praecordia =heart. $\quad 12$ tugurium $=$ hut. 
hominum 'sacramentum de quo rogatis in vitā meā prodatis." Qui cum secundum ejus mandatum prompte promisissent, vir venerandus sic ad eos proloquitur. "Usque in hunc, inquit, praesentem diem meae in Britanniā peregrinationis triginta completi sunt anni. 'Interea multis ante diebus a Domino meo devote postulavi, ut in fine liujus praesentis anni me de meo absolveret incolatu, et ad caelestem patriam ${ }^{3}$ illico advocaret. Et haec fuit causa meae laetitiae, de quā vos me maesti interrogatis. Angelos enim sanctos de excelso vidi missos throno ad meam de carne animam educendam. Sed ecce nunc subito retardati, ultra nostrae 4 fretum insulae stant in rupe, scilicet volentes, ut me de corpore advocent, adpropinquare. Sed propius accedere non permissi, mox ad caelum redituri sunt; quia Dominus quod mihi totis viribus roganti donavit, ut hāc in die ad ipsum de mundo transirem, multarum magis ecclesiarum pro me orationes audiens, ${ }^{\mathbf{5}}$ dicto citius immutavit. Quibus scilicet ecclesiis exorantibus sic a Domino donatum est ut quatuor ab hāc die mihi in carne manenti superaddantur anni. Haec mihi tam maesta retardatio hodiernae tristitiae ${ }^{6}$ non immerito causa fuit. Quibus quatuor terminatis in hāc vitā annis, Deo propitio, nullā praecedente corporis molestiā, ad Dominum laetus emigrabo." Secundum igitur haec verba, vir venerabilis quatuor postea annos in carne mansit.

Annorum quatuor super memoratorum termino jam appropinquante, ${ }^{7}$ die Sabbati vir sanctus et pius minister ejus Diormitius ad proximum pergunt benedicendum ${ }^{8}$ horreum. Quod intrans Sanctus cum benedixisset, et videns in eo magnos ${ }^{9}$ frugum acervos, "Valde congratulor meis familiaribus monachis, inquit, quia hoc etiam anno, si quidem a vobis emigrare me oportuerit, satis cibi habebitis." Quo audito verbo, Diormitius minister tristificari coepit, et sic locutus est, "Hujus anni tempore, pater, saepius nos contristas, quia de tuo transit ${ }^{10}$ crebro commemoras." Cui Sanctus hoc dedit responsum, "Aliquid ${ }^{11}$ arcanum habeo, quod, si mihi firmiter promiseris, nemini ante meum revelare obitum, de meo tibi transitu aliquid manifestius ${ }^{12}$ intimare potero. Haec in sacris voluminibus dies Sabbatum ${ }^{13}$ nuncupatur, quod interpretatur 're-

1 sacramentum =sacred thing, mystery. 2 Interea mult is ante diebus $=$ For many days past. $\quad 3$ illico= straightway. citius = more quickly than a word can be uttered.

4 fretum =strait. $\quad{ }^{5}$ dicto

6 non immerito $=$ not without good cause. $\quad$ "die Sabbati=Saturday. $\quad{ }^{8}$ horreum $=$ barn. $\quad 9$ frugum acervos =heaps of com. $\quad{ }^{10}$ crebro=frequently. $\quad 11$ arcanum $=$ secret. 12 intimare =to make known. ${ }^{13}$ nuncupare $=$ to call. 
quies.' Et mihi vere est Sabbatum haec hodierna dies, quia hujus praesentis laboriosae vitae mihi ultima est, in quo post meos labores ${ }^{\mathbf{1}}$ sabbatizo, et hāc mediā nocte, ${ }^{2}$ secundum eloquia Scripturarum, patrum gradiar viam. Jam enim Dominus meus Jesus Christus me invitare dignatur; ad quem, inquam, hāc ipsā nocte, ipso me invitante, emigrabo." Haec maesta minister audiens verba, coepit ${ }^{3}$ amare flere. Quem Sanctus ${ }^{4}$ in quantum potuit consolari conabatur.

Post haec Sanctus horreum egreditur, et ad monasterium revertens, mediā residet viā, in quo loco postea crux, ${ }^{5}$ molari infixa lapide, hodieque stans, in margine cernitur viae. Dumque ibidem Sanctus, ut praefatus sum, senio fessus, paululum sedens, requiesceret, ecce albus occurrit ${ }^{6}$ caballus, obediens servitor, qui scilicet ${ }^{7}$ lactaria vascula ad monasterium gestare consueverat. Hic ad Sanctum accidens, ${ }^{8}$ mirum dictu, caput in sinum ejus ponens, dominum a se mox emigraturum, et ipsum ultra non visurum sciens, coepit plangere, ${ }^{9}$ ubertimque, quasi homo, lacrimas in gremium Sancti fundere. Quod videns minister coepit illum lamentatorem repellere. Sed Sanctus prohibuit eum dicens, "Sine hunc, sine nostri amatorem, ut in hunc meum sinum fletūs effundat amarissimi ${ }^{10}$ plangoris. Ecce tu, homo cum sis, et rationalem animam habeas, nullo modo scire de meo exitu potuisti, nisi quod tibi ego ipse nuper manifestavi: huic vero bruto et irrationali ${ }^{11}$ animanti, quoque modo ipse Conditor voluit, egressurum a se dominum manifeste revelavit." Et haec dicens maestum a se revertentem equum benedixit.

Et inde egrediens, et ${ }^{12}$ monticellum monasterio supereminentem ascendens, in vertice ejus paululum stetit, et stans, ambas elevans palmas, suum benedixit ${ }^{\mathbf{1 3}}$ coenobium his verbis, "Huic loco, quamquam angusto et vili, non tantum Scotorum reges, cum populis, sed etiam barbararum et exterarum gentium regnatores cum plebibus sibi subjectis, grandem et non mediocrem conferent honorem: a sanctis quoque etiam aliarum ecclesiarum non mediocris veneratio conferetur."

1 sabbatizare $=$ to rest.

2 secundum eloquia Scripturae $=$ in the words of Scripture. ${ }^{3}$ amare =bitterly. ${ }^{4}$ in quantum potuit $=$ as well as he could . ${ }^{5}$ molari lapide $=$ in a mill-stone. ${ }^{6}$ caballus $=$ horse. The vernacular word; Fr. cheval. ' lactaria vascula $=$ milk-pails. ${ }^{8}$ mirum dictu $=$ wonderful to say, 193. $\quad{ }^{9}$ ubertim =copiously. $\quad{ }^{10}$ plangor =lamentation. $\quad 11$ animans =animal. $\quad{ }^{12}$ monticellum $=a$ little hill. $\quad{ }^{13}$ coenobium $=$ com munity. 


\section{Adamnan}

Post haec verba, de illo descendens monticellulo, et ad monasterium revertens, sedebat in tugurio Psalterium scribens; et ad illum tricesimi tertii psalmi versiculum perveniens ubi scribitur, "Inquirentes autem Dominum non deficient ' omni bono," "Hic," ait, "in fine cessandum est paginae: quae vero sequitur Baithereus scribat." Sancto convenienter congruit "decessori novissimus versus quem scripserit, cui nunquam bona deficient aeterna: successori vero sequens aeque versus congruit, spiritualium doctori filiorum, "Venite, filii, audite me, timorem Domini docebo vos."

Post haec Sanctus ad vespertinalem ${ }^{3}$ Dominicae noctis ${ }^{4}$ missam ingreditur ecclesiam, quā consummatā, ad tugurium revertens in lectulo residet, ubi pro ${ }^{5}$ stramine nudam habebat petram, et pro ${ }^{6}$ pulvillo lapidem, qui hodie juxta sepulcrum ejus stat.

Ibique residens ultima ad fratres mandata, solo audiente ministro, commendat ita loquens, "Haec vobis, O filioli, novissima commendo verba, ut inter vos mutuam et non fictam habeatis caritatem cum pace: et si ita, juxta sanctorum exempla patrum, observaveritis, Deus, confortator bonorum, vobis auxiliabitur, et ego, cum ipso manens, pro vobis interpellabo; et non solum praesentis vitae necessaria ab eo sufficienter administrabuntur, sed etiam aeternalium bonorum praemia, divinorum observatoribus praeparata, tribuentur."

Post quae, felici appropinquante novissimā paulisper horā, Sanctus conticuit. Tum mediā nocte ' festinus surgens ad ecclesiam pergit, citiorque ceteris currens, solus ingressus juxta altare flexis in oratione genibus recumbit; Diormitius minister, tardius prosecutus, eodem momento totam ecclesian angelicā luce repleri videt. Diormitius ergo, ecclesiam ingrediens, flebili ingeminat voce, "Ubi es, pater?" Et, necdum allatis fratrum lucernis, per tenebras ${ }^{8}$ palpans, Sanctum ante altarium recumbantem invenit: quem paululum erigens, et juxta sedens, sanctum in suo gremio posuit caput. Et inter haec ${ }^{9}$ coetus monachorum cum luminaribus accurrens, patre viso moriente, coepit plangere. At Sanctus, necdum egrediente animã, apertis sursum oculis, ad utrumque latus cum mirā vultūs hilaritate et laetitiā circumspiciebat; sanctos scilicet obvios intuens angelos. Diormitius tum sanctam dexteram manum Sancti

1 omni bono, 46, 202. 2 decessori=the departing saint. noctis = Saturday night (the eve of the Lord's day).

3 Dorninicae ${ }^{5}$ stramen $=$ bed. $\quad{ }^{6}$ pulvillum $=$ pillow. ${ }^{7}$ festinus $=$ suddenly. ${ }^{8}$ palpans $==$ feeling. ${ }^{9}$ coetus $=$ crowd. 
ad benedicendum monachorum chorum sublevat. Sed et ipse venerabilis pater in quantum poterat, simul suam movebat manum ut videlicet quod voce in egressu non valebat animae etiam motu manūs fratres videretur benedicere.

Et post sanctam benedictionem ita significatam, continuo spiritum exhalavit. Quo tabernaculo corporis egresso, facies rubens, et mirum in modum angelicā visione ${ }^{1}$ exhilarata remansit, ut non quasi mortui sed dormientis videretur viventis. Tota interea personabat maestis plangoribus ecclesia.

Itaque hymnis matutinalibus terminatis, sacrum corpus de ecclesiā ad tugurium unde paulo ante vivens venerat, cumm ${ }^{2}$ canorā fratrum reportata psalmodiā, et post tres dies sancti et beati patroni venerabile corpus mundis ${ }^{3}$ involutum sindonibus, debitā humatur cum veneratione, in luminosā et a eternali resurrecturum claritudine.

Vita S. Columbae (adapted).

Thomas Aquinas (died I 274), the Angelic Doctor, was the most influential Church writer of the middle ages. He was born of a noble family at Aquino near Naples, joined the Dominican order and was a pupil of Albertus Magnus at Cologne. He taught at Paris, Bologna and Rome and finally settled at Naples. Like the other Schoolmen he devoted his life and writings to the defence of the doctrines of the Church as then understood, following the methods of Aristotle in argument and using the Sentences of Peter the Lombard as the groundwork of his teaching.

He was made a Doctor of the Church by Pius V and his works have been specially commended by Leo XIII to the Catholic seminaries and theological faculties throughout the world.

$\mathrm{He}$ is still studied even by theologians who do not belong to the Roman obedience, while the writings of the other Schoolmen are for the most part neglected and forgotten.

His great worls was the Summa Theologiae and he also compiled a commentary on the Gospels from the writings of the Fathers which goes by the name of the Catena Aurea.

Editions of these works may easily be had. It is doubtful if the pieces that follow were written by him, or not. They are ascribed to him by Hurter in the SS. Patrum Opuscula, and in any case they are interesting examples of mediaeval Latin and of the discussion of subjects that still excite interest.

\footnotetext{
1 exhilaratus $=$ brightened. bus =wrapped in linen.

${ }^{2}$ canorus $=$ tuneful.

3 involutum sindoni-
} 


\section{Thomas Aquinas}

DE BONO FIDEI.

Primum quod est necessarium Christiano est fides, sine quā nullus dicitur fidelis Christianus. Fides autem facit quatuor bona. Primum est ${ }^{\mathbf{1}}$ quod per fidem anima conjungitur Deo: nam per fidem anima Christiana facit quasi quoddam matrimonium cum Deo: "Sponsabo te mili in fide." Et inde est quod quando homo baptizatur, primo confitetur fidem, cum dicitur ei: "Credis in Deum?" quia baptismus est primum sacramentum fidei. Et ideo dicit Dominus: "Qui ${ }^{2}$ crediderit et baptizatus fuerit salvus erit." Baptismus enim sine fide non prodest. Et ideo sciendum est quod nullus est acceptus a Deo sine fide. "Sine fide impossibile est placere Deo." Et ideo dicit Augustinus ${ }^{3}$ super illud, "Omne quod non est ex fide, peccatum est: ubi non est aeternae et incommutabilis veritatis ${ }^{4}$ agnitio, falsa est virtus etiam in optimis moribus."

Secundo quia per fidem incoliatur in nobis vita aeterna: nam vita aeterna nihil aliud est quam cognoscere Deum: unde dicit Dominus: "Haec est vita aeterna, ut cognoscant te solum verum Deum." Haec autem cognitio Dei incipit ${ }^{5}$ hic per fidem, sed perficitur in vitā futurā, in quā cognoscimus eum sicuti est: et idéo dicitur, "Fides est substantia sperandarum rerunı." Nullus ergo potest pervenire ad beatitudinem, quae est vera cognitio Dei, nisi primo cognoscat per fidem. "Beati qui non viderunt, et crediderunt."

Tertio quod fides dirigit vitam praesentem: nam ${ }^{6}$ ad hoc quod homo bene vivat, ${ }^{7}$ oportet quod sciat necessaria ad bene vivendum : et si deberet omnia necessaria ad bene vivendum per studium addiscere, vel non potest pervenire, vel post longum tempus. Fides autem docet omnia necessaria ad bene vivendum. Ipsa enim docet quod est unus Deus, qui est remunerator bonorum et punitor malorum, et quod est alia vita, et ${ }^{8}$ hujusmodi; quibus satis ${ }^{9}$ allicimur ad bonum et vitamus malum. "Justus meus ex fide vivit."

Notice the very frequent use of 'quod' in these selections where 'ut' or an Inf. would be used in Cl. L.

${ }^{1}$ quod =namely that. The clause 'quod... Deo' is the complement of the predicate, ir $6 . \quad{ }^{2}$ crediderit, $88 . \quad{ }^{3}$ super $=$ with reference to the passage, 236. 4 agnitio=recognition. $\quad{ }_{5}^{5}$ hic $=$ here, in this world. ${ }_{6}^{6}$ ad hoc quod homo bene vivat. The clause introd. by 'quod' is in apposition to 'hoc,' I 45 . ${ }^{7}$ oportet quod sciat, II8. ${ }^{8}$ hujusmodi $=$ of such a kind. 9 allicimur $=$ we are enticed. 
Et hoc etiam patet ${ }^{1}$ quia nullus philosophorum ante adventum Christi cum toto conatu suo potuit tantum scire de Deo, et de necessariis ad vitam aeternam, quantum post adventum Christi scit una ${ }^{2}$ vetula per fidem: et ideo dicitur: "repletur est terra scientiā Domini."

Quarto quia fides est quā vincimus tentationes. "Sancti per fidem vincerunt regna." Et hoc patet, ${ }^{1}$ quia omnis tentatio vel est a diabolo, vel a mundo, vel a carne. Diabolus tentat ut non obedias Deo, nec subjiciaris ei. Et hoc per fidem removetur: nam per fidem cognoscimus quod ipse est Dominus omnium, et ideo ${ }^{3}$ sibi est obediendum. "Adversarius vester diabolus circuit quaerens quem devoret: cui resistite fortes in fide." Mundus autem tentat vel alliciendo prosperis, vel terrendo adversis. Sed haec vitamus per fidem, quae facit nos credere aliam vitam meliorem istā: et ideo prospera mundi hujus despicimus, et non formidamus adversa. "Haec est victoria quae vicit mundum, fides nostra": et etiam quia docet nos credere alia majora mala, scilicet inferni. Caro vero tentat inducendo nos ad delectationes vitae praesentis momentaneas. Sed fides ostendit nobis quod per has, si eis ${ }^{4}$ indebite adhaeremus aeternas delectationes amittimus. "In omnibus sumentes scutum fidei." Sic ergo patet quod multum est utile habere fidem. Sed si dicit aliquis: "Stultum est credere quod non videtur, et non sunt credenda quae non videntur," respondeo dicendum quod hoc dubium primo tollit imperfectio intellectūs nostri: nam si homo posset perfecte per se cognoscere omnia visibilia et invisibilia, stultum esset credere quod non videmus; sed cognitio noster est adeo debilis, ${ }^{5}$ quod unus philosophus fuit triginta annis in solitudine, ut cognosceret naturam apis. Si ergo intellectus noster est ita debilis, nonne stultum est nolle credere de Deo nisi illa tantum quae homo posset cognoscere per se? Et ideo contra hoc dicitur: "Ecce Deus magnus, vincens scientiam nostram."

Secundo potest responderi, ${ }^{6}$ quia, ${ }^{7}$ dato quod aliquis magister aliquid diceret in suà scientiā, et aliquis rusticus diceret non esse ita sicut magister doceret, eo quod ipse non intelligeret, multum reputaretur stultus ille rusticus.

1 quia =because. $\quad 2$ vetula = old woman. $\quad{ }^{3}$ sibi, $6 \mathrm{r} . \quad 4$ indebite $=$ excessively. $\quad{ }^{5}$ quod unus philosophus, a curious use of 'quod' in the sense of ' $u$ ' consecutive. $\quad{ }^{6}$ quia, here used to introduce an object clause, I I 2. $\overline{7}$ dato quod aliquis magister aliquid diceret in suā scientiā $=$ let it be granted that any master makes a statement in his own subject, 51 . 


\section{Thomas Aquinas}

Constat autem quod intellectus angeli excedit magis intellectum optimi philosophi, quam intellectus optimi philosophi intellectum rustici. Et ideo stultus est philosophus, si nolit credere ea quae angeli dicunt, et multo magis si nolit credere ea, quae Dens dicit.

Et contra hoc dicitur, "Plurima supra sensum hominum ostensa sunt tibi."

Tertio respondere potest, quia, si homo nollet credere nisi ea, quae cognosceret, certe non posset vivere in hoc mundo. Quomodo etiam aliquis vivere posset nisi crederet aliqui? Quomodo etiam crederet quod talis est pater suus?

Et ideo est necesse quod homo credat alicui de iis, quae perfecte non potest scire per se: sed nulli est credendum sicut Deo; et ideo illi qui non credunt dictis fidei, non sunt sapientes, sed stulti et superbi, sicut dicit Apostolus, "Superbus est, nihil sciens." Propterea dicebat: "Scio cui credidi, et certus sum."

Quarto potest etiam responderi, quia Deus probat quod ea, quae docet fides, sunt vera.

Si enim rex mitteret litteras cum sigillo suo sigillatas, nullus auderet dicere, quod illae litterae non processissent de regis voluntate. Constat autem quod omnia quae sancti crediderunt, et tradiderunt nobis de fide Christi, signata sunt sigillo Dei: quod sigillum ostenderunt illa opera, quae nulla ${ }^{1}$ pura creatura facere potest: et haec sunt miracula, quibus Christus confirmavit dicta apostolorum et sanctorum. Si dicas quod miraculum nullus vidit fieri, respondeo ad hoc: "Constat quod totus mundus colebat idola, et fidem Christi persequebatur, sicut paganorum etiam historiae tradunt. Sed modo omnes conversi sunt ad Christum, et sapientes, et nobiles, et divites, et potentes, et magni ad praedicationem simplicium, et pauperum, et paucorum praedicantium Christum. Aut ergo hoc est miraculose factum, aut non."

Si miraculose, habes propositum. Si non, dico quod non potuit esse majus miraculum quam quod mundus totus sine miraculis converteretur. Non ergo quaerimus aliud. Sic ergo nullus debet dubitare de fide, sed credere ea quae fidei sunt magis quam ea quae videt: quia visus hominis potest decipi, sed Dei scientia nunquam fallitur.

1 pura = mere. 


\section{DE FRUCTIBUS INCARNATIONIS.}

Possumus autem sumere ex his aliqua ad eruditionem. Primo enim confirmatur fides noster. Si enim aliquis diceret aliquid de aliquā terrā remotā, et ipse non fuisset ibi, non crederetur ei sicut si ibi fuisset. Antequam ergo veniret Christus in mundum, patriarchae et prophetae et Johannes Baptista dixerunt aliqua de Deo; sed tamen non ita crediderunt eis homines, sicut Christo, qui fuit cum Deo, imo unum cum ipso: unde multum firma est fides nostra ab ipso Christo nobis tradita. "Deum nemo vidit unquam: unigenitus Filius, qui est in sinu Patris, ipse enarravit." Et inde est quod multa fidei secreta sunt manifesta nobis post adventum Christi, quae ante occulta erant.

Secundo ex iis elevatur spes nostra. Constat enim quod Dei Filius non pro parvo ad nos venit, sumens carnem nostram, sed ${ }^{1}$ pro magnā utilitate nostrā: unde fecit quoddam ${ }^{2}$ commercium scilicet quod assumpsit corpus animatum, et de virgine nasci dignatus est, ut nobis largiretur suam dignitatem: et sic factus est homo, ut hominem faceret Deum. "Per quem habemus accessum per fidem in gratiam istam in quā stamus, et gloriamur in spe gloriae filiorum Dei."

Tertio ex hoc accenditur caritas. Nullum est tam evidens caritatis indicium, quam quod Deus creator omnium factus est creatura, Dominus noster factus est frater noster, Filius Dei factus est filius hominis. "Sic Deus dilexit mundum, ut Filium suum unigenitum daret." Et ideo ex hujus consideratione amor noster "reaccendi debet, et inflammari ad Deum.

Quarto inducimur ad servandam puram animam nostram. In tantum enim natura nostra fuit nobilitata et exaltata ex conjunctione ad Deum, quod fuit ad consortium divinae personae suscepta: unde angelus post incarnationem noluit sustinere quod beatus Johannes adoraret eum, quod ante sustinuerat etiam a maximis patriarchis. Ideo homo hujus exaltationem recolens et attendens, debet ${ }^{4}$ dedignari vilificare se et naturam suam per peccatum: ideo dicit beatus Petrus: "Per quem maxima et pretiosa promissa nobis donavit, ut per haec efficiamur divinae consortes naturae, fugientes ejus quae in mundo est concupiscentiae corruptionem.'

1 pro magnā utilitate nostrā = to our great benefit. nection.
${ }^{3}$ reaccendi=to be kindled afresh. a commercium $=$ con -

4 dedignari =to disdain. 


\section{Thomas Aquinas}

Quinto ex his inflammatur desiderium nostrum ad perveniendum ad Christum. Si enim aliquis rex esset frater alicujus et esset remotus ab eo, desideraret ille, cujus frater esset rex, ad eum venire, et apud eum esse et manere. Unde cum Christus sit frater noster, debemus desiderare esse cum eo et conjugi ei. "Ubicunque fuerit corpus, illuc congregabuntur et aquilae," et Apostolus desiderium habebat dissolvi, et esse cum Christo: quod quidem desiderium crescit in nobis considerando incarnationem ejus.

De Symb. Apost.

\section{QUaRe orare debemus Ut fiat voluntas Dei.}

Sed quid est quod dicitur "Fiat voluntas tua"? Nonne dicitur "Omnia quaecumque voluit fecit"? Si omnia facit quae vult in caelo et in terrā, quid est hoc quod dicit "Fiat voluntas tua sicut in caelo et in terrä"? Ad hoc sciendum est quod Deus tria vult de nobis, et nos petimus ${ }^{1}$ quod haec impleantur.

Primum quidem quod Deus vult de nobis est ${ }^{2}$ quod nos habeamus vitam aeternam. Cum ergo consequimur vitam aeternam, salvamur, et hoc vult Dominus. "Haec est voluntas Patris mei qui misit me, ut omnis qui videt Filium, et credit in eum, habeat vitam aeternam." Haec autem voluntas jam completa est in angelis et in sanctis "qui sunt in patriā, quia vident Deum, et cognoscunt et fruuntur eo. Sed nos desideramus quod sicut voluntas Dei completa est in beatis, ita compleatur in nobis.

Alia voluntas Dei de nobis est, ut servemus mandata ejus. Sic ergo cum dicimus "Fiat voluntas tua," oramus ut impleamus mandata Dei. Haec autem voluntas Dei fit in justis, sed in peccatoribus nondum fit. Notandum est quod ex modo loquendi datur nobis ${ }^{3}$ doctrina. Non enim dicit fac, nec etiam faciamus: sed dicit "Fiat voluntas tua," quia ad vitam aeternam duo sunt necessaria, scilicet gratia Dei et voluntas hominis; et licet Deus fecerit hominem sine homine, non tamen justificat eum sine to. Sic enim dicit Augustinus "Qui creavit te sine te non justificabit te sine te," quia vult quod homo coöperetur. "Convertimini ad me, et ego convertar ad vos."

1 quod haec impleantur: 'quod' is here used as a substitute for 'ut' after a verb of requesting, $\mathbf{1} 42$.

2 quod nos habeamus vitam aeternam, $\mathrm{I}_{45}$.

3 doctrina $=$ teaching. 
“Gratiā Dei sum id quod sum, et gratia ejus in me vacua non fuit." 'Non ergo presumas de te, sed confidas de gratiā Dei; nec negligas, sed adhibeas studium tuum. Et ideo non dicit "faciamus," ne videretur quod nihil faceret gratia Dei; nec dicit "fac," ne videretur quod nihil faceret voluntas et conatus noster: sic dicit “fiat," per gratiam Dei, adhibito studio et conatu nostro.

De Oratione Dominica (adapted).

Thomas a Kempis, who is generally supposed to be the author of the "Imitation of Christ," was a monk in the Augustine convent of Zwolle in the Netherlands in the first half of the I 5 th century. His book is perhaps the most popular devotional treatise in existence. Notice the number of abstract nouns used and their approximation in sense to the words in English derived from them.

\section{Qualiter homo desolatus se Debet in manus Dei offerre.}

Domine Deus, sancte Pater, sis nunc et in aeternum benedictus, quia sicut vis, sic factum est, et quod facis bonum est. Laetetur in te servus tuus, non in se, nec in aliquo alio, quia tu solus laetitia mea. Quid habet servus tuus, nisi quod a te accepit, etiam sine merito suo? Tua sunt omnia, quae dedisti et quae fecisti. Pauper sum et in laboribus a juventute meā, et contristatur anima mea nonnunquam usque ad lacrimas, quandoque etiam conturbatur spiritus meus a se propter imminentes passiones. Pater juste, sancte et semper laudande, venit hora ${ }^{2} u t$ probetur servus tuus. Pater amande, dignum est ut hāc horā patiatur pro te aliquid servus tuus. Pater perpetuo venerande, venit hora, quam ab aeternitate praesciebas affuturum, ${ }^{2}$ ut ad modicum tempus succumbat foris servus tuus, vivat vero semper apud te intus; paululum ${ }^{3}$ vilipendatur, humiliatur et deficiat coram hominibus, passionibus conteratur et languoribus, ut iterum tecum in aurorā novae lucis resurgat et in caelestibus clarificetur. Pater sancte, tu sic ordinasti et sic voluisti; et hoc factum est quod ipse praecepisti.

Haec est enim gratia ad amicum tuum pati et tribulari in mundo pro amore tuo, quotiescumque et a quocumque et quomodocumque id permiseris fieri. Sine consilio et providentiā tuã et sine causā

1 Non presumas, 44. he should be despised.

2 ut probetur, I 47.

3 vilipendatur $=$ that 


\section{Thomas a Kempis}

nihil fit in terrā. Bonum mihi, Domine, quod humiliasti me, ut discam ${ }^{1}$ justificationes tuas, et omnes elationes cordis atque praesumptiones abjiciam.

Utile mihi quod confusio cooperuit faciem meam, ut te potius quam homines ad consolandum requiram. Didici etiam ex hoc inscrutabile judicium tuum expavescere, qui affligis justum cum impio, sed non sine aequitate et justitiā.

Gratias tibi ago, quia non pepercisti malis meis, sed attrivisti me verberibus amaris, infligens dolores et immittens angustias foris et intus. Non est qui me consoletur ex omnibus, quae sub caelo sunt, nisi tu, Domine Deus meus, caelestis medicus animarum, qui percutis et sanas, deducis ad infernos et reducis. Disciplina tua super me, et virga tua me docebit.

Ecce, Pater dilecte, in manibus tuis sum ego, sub virgā correctionis tuae me inclino. Percute dorsum meum et collum meum, ut incurvem ad voluntatem tuam ${ }^{2}$ tortuositatem meam. Fac me pium et humilem discipulum, sicut bene facere consuevisti, ut ambulem ad omnem ${ }^{3}$ nutum tuum. Tibi me et omnia mea ad corrigendum commendo; melius est hic corripi quam in futuro. Tu scis omnia et singula, et nil te latet in humanā conscientiāa Antequam fiunt noscis ventura, et non opus est tibi ut quis te doceat aut admoneat de his, quae geruntur in terrã.

Tu scis quid expedit ad profectum meum, et quantum desaevit tribulatio ad ${ }^{4}$ rubiginem vitiorum purgandam. Fac meum desiderium beneplacitum tuum, et ne despicias peccaminosam vitam meam, nulli melius nec clarius quam tibi notam.

Da mihi, Domine, hoc scire quod sciendum est, hoc amare, quod amandum est, hoc laudare, quod tibi summe placet. Falluntur saepe hominum sensus in judicando; falluntur amatores saeculi visibilia sola amando. Quid est homo inde melior quia reputatur ab homine major?

Fallax fallacem, vanus vanum, caecus caecum, infirmus infirmum decipit, dum exaltat: nam quantum unusquisque est in oculis tuis, tantum est et non amplius, ut ait humilis Sanctus Franciscus.

${ }^{5}$ Fili, non vales semper in ferventiori desiderio virtutum stare, nec in altiori gradu contemplationis consistere; sed necesse habes

1 justificationes=righteousness.

2 tortuositatem $=$ my crooked ways. ${ }^{3}$ nutum $=$ nod, i.e. will. $\quad{ }^{4}$ rutiginem $=$ nust or stain. $\quad{ }^{5}$ Fili, here Christ speaks. 
interdum ob originalem corruptelam ad inferiora descendere, et onus corruptibilis vitae etiam invite et cum taedio portare.

Tunc expedit tibi ad humilia et exteriora opera confugere, et in bonis actibus te recreare, adventum meum et supernam visitationem firmā confidentiā expectare, exilium tuum et ariditatem mentis patienter sufferre, donec a me iterum visiteris et ab omnibus anxietatibus libereris. Nam faciam te laborum oblivisci et internā quiete perfrui. Expandam coram te prata scripturarum, ut dilato corde currere incipies viam mandatorum meorum. Et dices: Non sunt condignae passiones hujus praesentis temporis ad futuram gloriam, quae revelabitur nobis.

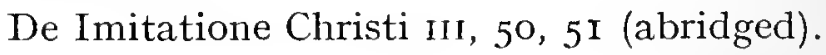




\section{INDEX OF TEXTS QUOTED}

The numbers on the right of each column refer to paragraphs

Genesis

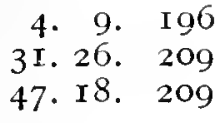

Exodus

6. 3. 233

Deuteronomy

I. 8. 137

4. 2 I. 137

$I$ Kings

I8. 26 . I 50

II Kings

5. 2. IOI

5. 2. 103

Psalms ${ }^{1}$

I. I. 233

5. 8. 233

8. 5. 165

8. 6. 206

9. 4. 189

9. I 8.29

9. 23.67

I8. 468

I8. 11.204

I8. I I. 236

32. 12.58

33. 4. 64

37. 6. 206

39. 5. 68

43. I 7. 206

49. 22. 29

5I. 4. 39

6I. I0. 64

72. 25. 206

72. 27.206

73. 2. 68

73. 6. 64

99. 3. 64
Psalms (cont.)

IOI. 23. I 89

I02. 6. 206

I02. II. 206

102. I3. 29

II2. 2. 64

II3. I I. I 35

I 2 I. 3. 64

I 25. I. I 89

I 37.6 .204

I38. 6. 204

138. 6. 212

I 4 I. 4. I 89

I 45. 5. 68

Proverbs

2I. IO. 29

Isaiah

$$
\text { I. I 4. } 85
$$

6. 4. 47

45. 23. I $37 a$

46. 8. 29

Jeremiah

9. 5. $129 a$

Ezekiel

23. I9. 29

Daniel

4. I7. 67

Hosea

$$
\text { 7. 2. } 29
$$

Amos

9. 8. 185

Wisdom

3. I. 20

I Macc.

7. 38.29
Matthew

I. 21.82

2. I3. 66

2. I3. 9 I

2. 22 . I 39

2. 22. $2 \mathrm{I} 3$

3. I. 54

3. I. 233

3. 7. 142

3. I I. 234

3. I6. 39

3. I6. 123

3. I6. 2 II

4. 3. I 68

4. 6 . $15^{8}$

4. 9. I 72

4. I8. 224

4. 23. 59

4. 24. 37

5. 3. 53

5. 8.56

5. 10. 228

5. I4. 232

5. I6. 208

5. I9. $69 a$

5. 20.87

5. 2 I. I5I

5. 24.82

5. 25.90

5. 28 . I 9 I

5. 34.146

5. 39. I 42

5. 39. I 46

5. 44.2 I 3

6. 5.82

6. 7. 183

6. 7. 233

6. 9. IOI

6. Io. 175

6. I6. 138

6. I9. I 155

6. 27.185

6. 34.234
Matthew (cont.)

7. I. $15^{8}$

7. 4. 98

7. 5. 148

7. 6. 99

7. 7. I 74

7. 9.16

7. II. 6I

7. I2. I 28

7. I5. 206

7. I6. 2 II

7. 19. 74

7. 22. 195

7. 23.65

7. 23.206

7. 25.86

8. I. 2 I I

8. 2. 79

8. 4.99

8. 4. I 42

8. 8. I 47

8. 9. 235

8. $20 . \quad 150$

8. $23.5 \mathrm{I}$

8. 25.74

8. 26.26

8. $27 . \quad$ I 65

8. 29. I62

8. 34 . 5I

9. 4. 69

9. 4. 198

9. 5. 69

9. 9. 53

9. I7. 74

9. $27.5 \mathrm{I}$

9. 33. 5I

9. 36.29

9. $3^{8}$. I $4^{2}$

IO. I. 24

Io. $5 . \quad 99$

ro. 6.84

Iо. Iо. $5^{8}$

IO. I7 206

1 The Psalms are quoted according to the numbering in the Vulgate. 
Matthew (cont.) Matthew (cont.) Matthew (cont.) Mavk (cont.)

10. 24.236

I0. 29.2 I 5

I0. 29.236

ro. 37.204

I0. 42.193

II. I. $\mathrm{I}_{4}$

II. 2. 2 I

II. 3. 78

I I. 3. 102

II. 6.88

II. II. 204

II. I 5. I 87

II. 2 I. 233

II. 26.218

II. 27. 206

12. 24.233

I2. 31. 24

I2. 36.67

I3. I. $23 \mathrm{I}$

I3. I $4 . \mathrm{I}_{5}$

I3. I4. 193

I3. 20.48

I3. 28 . 128

I3. 32. 203

I3. 33. I54

I3. 44.2 I

I3. 48.231

I4. I6. I 47

I 4. 25. 54

I5. 3. 228

I5. 4. 98

I5. 4. 185

I5. I6. 215

I 5. I9. 2 I I

I5. 23. 66

I 5. 23. 229

I6. I3. 88

I6. $2 \mathrm{I} .6 \mathrm{I}$

16. 27.210

17. 22. 192

I8. 7. I 23

I8. 9. 203

ז8. ro. 99

I8. II. 86

I8. I2. 87

I8. 23.2 IO

I8. 27.29

I8. 30.154
I8. $32 . \quad 156$

I8. 33. $\quad 175$

I9. 8.216

I9. I6. 22

I9. 21 . 128

I9. 26.219

20. I. 234

20. 6.55

20. 6.69

20. 6. I9S

20. 21.216

20. 26.223

21. 2. 39

2I. 5. 39

21. 7. 94

21. I9. 231

2I. 3I. 69

2I. 42. 67

2I. 42. 234

21. 43.36

22. IO. 30

22. IO. 49

22. 36.203

23. 3. 230

23. 10. 99

23. 23. II 9

24. 9. 4I

24. 22. 202

24. 29. 229

24. 49. 148

25. 8. 74

25. IO. I 54

25. 19. 22

25. 27. 103

25. 27. I I9

25. $27 . \quad \mathrm{I}_{3}$

25. 35. $\quad 148$

25. 4O. $2 \mathrm{I} 2$

25. 45. 2 I I

26. 8.69

26. 8. 198

26. I2. I 90

26. I3. I 55

26. I 7. I 28

26. I8. 77

26. 24 . I 7 I

26. 3I. 64

26. 32. I 53
26. 33. I 72

26. 33. 233

26. 45.74

26. 53. 195

26. 60. I66

26. 63.227

26. 69. 201

27. 4. 89

27. 4. $\quad 183$

27. 5. $6 \mathrm{I}$

27. 6. 124

27. 7. 234

27 I0. 234

27. 14.216

27. 17.198

27. $21 . \quad 39$

27. 21. 69

27. 29. 211

27. $42 . \quad 77$

27. 44. 64

27. 49. I83

28. 12. $\quad 35$

28. I9. 59

Mark

I. 2. 85

I. 4.26

I. 23.5

2. 2. I 163

2. 4. 214

2. 27.228

3. 5. 236

3. $9 . \quad 142$

3. II. $\quad 53 a$

3. I3. $\mathrm{r} 78$

3. I $5 . \quad$ I 87

3. I5. I9I

4. I. I 28

4. 26. I73

4. $3^{8}$. 125

4. 40.70

4. 40. I65

5. 32. I 62

5. 43 . I 42

6. I6. 67

6. 37.50

6. 37 . IO2

5. $4^{8} \cdot 2,32$
7. I. 45

7. I. 206

7. 30. 232

8. 2. 29

9. I 4.84

9. 22. 98

9. 28.233

10. $32.6 \mathrm{I}$

I I. 22. 24

II. 27.76

I2. 30. 2 I 2

I2. 31.32

I2. 3 I. 82

I2. 3 I. I 75

I3. 8. 227

I4. I. I 43

I 4. 29.166

I 5. 6.128

I 5. 43. 206 I 5. 44. I $4 \mathrm{I}$

Luke

I. $2 \mathrm{I} .90$

I. 42.223

I. $5 \mathrm{I} .6 \mathrm{I}$

I. 59.80

I. 72.210

I. 77.190

$28 . \quad 15$

2. I3. I99

2. I4. 26

2. I 5 . IOI

2. I 5.105

2. IS. 2 II

2. 26 . I 33

2. $3 \mathrm{x} .218$

2. 4 I. 227

2. 47.236

3. $7 . \quad 179$

3. กo. 79

3. I4. IO2

4. Io. 136

4. II. I 36

4. 23.138

4. 25 . I $53 a$

4. 27.235

4. 29.236

4. 36.233 


\section{Index of Texts Quoted}

\begin{tabular}{|c|c|c|c|c|c|c|c|}
\hline Luke (cor & t.) & Luke (con) & t.) & John (cos & t.) & John (cor & t.) \\
\hline 5. 2. & 86 & I 3. I 5. & 42 & 3. 19. & I 45 & 9. 27 . & $7^{8}$ \\
\hline 5. & $\mathrm{I}_{42}$ & I 4.14. & 92 & 3. 23 . & 224 & 9.30. & 64 \\
\hline 5. 4 & I 28 & I5. I6. & 79 & 3. 30 . & I I 8 & 9. 33 . & I 70 \\
\hline 5. 5 . & 227 & I 5. I9. & 147 & 4. 2. & I 66 & 9.35. & 234 \\
\hline 5. 5. & 233 & I 5.32 . & I I9 & 4. 4. & I I9 & 9. 36 . & 60 \\
\hline 5. 8. & I $53 a$ & I6. 9. & $2 \mathrm{II}$ & 4. 9. & $\mathrm{I}_{4} 8$ & I0. 32. & 75 \\
\hline 5. 8 & I 56 & I 7. I 5. & 210 & 4. 34 . & I 45 & IO. 33 . & 2 I I \\
\hline 5. 9. & 233 & I 8. I $_{4}$. & 204 & 4. 40. & I 4 & I I. $2 \mathrm{I}$. & I 69 \\
\hline 5. IO. & 90 & I 8. I 4 . & 206 & 4. 42 . & I 36 & I I. 36. & 79 \\
\hline $5 \cdot 20$ & 66 & I 8.25. & 126 & 4. $45-54$. & I36 & I2. 5 . & $5^{\circ}$ \\
\hline 5. 24 & $\mathrm{I} 47$ & I9. 8. & 77 & 4. 46 . & I3 & I2. 34 . & 60 \\
\hline 6. 6. & I 2 I & 20. 7 & I 34 & 5. I 8. & 62 & I2. 45 . & I 2 \\
\hline 6. 7. & I 44 & 20.20 & I $5^{\circ}$ & 5. 29 . & 26 & I2. $4^{8}$. & I 50 \\
\hline 6. 7 & $I_{4} 8$ & 20. 37 & $23 I$ & 5. 35 . & 60 & I 3.35 . & 70 \\
\hline 7. I 2 . & I $53 a$ & 2 I. 25 & $2 \mathrm{I}_{4}$ & 5.35. & 2 I 6 & I 4.3. & $7^{8}$ \\
\hline 7. I3. & 236 & 21.36. & I 47 & 5.45. & $9 I$ & I 4.5. & I 44 \\
\hline 8. I. & 227 & 22. IO. & 234 & 6. 2. & 236 & I 4.9. & 55 \\
\hline 8. 30. & 40 & 22. I 5 . & I 85 & 6. 6. & $16 I$ & If. I 2. & 32 \\
\hline 8. $3^{8}$. & $2 \mathrm{IO}$ & 22. I9. & 25 & 6. Io. & 98 & I 4. I 8. & I 3 \\
\hline 8. 39. & $I_{44}$ & 22.25 & 30 & 6. I4. & 78 & I 4. 26. & I 6 \\
\hline 8. 42 . & 122 & 22. 34 & I 54 & 6. 28 . & $2 I 6$ & I 4.28. & 169 \\
\hline 8. 42. & I 54 & 22. 49 & 233 & 6. 39. & 145 & I5. 6. & $8_{5}$ \\
\hline 8. 49. & 99 & 22. 50 & 47 & 6. 43. & 70 & I 5.24. & I69 \\
\hline 8. 56. & $69 a$ & 23.14 & I 75 & 6. 45 . & 23 & I6. 2. & 207 \\
\hline 9. 3. & 89 & 23.23. & 48 & 6. 52. & 2 I 3 & I6. 7. & I I I \\
\hline 9. 4 . & 88 & 23.28 & 236 & $6.7 \mathrm{I}$. & $2 \mathrm{I}$ & I6. 7. & 122 \\
\hline 9. 9 . & 60 & 24.23 & I 34 & 7. 8. & 64 & I6. I 2. & 92 \\
\hline 9. 24. & 88 & 24.23 & I 50 & 7. I 7 . & 6 & I6. I9. & 223 \\
\hline 9.25 & 173 & & & 7. I 7 . & I 43 & I6. 32. & I 45 \\
\hline 9. 27 & I 54 & John & & 7.24. & I 5 & 17.2. & 24 \\
\hline 9. 29 & I 54 & I. I. & 2 I9 & 7.29. & 64 & 17.5 & 219 \\
\hline 9. 45. & $2 \mathrm{IS}$ & I. 3 . & 64 & 7.35 . & 26 & I 8. I 6. & 216 \\
\hline 9. 47. & $23 I$ & I. 7. & I $5^{8}$ & 7.35. & I 65 & I8. 20. & I 55 \\
\hline 9.55 & 27 & I. I 4 . & 49 & $7.4 \mathrm{I}$. & I 96 & I 8.30. & 169 \\
\hline IO. $3 \mathrm{I}$. & 122 & I. I 5. & 64 & 7.49. & I 99 & I8. 33 . & 194 \\
\hline IO. 32 . & $23 I$ & I. 26. & 47 & 8. 5 . & $7 \mathrm{I}$ & I 8.34 & I98 \\
\hline IO. 39. & $2.3 \mathrm{I}$ & I. 27. & 147 & 8. 9. & 229 & I 8.35 & I96 \\
\hline IO. 40. & 220 & I. $3^{8}$ & 66 & 8. I3. & 64 & I 8.36 . & 2 I I \\
\hline IO. $4 \mathrm{I}$. & 222 & I. 44 . & 206 & 8. I6. & I 68 & Ig. I I. & I 69 \\
\hline II. I 8. & I 33 & I. $4^{8}$. & I 54 & 8. 23. & 64 & I9. 25. & $2 \mathrm{I}$ \\
\hline I 2.24. & 28 & 2. I 7 . & 24 & 8. 50. & I $5^{\circ}$ & I9. 25. & 224 \\
\hline I 2.44 . & 232 & 2. 20 . & 55 & 9. 4. & I 53 & 21.23 & 77 \\
\hline I 2.45 . & $2 \mathrm{I} 4$ & 2. 24 . & I 56 & 9. 8 . & 60 & & \\
\hline I2. 47 . & 230 & 3. 4. & 128 & 9. I 2. & 60 & $A c t s$ & \\
\hline I2. 50. & 92 & 3. 4. & I $53 a$ & 9. I 8. & 60 & I. & 126 \\
\hline I 3.2. & 204 & 3. 7. & 99 & 9. $2 \mathrm{I}$. & 60 & I. & $3 I$ \\
\hline I3. 2. & $2 \mathrm{I}+$ & 3. 7. & I 4 I & 9. $2 \mathrm{I}$. & I 44 & I. 9 & $5 I$ \\
\hline I3. 4 . & 226 & 3. I6. & I 63 & 9. 25. & I 66 & 2. 6 . & I $3^{8}$ \\
\hline
\end{tabular}




\section{Index of Texts Quoted}

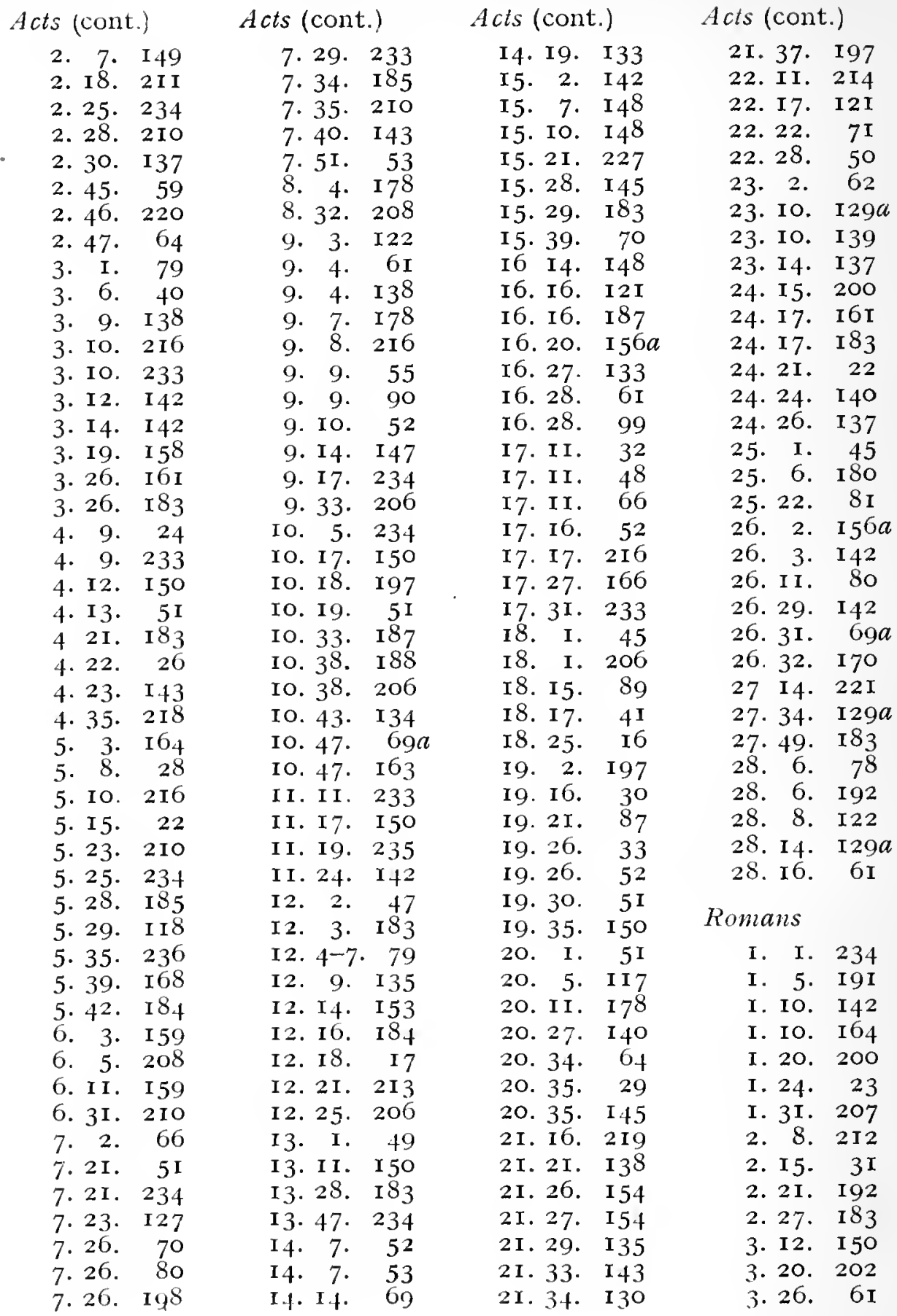




\section{Index of Texts Quoted}

Romans (cont.)

3. 28 . 2 I 5

3. 29. 195

4. 2. 168

4. I4. $2 \mathrm{I} 2$

5. 7. $69 a$

5. 7. I03

6. 3. I95

6. 3. 233

6. 4. I 75

7. 8. I $7 \mathbf{I}$

7. I8. I 29

8. 3. 2 II

8. I3. 230

8. 27.230

8. 35.23

8. 36.26

9. 3. $8 \mathrm{I}$

9. 24. 59

Io. 2. 24

10. Io. 216

IO. I8. I 95

II. 3 I. 25

II. 3I. 234

I2. 3. $\mathrm{I}_{42}$

I2. I 5. I46

I2. I6. 64

I2. I6, 70

I2. $20 . \quad 183$

I3. II. I 47

I 4. I. 233

I 4. 9.30

I 4. I I. I37 $a$

I 4. I 3.70

I 4. 22. 225

I5. 3. 37

I5. 4. 25

I5. 5. 26

I5. 5. 70

I5. 8. 24

I5. 8. I60

I5. 8.190

I5. 9.236

I5. I 3 I 87

I 5. I6. 233

I 5. 22. I 40

I5. 24. 88

I5. 26.22

I6. I6. 70
Romans (cont.)

I6. I7. 226

I6. I 8.37

I6. I 8. 7 I

I Corinthians

I. 4. 2 I 3

I. 4. 233

I. IO. 64

I. I7. I62

I. 29.202

2. I. 233

2. I3. 23

2. I6. I 50

3. II. 226

3. I5. 227

3. $17 . \quad 172$

3. 20. I 35

4. 2. $69 a$

4. 2. 127

4. 8. IOI

4. I4. 105

5. II. I 42

6. I. 2 I 9

6. 2. 150

6. 2. 195

6. 12. 235

7. 5. 64

7. 8. I 73

7. I0. I 42

7. 25. I 75

7. $28 . \quad 7 \mathbf{I}$

7. $28 . \quad 75$

7. 29. I 26

9. 7. I 75

9. 15. 57

9. I 5. I 26

9. I9. I66

9. 20. I 75

9. 27 . I $53 a$

I0. 29. 69

I0. 29 . 198

I2. 24 . I87

I3. I3. 203

I 4. 20. 53

I 4. 39. I 40

I4. 39. I 42

I5. 8.42

I 5. I 2. I35
I Cor. (cont.)

I 5. I 5. 2 I 7

I 5. 27.226

I 5. 29. 2 I 3

I5. 3I. 25

I5. 32. 37

I 5. $33 . \quad 74$

II Corinthians

2. I2. 228

2. 17.90

5. 8. I 47

5. 8. 216

5. I 4.23

5. 20. 57

7. 8.216

9. 8. I 47

I0. 2. I $29 a$

IO. 5.24

I0. 9. I $29 a$

IO. I $5.3 \mathrm{I}$

I I. 26. 2 I

I I. 28,226

I2. $5 . \quad 7 \mathrm{I}$

I 2. I I. 204

I2. II. 206

I2. II. 2 I 8

Galatians

I. 8. $\mathbf{I} 66$

I. I0. 169

I. I 4.232

I. I 5.124

I. I 7.25

I. 23.93

2. $6 . \quad 125$

3. I. I64

3. 5. 193

3. II. $2 \mathrm{I} 2$

4. 4. I 53

4. 20. 103

5. 4. 75

5. II. 2 I

5. $237 \mathrm{I}$

6. 9. I83

Ephesians

I. I6. I 84

2. 14.178
Eph. (cont.)

2. $15 . \quad 178$

4. 28.79

4. 28.99

4. 29. 100

4. 29. 202

4. 32. 70

5. 2. 26

5. 28 . I 75

5. 32.233

6. 7.210

6. II. I 7

6. I $4 . \quad$ I 8

6. $2 \mathrm{I}, 220$

Philippians

I. I8. 82

2. I2. 62

2. I9. I 37

2. 20 . I 50

2. 30.222

3. 4. I 66

3. 2 I. 26

4. 2. $I_{42}$

Colossians

I. 9. I $_{4}$

I. $29 . \quad$ I 88

2. 5. I66

2. I2. 24

2. 23.216

3. $9 . \quad \mathrm{I} 7$

3. $2 \mathrm{I} . \quad 5^{6}$

4. 2. $4 \mathrm{I}$

4. 3. 105

4. 6. 148

4. I6. 219

I Thessalonians

$\therefore 8.123$

I. 9. I64

2. $7.4 \mathrm{I}$

2. 7. I 66

2. I3. 65

3. I. I 24

3. 5. I 60

3. 5. I 90

4. I3. I82 
I Thess. (cont.) Titus
4. I6. 233
5. S. $I_{7}$
3. I. $\mathrm{I}+2$

II Thessalonians

$\begin{array}{rrr}\text { 2. } & 4 . & 175 \\ 2 . & 8 . & 68 \\ \text { 3. } & \text { I3. } & 184\end{array}$

I Timothy

I. 9. 220

2. $8 . \quad 128$

3. 5. 24

4. I. 23

4. I 4 . 210

5. 19. 235

5. 20. 208

5. $2 \mathrm{I} . \mathrm{I} 87$

6. $5.44^{6}$

6. I 2. I 5

6. 13.235

\section{Timothy}

I. I 2. 147

I. I 7. I 3

2. 2. 147

2. I I. I 72

4. 3. 53

4. 3. 216

4. 7. 15

4. 7.84

4. I 8.234
Hebrews

2. 6.165

2. 7. 204

2. 7.206

3. 3. 32

3. $3 . \quad 5^{8}$

3. 3. 204

3. 3. 214

3. II. I $37 a$

3. 18 . I 37

4. II. 64

4. I 5.207

4. I 5.213

4. I 5.227

5. 5. 148

6. 10. 29

b. Io. $\mathrm{I}_{4} 8$

6. 13. I $37 a$

6. I4. I 85

อ. I6. 32

7. 5. 166

7. I2. 123

7. 14. 233

7. 26. 123

8. 3. I 23

9. 3. 229

9. 9. 188

9. I6. I 23
+. 7. 188
Hebrews (cont.) I Peter (cont.)

I0. 22. I8

IO. 3I. I92

II. 4. 203

II. $6 . \quad$ I 35

II. 8 . I 48

I3. 2. 29

I3. 8. 64

I3. I9. I 42

James

4. I4. 233

5. 8. 150

II Peter

I. I9. 183

2. 10.229

3. $5 . \quad \mathrm{I} 25$

I John

I. 9. I63

2. $27 . \quad 147$

3. $\mathrm{I}_{3} \cdot \mathrm{I}_{4} \mathrm{I}$

4. 20.136

2. I $8.2 \mathrm{I} 5$

3. 4. 47

3. 4. I 66

III John

3. 4. 206

3. 8. 199

3. I0. 64

3. I4. 2I 7

5. I3. I74

5. I4. $69 a$

5. 16. 70

I Peter

I. 24.85

2. II. I 42

3. I4. I 5

4. 4. 5 I

4. 7.85

4. I 2. 175
I. $4 . \quad 32$

Revelation

I. I I. 43

3. 3. 59

3. $9 . \quad \mathrm{I} 42$

3. I5. IOI

3. 17.57

7. 9. 199

II. I8. I 47

I3. 5. I 47

I6. II. 2 I 4

I 8. 4. I99

I 8. 22. 202

21. 23. 57 



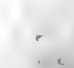

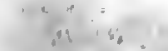

$1+1$
$1+1$

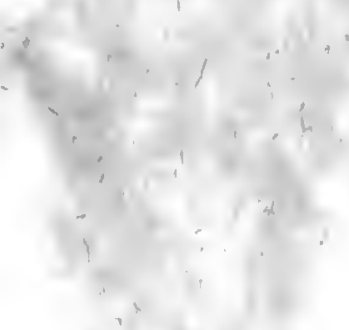

+.

$\therefore$

.

+

$+\ldots+1,+\cdots$

$+\frac{1}{2+\infty}+\cdots$

a.

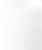

$$
+2
$$

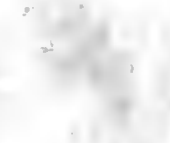

$+$
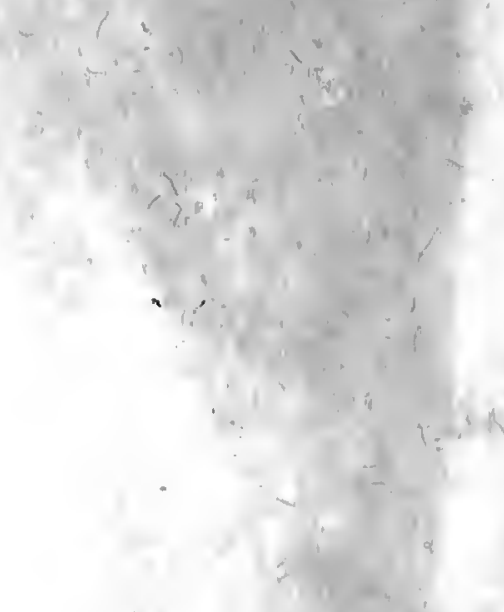

and if

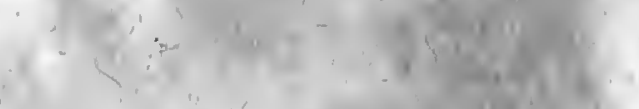

.4

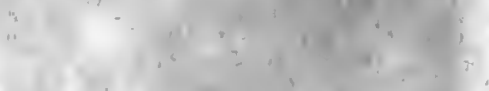

$+4+1$ 
PA $2823 \quad$ N8 1922

SMC

Nunn, H. P. V. (Henry

Preston Vaughan)

An introduction to

ecclesiastical Latin/

i)

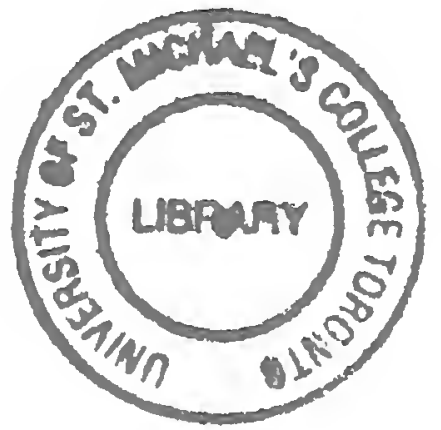


